\title{
MULTIDRUG RESISTANCE REVERSING ACTIVITY OF ORGANOSELENIUM COMPOUNDS
}

\author{
Ph.D. Thesis
}

Márió Gajdács, Pharm.D.

Supervisor: Gabriella Spengler, Ph.D.

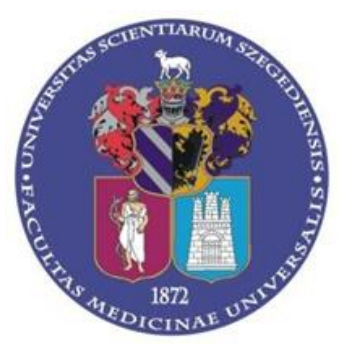

Department of Medical Microbiology and Immunobiology

Faculty of Medicine

University of Szeged

Szeged

2018 


\section{CONTENTS}

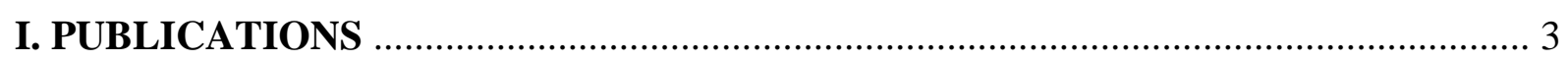

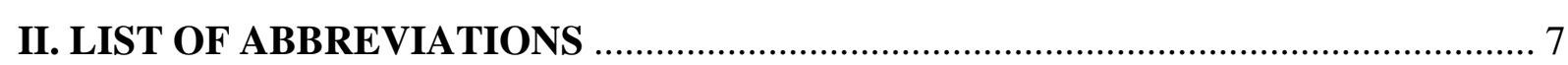

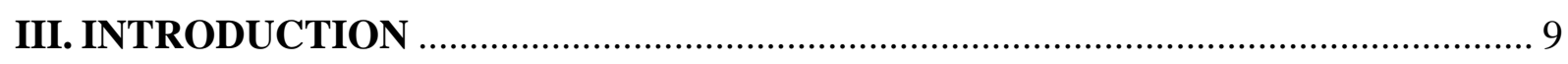

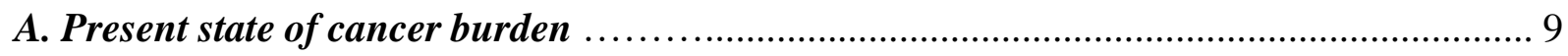

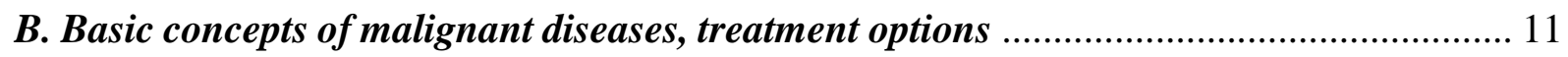

C. Mechanisms of multidrug resistance (MDR) in cancer cells ......................................... 14

a. Efflux pump mediated drug resistance, $A B C$ transporters............................................... 15

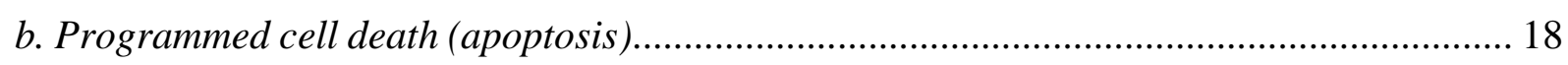

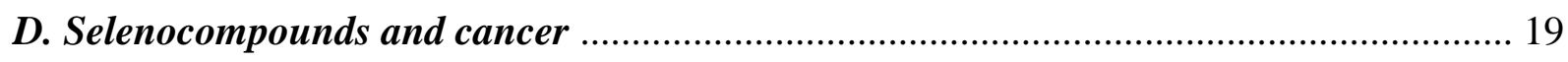

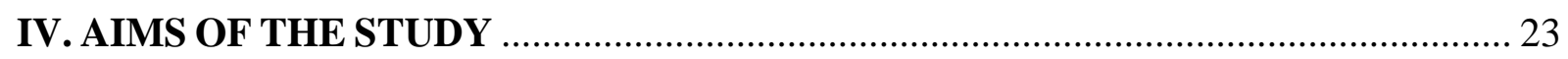

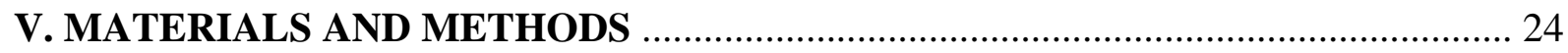

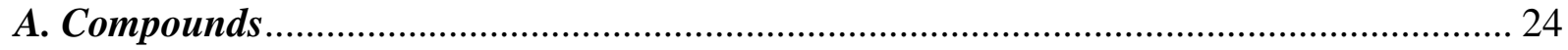

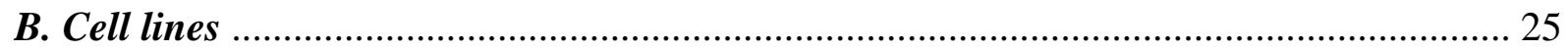

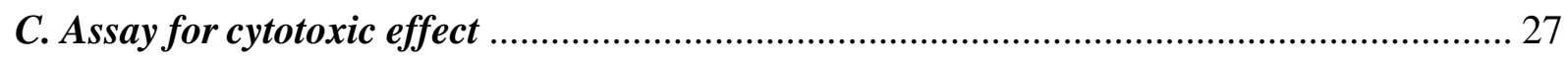

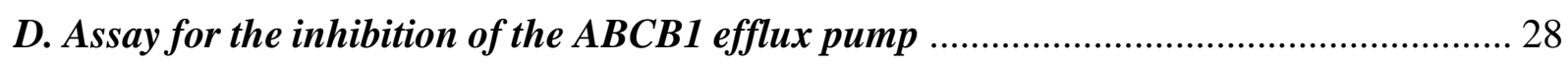

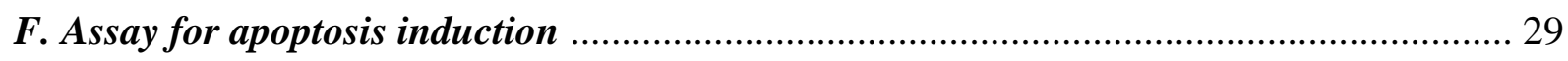

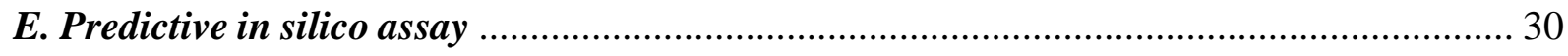

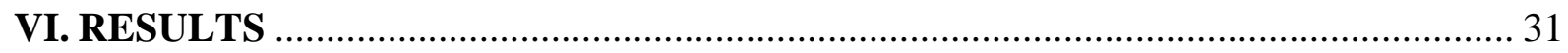

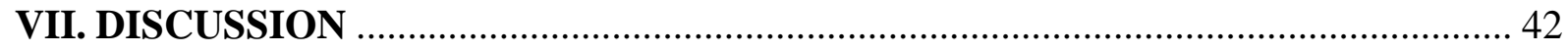

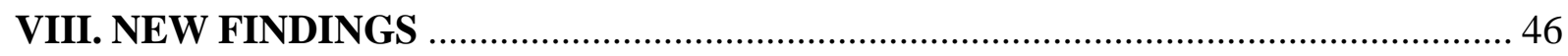

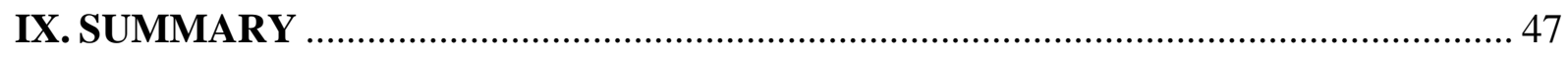

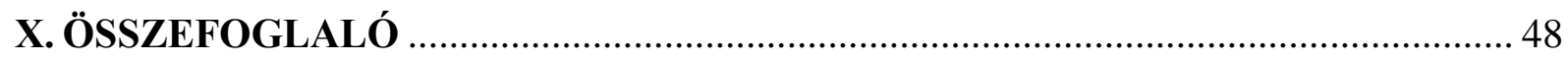

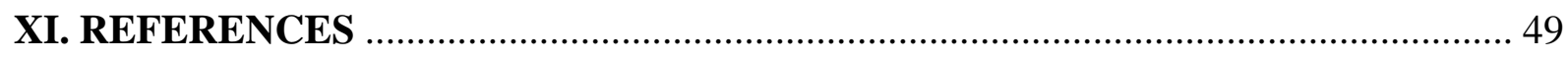

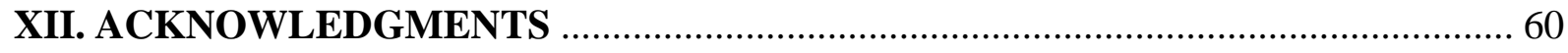

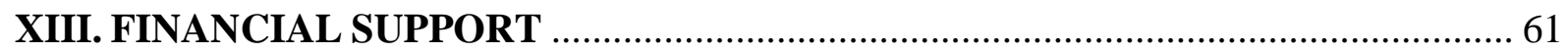

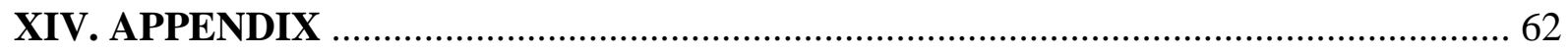

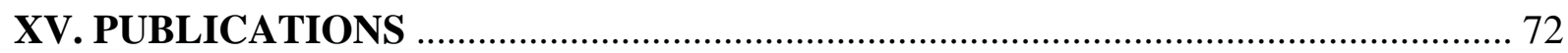




\section{PUBLICATIONS}

\section{Publications related to the subject of the thesis}

I. Domínguez-Álvarez E, Gajdács M, Spengler G, Palop JA, Marć MA, Kieć-Kononowicz $\mathrm{K}$, Amaral L, Molnár J, Jacob C, Handzlik J, Sanmartín C: Identification of selenocompounds with promising properties to reverse cancer multidrug resistance. Bioorganic and Medicinal Chemistry Letters 26(12): 2821-2824, 2016.

IF 2016: 2.454, Citations: 12 (Independent citations: 5)

II. Gajdács M, Spengler G, Sanmartín C, Marć MA, Handzlik J, Domínguez-Álvarez E: Selenoesters and selenoanhydrides as novel multidrug resistance reversing agents: A confirmation study in a colon cancer MDR cell line. Bioorganic and Medicinal Chemistry Letters 27(4): 797-802, 2017.

IF 2017: 2.442, Citations: 10 (Independent citations: 4)

III. Gajdács M, Handzlik J, Sanmartín C, Domínguez-Álvarez E, Spengler G: [Organoselenium compounds as antitumor agents: in vitro evaluation on a colon cancer model system] (article in Hungarian). Acta Pharmaceutica Hungarica 88(2): 59-66, 2018. IF 2017: -, Citations: -

IV. Gajdács M, Handzlik J, Sanmartín C, Domínguez-Álvarez E, Spengler G: [Prediction of ADME properties for selenocompounds with anticancer and efflux pump inhibitory activity using preliminary computational methods] (article in Hungarian). Acta Pharmaceutica Hungarica 88(2): 67-74, 2018.

IF 2017: -, Citations: -

$\Sigma I F: 4.896$ 


\section{Publications not related to the subject of the thesis}

I. Takács D, Csonka Á, Horváth Á, Windt T, Gajdács M, Riedl Zs, Hajós Gy, Amaral L, Molnár J, Spengler G: Reversal of ABCB1 related multidrug resistance of colon adenocarcinoma cells by phenothiazines. Anticancer Research 35(6): 3245-3252, 2015.

IF 2015: 1.895, Citations: 11 (Independent citations: 7)

II. Spengler G, Kincses A, Gajdács M, Amaral L: New roads leading to old destinations: Efflux pumps as targets to reverse multidrug resistance in bacteria. Molecules 22(3): Paper 468, 2017.

IF 2017: 3.098, Citations: 28 (Independent citations: 24)

III. Gajdács M, Spengler G, Urbán E: Identification and antimicrobial susceptibility testing of anaerobic bacteria: Rubik's Cube of clinical microbiology? Antibiotics 6(4): Paper 25, 2017.

IF 2017: -, Citations: 13 (Independent citations: 12)

IV. Magyari J, Barta Holló B, Vojinović-Ješić LS, Radanović MM, Armaković S, Armaković SJ, Molnár J, Kincses A, Gajdács M, Spengler G, Mészáros Szécsényi K: Interactions of Schiff base type compounds and their coordination complexes with the anticancer drug cisplatin. New Journal of Chemistry 42(8): 5834-5843, 2018.

IF 2017: 3.201, Citations: 1 (Independent citations: 1)

V. Bourichi S, Mishbahi H, Rodi KY, Chahdi FO, Essassi EM, Szabó S, Szalontai B, Gajdács M, Molnár J, Spengler G: In vitro evaluation of the multidrug resistance reversing activity of novel imidazo[4,5-b]pyridine derivatives. Anticancer Research 38(7): 3999-4003, 2018. IF 2017: 1.937, Citations: 1

VI. Ferreira R, Kincses A, Gajdács M, Spengler G, dos Santos D, Molnár J, Ferreira MJ: Terpenoids from Euphorbia pedroi as multidrug resistance reversers. Journal of Natural Products 81(9): 2032-2040.

IF 2017: 3.885, Citations: -

V. Gajdács M, Paulik E, Szabó A: [The opinions of community pharmacists related to antibiotic use and resistance] (article in Hungarian). Acta Pharmaceutica Hungarica, accepted.

IF 2017: -, Citations: -

VII. Gajdács M: Chapter 12. Open Research: Past, Present, and Future. The 2018 MDPI Writing Prize Book: Global benefits of Open Research 33-35. (book chapter)

IF 2017: -, Citations: -

EIF: 14.016

Cumulative IF: 18.912

Citations: 76 


\section{Presentations related to the subject of the thesis}

I. Gajdács M: Szelénészter-származékok rákellenes hatásának vizsgálata. $22^{\text {nd }}$ Student's Scientific Conference in Târgu Mureș. Târgu Mureș, Romania, 25-28 $8^{\text {th }}$ of March 2015 (oral presentation in Hungarian)

II. Gajdács M: Anticancer activity of selenoester derivatives. $7^{\text {th }}$ International Student Medical Congress in Košice. Košice, Slovakia. 24-26 $6^{\text {th }}$ of June 2015 (oral presentation in English)

III. Gajdács M, Domínguez-Álvarez E, Handzlik J, Burián K, Spengler G: Reversal of multidrug resistance by selenoester derivatives. $17^{\text {th }}$ International Congress of the Hungarian Society for Microbiology. Budapest, Hungary, 7-10 ${ }^{\text {th }}$ of July 2015 (oral presentation in English)

IV. Gajdács M: Selenoester derivatives as potential agents in MDR cancer. $10^{\text {th }}$ International Medical Students' Congress. Novi Sad, Serbia, 16-19 ${ }^{\text {th }}$ of July 2015 (oral presentation in English)

V. Gajdács M: Selenium-based compounds as promising anticancer agents. $21^{\text {st }}$ Korányi Frigyes Scientific Forum. Budapest, Hungary, 10-11 th of March 2016 (oral presentation in English)

VI. Gajdács M: Rákellenes hatású szelenoészterek vizsgálata in vitro és in silico módszerekkel. 23 ${ }^{\text {rd }}$ Student's Scientific Conference in Târgu Mureș. Târgu Mureș, Romania, 6-9 ${ }^{\text {th }}$ of April 2016 (oral presentation in Hungarian)

VII. Gajdács M: Comprehensive evaluation of selenoester derivatives as anticancer agents. Spring Wind 2016 Multidisciplinary Conference. Budapest, Hungary, 15-17 ${ }^{\text {th }}$ of April 2016 (oral presentation in English)

VIII. Gajdács M, Domínguez-Álvarez E, Handzlik J, Sanmartín C, Spengler G: Evaluation of selenoester derivatives with potential efflux pump inhibiting and apoptosis inducing properties on cancer cells. The meeting of "Bio-Selenium People in Europe". Kraków, Poland, 1-3 ${ }^{\text {rd }}$ of September 2016 (oral presentation in English)

IX. Domínguez-Álvarez E, Gajdács M, Prior C, Palop JA, Plano D, Sanmartín C, Witek K, Marć MA, Latacz G, Kieć-Kononowicz K, Handzlik J, Jacob C, Spengler G: An overview of the different biological activities shown by selenoesters and selenoanhydrides. The meeting of "Bio-Selenium People in Europe". Kraków, Poland, 1-3 ${ }^{\text {rd }}$ of September 2016 (oral presentation in English) 
X. Gajdács M, Domínguez-Álvarez E, Handzlik J, Spengler G: Redox-aktív szerves szelénvegyületek antitumor hatásának vizsgálata. $39^{\text {th }}$ Days of Lecturers in Chemistry. Szeged, Hungary, $17-19^{\text {th }}$ of October 2016 (oral presentation in Hungarian)

XI. Gajdács M, Domínguez-Álvarez E, Handzlik J, Spengler G: Rákellenes hatású szerves szelénvegyületek aktivitásának vizsgálata kombinációs kemoterápiában. PhD Conference of the Hungarian Ministry of Foreign Affairs and Trade. Szeged, Hungary, 3-4 ${ }^{\text {th }}$ of March 2017 (oral presentation in Hungarian)

XII. Gajdács M, Domínguez-Álvarez E, Handzlik J, Spengler G: Szelenoanhidrid és szelenoészter típusú vegyületek multidrug rezisztencia visszafordító hatása vastagbél adenokarcinóma sejteken. Spring Wind 2017 Multidisciplinary Conference. Miskolc, Hungary, $31^{\text {st }}$ of March-2 $2^{\text {nd }}$ of April 2017 (oral presentation in Hungarian)

XIII. Gajdács M, Handzlik J, Sanmartín C, Domínguez-Álvarez E, Spengler G: Selenocompounds as combinational agents in cancer chemotherapy: An in vitro perspective. $19^{\text {th }}$ Danube-Kris-Mures-Tisa (DKMT) Euroregional Conference on Environment and Health. Szeged, Hungary, 9-10 $0^{\text {th }}$ of June 2017 (poster presentation in English)

XIV. Gajdács M, Handzlik J, Sanmartín C, Domínguez-Álvarez E, Spengler G: Rákellenes hatású szelenoészterek a kombinációs kemoterápiában. DKK17: Congress of graduate students in clinical studies. Pécs, Hungary, $28^{\text {th }}$ of October 2017 (oral presentation in Hungarian)

XV. Gajdács M: Szerves szelénvegyületek jelentősége a kísérletes kemoterápiás kutatásokban. Annual Szent-Györgyi Days at the University of Szeged. Szeged, Hungary $24^{\text {th }}$ of November 2017 (oral presentation in Hungarian)

XVI. Gajdács M, Domínguez-Álvarez E, Spengler G: Antitumor activity of organoselenium compounds against specific tumor types with significant mortality in Hungary. Spring Wind 2018 Multidisciplinary Conference. Györ, Hungary, 4-6 $6^{\text {th }}$ of May 2018 (oral presentation in English)

XVII. Gajdács M: Szerves szelénvegyületek (további) biológiai hatásának vizsgálata. Closing Conference of the Márton Áron Research Programme of the Hungarian Ministry of Foreign Affairs and Trade. Budapest, Hungary, 8- $9^{\text {th }}$ of June 2018 (oral presentation in Hungarian)

Number of presentations related to the subject of the thesis: 17 


\section{LIST OF ABBREVIATIONS}

$\AA \quad$ ảngström

ABC ATP-binding cassette

ADME absorption, distribution, metabolism, excretion

ALE average life expectancy

ATP adenosine triphosphate

$B C l$-2 B-cell lymphoma-2 gene

$B R C A$ breast cancer susceptibility gene

BRCP breast cancer resistance protein

CAR chimeric antigen receptor

Cdk-i cycline-dependent kinase inhibitor

CNS central nervous system

CR complete remission

DDR DNA damage response

DLT dose-limiting toxicity

DNA deoxyribonucleic acid

DMSO dimethyl sulfoxide

EBV Epstein-Barr virus

EDTA ethylenediaminetetraacetic acid

EPI efflux pump inhibitor

ER endoplasmic reticulum

EU European Union

FAR fluorescence activity ratio

FADD Fas-associated death domain

FBS foetal bovine serum

FDA Food and Drug Administration of the United States

FITC fluorescein isothiocyanate

FL-1 mean fluorescence

FSC forward scatter count

GPx glutathione peroxidase

HBV hepatitis B virus

$\mathrm{HCV}$ hepatitis $\mathrm{C}$ virus

$\mathrm{HCl}$ hydrochloric acid

HEPES 4-(2-hydroxyethyl)-1-piperazine ethanesulfonic acid

HIA human intestinal absorption

HIV human immunodeficiency virus

HPV human papilloma virus

HTLV human T-lymphotropic virus

M molecular weight

MDCK Madin-Darby canine kidney epithelial cell line

MDR multidrug resistance

MRP multidrug resistance protein 
MS mass spectrometry

MTT 3-(4,5-dimethylthiazol-2-yl)-2,5-diphenyltetrazolium bromide

M627 12H-benzo[ $\alpha]$ phenothiazine

NBD nucleotide binding domain

NEAA non-essential amino acid

NMR nuclear magnetic resonance

OD optical density

PAR parental

PARP poly(ADP-ribose)polymerase

PBS phosphate-buffered saline

PI propidium iodide

PPB plasma protein binding

PR partial remission

PS phosphatidyl serine

p53 tumor suppressor protein p53

QoL quality of life

$\mathrm{R}^{2} \quad$ coefficient of determination

ROS reactive oxygen species

RO5 (Lipinsky's) Rule of Five

RSeS reactive selenium species

R123 rhodamine 123

SAR structure-activity relationship

SD standard deviation

SDS sodium dodecyl sulphate

Se selenium

SeNP selenium nanoparticles

SI selectivity index

SSC side scatter count

Te tellurium

TKI tyrosine kinase inhibitor

TM transmembrane domain

TNF tumor necrosis factor

TPSA topological polar surface area

TRAF2 TNF receptor-associated factor 2

TRAIL TNF-related apoptosis-inducing ligand

U international unit

WHO World Health Organization

YPPL years of potential life lost 


\section{INTRODUCTION}

\section{A. Present state of cancer burden}

Cancer-related mortality is the second major cause of death and principal factor in years of potential life lost (YPPL) among the 18-64 years old population, posing as a significant public health burden worldwide (Figure 1.) [1-3]. In 2012, cancer accounted for 8.2 million deaths and 14.1 million new cancer cases across the globe, while 32.6 million people entered the period of 5-year remission (partial or complete) [4-6]. This means that one out of six deaths was associated with cancer. Based on the estimates of the World Health Organization (WHO), the incidence of malignant diseases will increase $50 \%$ by 2030 and it is expected that cancer will surpass cardiovascular illnesses as the leading causes of mortality [6]. Malignant diseases have a considerable economic impact on the healthcare infrastructure: in 2010 the economic costs of cancer were estimated to be around 1 trillion euros $[7,8]$.

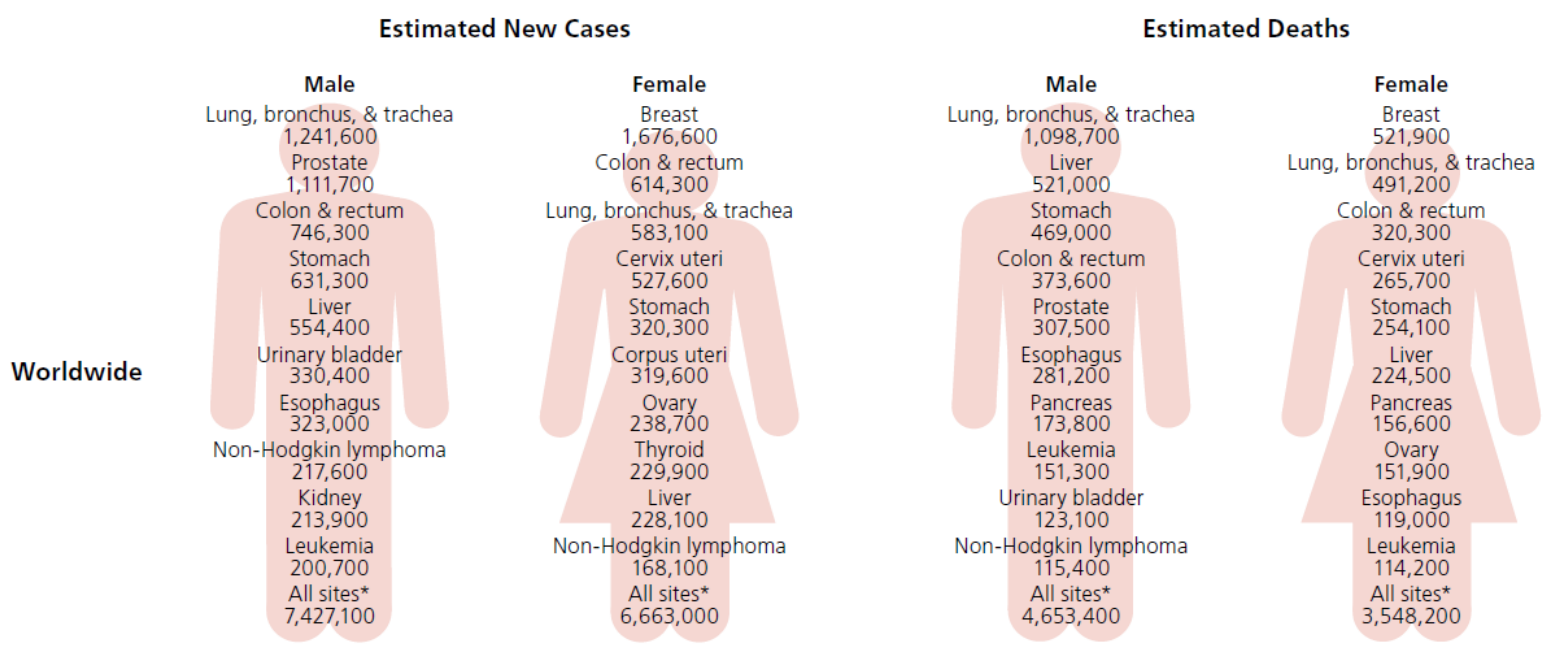

Figure 1. Estimated new cancer cases and deaths for various types of cancer with significant mortality worldwide, 2012 [6]

Colorectal cancer is the third most common cancer in men and the second in women, with an estimated 1.4 million new cases worldwide in 2012 [4]. The highest incidence rates were observed in developed countries, such as the United States, Australia, members of the European Union and South Korea, and the incidence of colorectal cancer is steadily increasing, even in countries, where risk was historically low (e.g., Japan) [6]. About 693,900 deaths occurred in 2012 from colorectal cancer, accounting for $8 \%$ of all cancer deaths [9].

An estimated 1.8 million new cases and 1.6 million deaths (around 70\% male) were associated with lung cancer in 2012 (about 13\% of overall cancer diagnoses), the highest incidence rates were in Northern America, Europe, Eastern Asia, Uruguay and China for both males and females [2,6]. Lung cancer is the leading cause of cancer death in men and the second leading cause in women (although in some countries, lung cancer deaths surpass breast cancer mortality) [10]. 


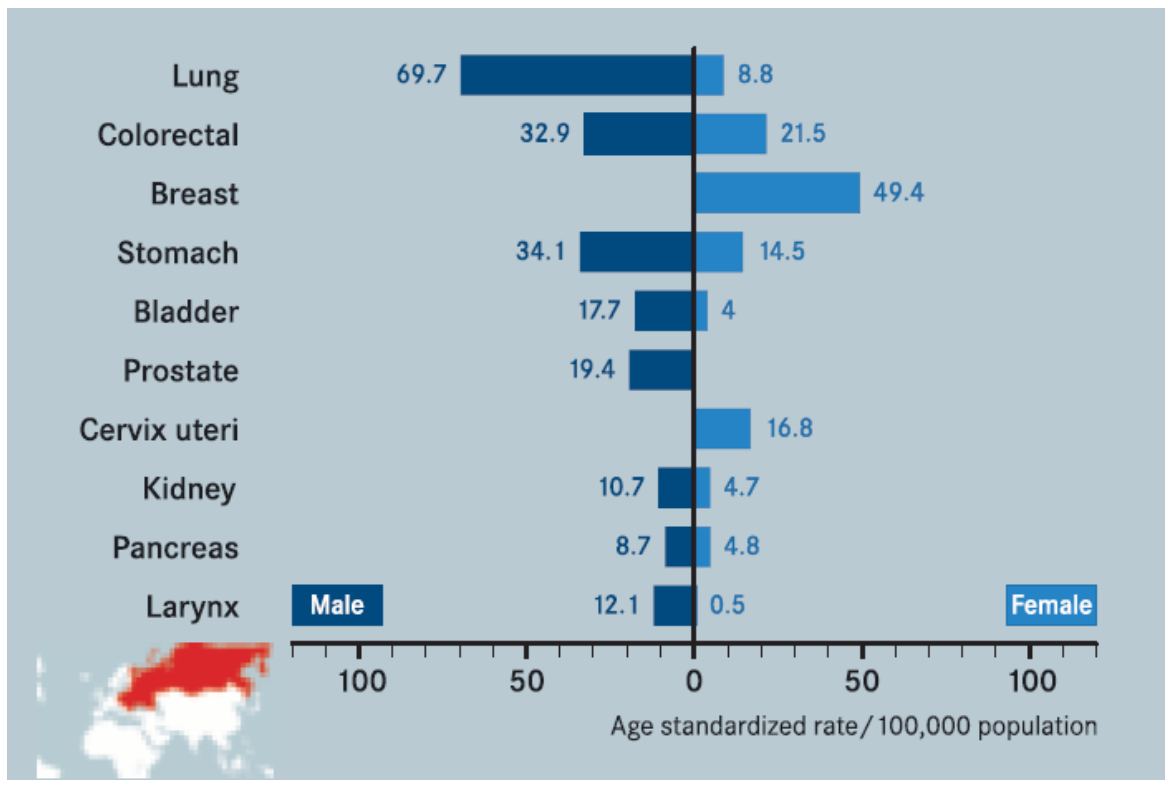

Figure 2. Incidence of various cancer types in Eastern Europe [6]

In Eastern European countries, persistent delays and inadequancies in cancer management strategies still exist, resulting in pronounced differences among Western and Eastern European countries in cancer incidence and mortality rates (Figure 2.) [11,12]. With the increase in life expectancy, the incidence of chronic diseases and thus, the mortality rate associated with them has increased as two thirds of cancers are diagnosed in patients over 60 years of age [8]. The phenomenon of the ageing population is also present in Hungary: the population of the country has been decreasing by $0.2-0.3 \%$ every year since 1982 , while the mortality associated with malignancies increased by $50 \%$, compared to the mortality rates of 1960 's, due to the increase in average life expectancy (ALE) and lifestyle changes [12-14]. In the period between 2009 and 2013, there was on average 85,000 new cases and 33,000 cancerrelated deaths in Hungary; mortality was most frequently due to lung (31\%), colorectal (16\%), prostate and oral cancer (7\%) in males, while in females, lung (21\%), colorectal (16\%), breast $(15 \%)$ and cervical $(6 \%)$ cancers were predominant $[15,16]$. International variations and sex differences in rates of lung cancer reflect historic differences in the pattern of smoking uptake and cessation, and the degree of the tobacco epidemic [6,12,17]. In Hungary, lung cancer rates are also decreasing in men, but continuing to increase in women, due to the delayed peak in the tobacco epidemic. Among the EU member states, the incidence of lung and colon cancers and the mortality associated with these tumors is highest in Hungary (Figure 3.) $[15,16]$. 


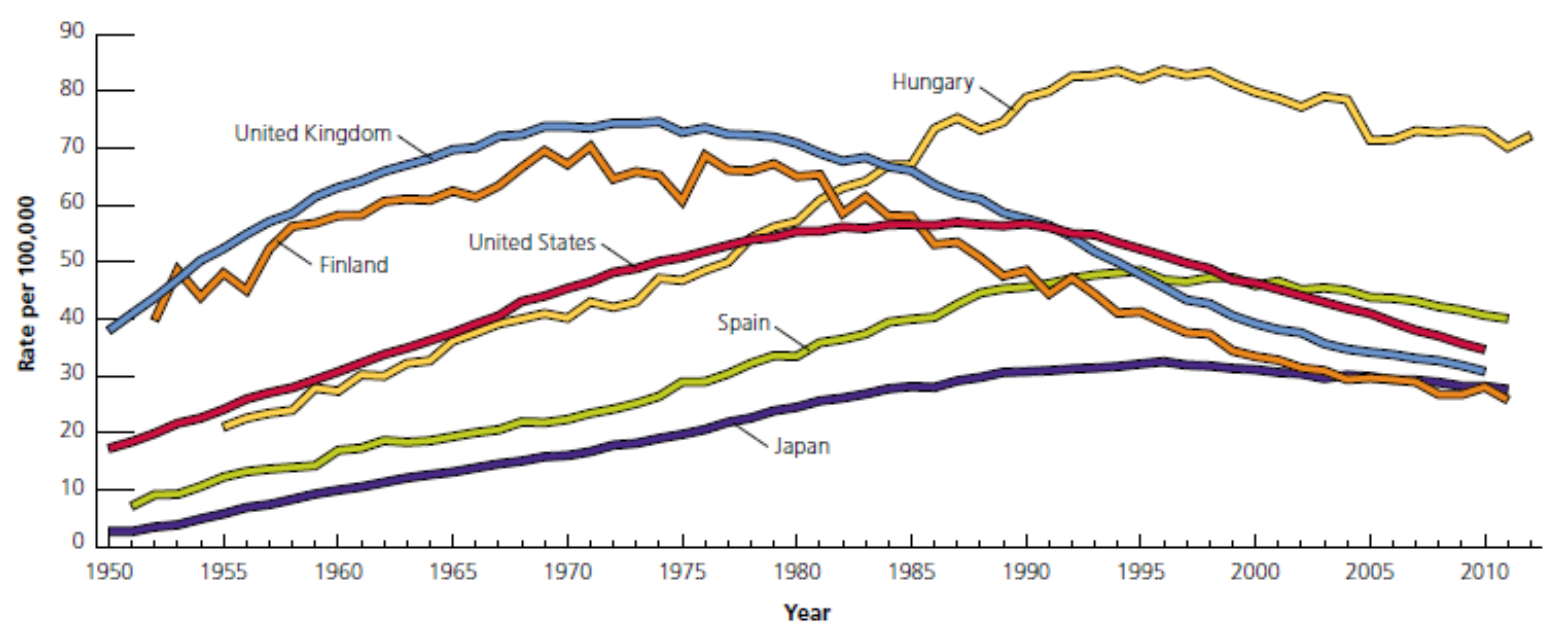

Figure 3. Incidence rates of lung cancer in developed countries between 1950-2010 [2]

\section{B. Basic concepts of malignant diseases, treatment options}

Cancer refers to a broad group of diseases characterized by the conversion of healthy cells into malignant cells that are able to divide and grow uncontrollably, becoming a danger to the integrity of the rest of the organism $[5,6,8,18]$. The biological characteristics of malignant cells that differentiate them from healthy cells in the body were proposed by Hanahan and Weinberg [19], which are the following: a. quick division without the need to receive external stimuli in form of growth signals, b. inability to trigger apoptotic processes due to repression of these pathways, despite having considerably altered genetic material, c. lack of functioning cell cycle checkpoints and inability to respond to growth inhibition signals (i.e., senescence), d. release of substances that stimulate formation of new blood vessels (angiogenesis) to ensure the supply of nutrients, allowing them to divide quickly, e. invasion of adjacent tissues and migration within the body (through the bloodstream or lymphatic system) from the original malignancy; this process of secondary tumor formation is called metastasis and it is a characteristic of invasive carcinomas, f. they possess unlimited replicative potential, unlike normal cells, which can only divide a finite number of times (Figure 4.). Cancer cells exhibit a typical histological appearance when observed microscopically, while the shape of the cells may be heterogeneous within the same tumor [20-22].

As for the causative agents of malignant disorders, an etiological approach is generally accepted that genetic predisposition (e.g., hereditary mutations in the BRCA gene cause an increased risk for developing breast and ovarian cancer) [23], lifestyle choices (tobacco and alcohol consumption, sedentary lifestyle, diet and nutrition) [2,6], environmental factors (pollution, occupational exposure, contamination with carcinogens, ultraviolet and ionizing radiation) [6,24], chronic infections (Helicobacter pylori, HPV, HBV, HCV, EBV, HIV, HTLV and Schistosoma haematobium) [25-29] and other factors, such as immunosuppression and various medicinal drugs (e.g., oral contraceptives, cyclosporine A) all play important roles in the development of neoplasms [6]. The transformation of normal cells to tumor cells is a slow and gradual process, involving three distinct stages: initiation, promotion and progression [19]. 
Years or decades may pass from the underlying molecular event (e.g., DNA damage, induction of mutations in critical target genes, activation of proto-oncogenes, inactivation of tumor suppressor genes) to the development of symptoms and clinical disease [30-32]. Malignant transformation occurs if cells suffer a series of successive mutations that affect mechanisms that regulate cell division or programmed cell death [33].

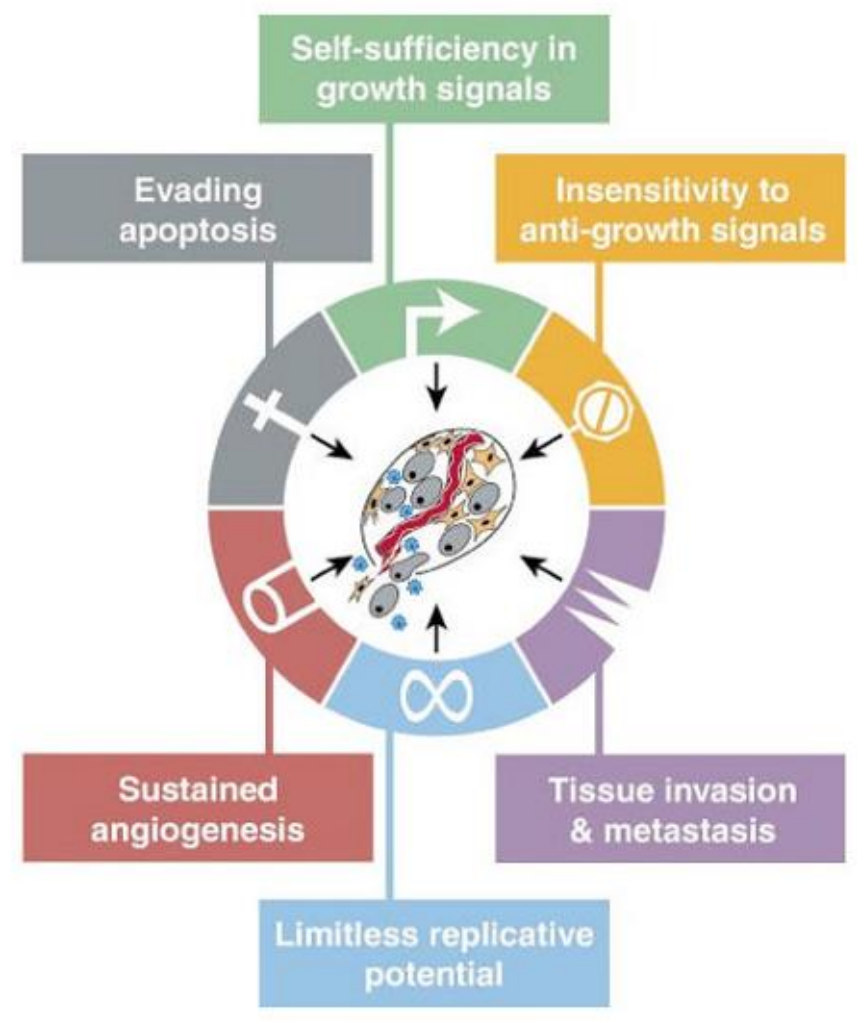

Figure 4. The biological characteristics of malignant cells [19]

The main objective of cancer treatment is the elimination of all tumor cells present in the patient's body. However, this is not always possible, as in the case of hematological malignancies (e.g., leukemia, lymphoma) or metastatic tumors, therefore, the purpose of treatment is to reduce the number of malignant cells, relieve symptoms, prolong the survival of the patient and improve the quality of life (QoL) [19,34]. The selective killing of cancer cells is a challenging task, due to the similarities with normal tissue. The three most commonly utilized strategies for the treatment of cancer are: surgery, radiotherapy and chemotherapy, which can either be used alone or in combination. Surgical excision of tumors is the oldest existing therapeutic alternative, which consists of removing the primary malignancy with the adjacent regions of tissue. It can be used for curative, preventive (removal of benign tumors or organs preemptively) and diagnostic (performing biopsies) purposes. Radiation therapy is characterized by using high-energy particles to generate mutations in critical genes in cancer cells, making them unviable. This treatment modality takes advantage of the higher sensitivity of malignant cells to radiation, due to their high rate of division. It is used both as curative therapy against tumors sensitive to radiation, and to reduce tumor mass before surgery [35]. 
When it comes to the treatment of cancer, chemotherapy is the most frequently used method, both for hematological malignancies and solid tumors. Chemotherapy uses cytotoxic drugs with various mechanisms of action to destroy cancer cells. Depending on the aim of administering the drugs, chemotherapy may be curative (aiming for remission), adjuvant (complementing the efficacy of another therapeutic modality), neoadjuvant (administration of therapeutic agents before a main treatment) or palliative (appropriate for relieving symptoms and improving QoL) [34]. Some of these drugs originated from molecules found in nature (e.g., vincristine and paclitaxel), while others are products of synthetic chemistry (e.g., temozolomide). They can exert their antitumor activities through inhibition of nucleic acid synthesis (e.g., methotrexate, 5-fluorouracil), alkylating DNA (e.g., cyclophosphamide, cisplatin), modulation of the microtubule system (e.g., vincristine, paclitaxel), inhibition of the topoisomerase enzymes (e.g., doxorubicin, irinotecan) or through being hormone receptor agonists/antagonists (e.g., buserelin, tamoxifen).

However, most of the anticancer drugs do not selectively target tumor cells, but also healthy cells that divide frequently, such as the bone marrow and the epithelium. Therefore, the administration of these agents is associated with serious side effects, such as nausea and vomiting, phlebitis, alopecia, anemia, thrombocytopenia and leukopenia (or presenting as pancytopenia), kidney failure and lesions on the liver and in the lungs. Moreover, a number of antitumor agents (e.g., cyclosporine, thiotepa, tamoxifen) are also accountable for the formation of secondary tumors [36-39]. Moreover, most of the anticancer agents currently used in clinical practice have low bioavailability, therefore they cannot reach their cellular targets in high concentrations $[40,41]$. From a clinical perspective, the efficacy of cancer chemotherapy can be classified as complete remission (CR; the entire tumor mass is eliminated), partial remission (PR; the size of the tumor is decreased by more than $50 \%)$, stable $(<50 \%$ change in tumor size) or progression (more than $25 \%$ increase in size) [42].

Recently, new types of chemotherapeutic agents have been introduced into the clinical practice: a. monoclonal antibodies (such as trastuzumab) binding to specific extracellular antigens on the surface of cancer cells $[43,44]$, b. small-molecule tyrosine-kinase inhibitors (TKI, such as imatinib), targeting phosphorylation cascades and signal transduction intracellularly $[45,46]$, c. genetically engineered chimeric antigen receptor (CAR) T-cells, designed to attack various blood cancers and solid tumors [47-50]. These agents represent a novel approach to cancer treatment, but due to their similarly severe adverse reactions, limited accessibility, high price and narrow therapeutic indications, they are not likely to soon replace classic cytotoxic drugs [51,52]. 


\section{Mechanisms of multidrug resistance (MDR) in cancer cells}

Due to its significant drawbacks, chemotherapy cannot be considered as an all-round solution for the treatment of malignant diseases [34]. Another factor to consider, which complicates treatment further, is the emergence of drug resistance, which affects around onethird of cancer patients overall [53,54]. Drug resistance in cancer is a well-known event in the clinical practice, which was first described in vivo by Dano et al. in respect to Ehrlich-Lettre ascites carcinoma cells showing cross-resistance to vinca alkaloids [55]. The phenomenon whereby tumors show resistance to chemotherapeutic agents of different structure and mechanism of action is termed multidrug resistance (MDR) [56]. Drug resistance in tumors can be of intrinsic and acquired origin, both are associated with sub-optimal clinical outcomes [57]. Intrinsic resistance can be detected right as the tumors fail to respond to first-line agents, while acquired resistance is often observed when the malignancy responds favorably to initial treatment, but on recurrence, the same therapeutic regimen has little or no effect [58]. MDR may be mediated by the following mechanisms: a. drug compartmentalization, b. changes to the structure and permeability of cell membrane lipids, c. changes in metabolic pathways, d. overproduction of the target molecule(s), e. induction of DNA repair, f. alterations in target molecules, g. drug inactivation, h. epigenetic effects, i. inhibition of programmed cell death (apoptosis), $\mathbf{j}$. overexpression of efflux pump proteins. It is not uncommon for cancer cells to be resistant to cytotoxic drugs due to multiple mechanisms present at once (Figure 5.) $[59,60]$.

In recent literature, however, the MDR of cancer cells is treated as a broader concept, defining four main factors associated with therapeutic failure: ATP-binding cassette $(A B C)$ and other energy-dependent efflux pump mechanisms, defective apoptotic pathways, tumor cell heterogeneity and presence or self-renewing tumor "stem cells" and the tumor microenvironment. Other sources define resistance mechanisms as tumor cell-dependent or microenvironment-dependent [61]. Research related to MDR and experimental model systems commonly approach these resistance mechanisms one by one [62]. However, more and more studies suggest that these mechanisms need to be considered in in vivo experiments as the phenotype of MDR in the clinical setting is resulting from the complex interplay and synergy of these molecular mechanisms [61]. For the purposes of this thesis, the importance of deficiencies in apoptosis induction and efflux pump-mediated MDR of cancer cells will be discussed in detail.

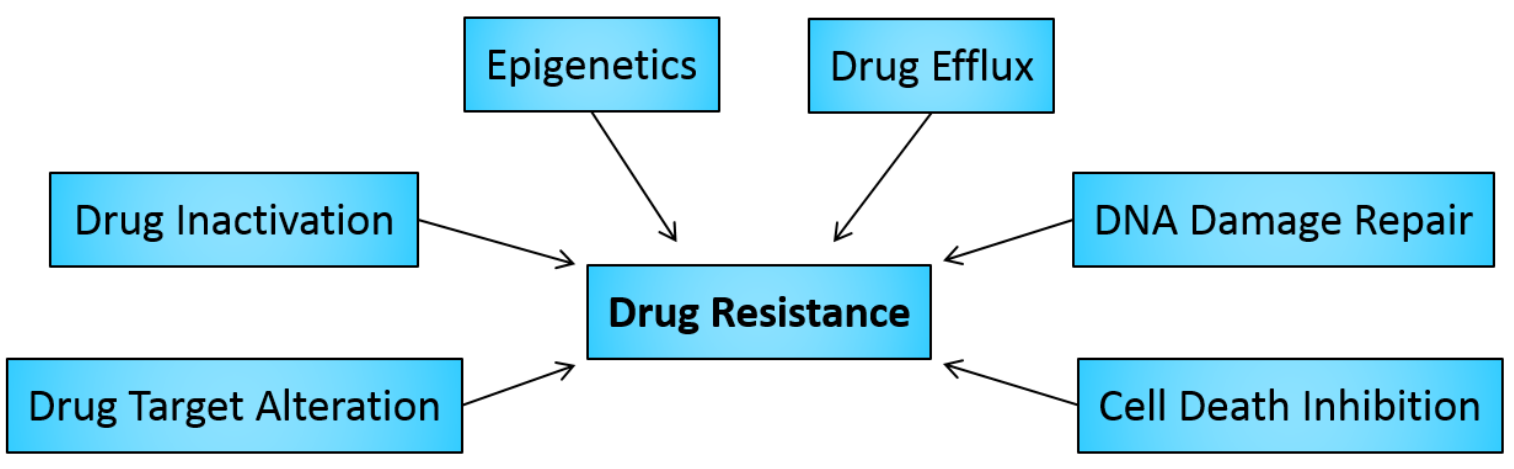

Figure 5. Mechanisms of multidrug resistance (MDR) in cancer cells [57] 


\section{a. Efflux pump mediated drug resistance, ABC transporters}

One of the best characterized mechanisms of MDR is the ability of cancer cells to remove the anticancer agents from inside their cytoplasm (thus, reducing their therapeutic efficacy), due to the overexpression of energy-dependent efflux pumps [56]. The ATP-binding cassette $(\mathrm{ABC})$ transporter superfamily is an extremely important and prevalent group of transport proteins in the human body $[63,64]$. ABC transporters bind and hydrolyze ATP to provide the energy needed to transport their substrates across the cell membranes [65]. Two of the most important structural elements of these pumps are the nucleotide binding regions (NBDs, responsible for binding ATP) and their transmembrane domains (TMs, anchoring the proteins into the cytoplasm and providing the channel for extruded compounds) [66]. Under physiological conditions, these transport proteins can be found in almost all tissues of the body, and they are essential for the healthy functioning of barrier systems (blood-brain, blood-testes, blood-thymus), the placenta, bronchi, sweat glands, intestinal absorption and the proximal tubules of the kidney $[67,68]$. These transporters are vital for the defense of healthy cells against toxic compounds, and they also play a role in the elimination of harmful endogenous metabolites and xenobiotics (e.g., various chemical agents, medicines) [65,67]. To date, 49 distinct types of $A B C$ genes have been described, which are divided into 7 subfamilies (A-G) based on sequence homology and number of transmembrane domains (which may be 6, 12 or 17 TMs) [65,69].

The first characterized ABC transporter was the 170kDa ABCB1 (MDR1/P-glycoprotein/Pgp170), which has since become the most studied member of the superfamily, because it was recognized early on that the overexpression of this protein is often associated with the development of MDR phenotype in cancer and disadvantageous clinical outcome [68-70]. This transporter consists of twelve TMs and two NBDs (Figure 6.). Other transport proteins are also implicated with MDR in anticancer therapy, the most clinically relevant transporters include ABCC1/MRP1, ABCB2/MRP2 and ABCG2/BRCP [58,64,71].

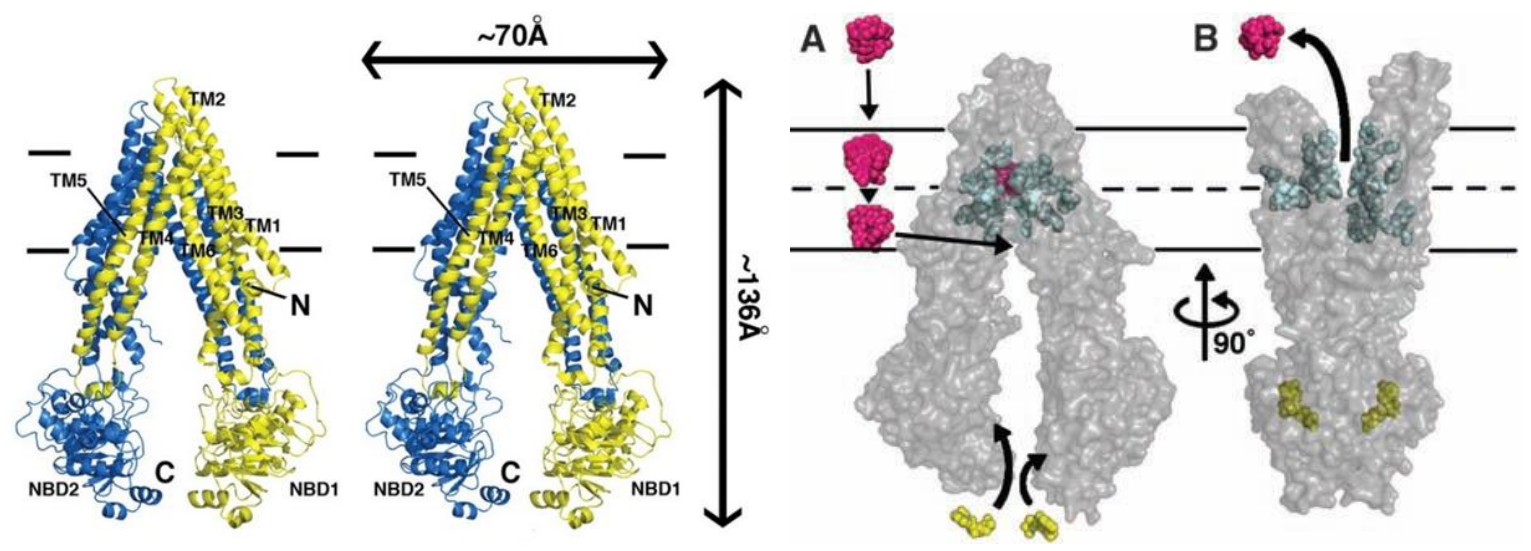

Figure 6. Three-dimensional structure of the ABCB1 protein [66] 
The operation of the ABCB1 efflux protein is characterized by a conformational change; after binding the compound has to be expelled and ATP has been hydrolyzed, the substrate is then removed. Due to the flexible and non-specific substrate binding site of this transporter, it can expel a wide variety of chemotherapeutic agents (e.g., anthracyclines, Vinca alkaloids, taxanes, steroid derivatives, colchicine), peptides and other amphiphilic compounds that would be detrimental for the survival of the cells $[65,66,72]$. Therefore, it is not difficult to concur that overexpression of this transporter is associated with the MDR phenotype of tumor cells [57]. An emerging research approach and therapeutic strategy is the use of efflux pump inhibitors (EPIs) as adjuvant compounds (so-called 'chemosensitizers') to improve the efficacy of antitumor therapy, by co-administering them with chemotherapeutic agents [40,65,73-75]. Considerable number of compounds have been described capable of inhibiting the function of the ABCB1 efflux pump, therefore reversing the MDR phenotype associated with these cancer cells [76,77]. Efflux pump modulators of the ABCB1 pump can be assigned to three different generations of compounds:

i. first generation $\mathrm{ABCB} 1$ inhibitors are medicinal drugs, whose primary pharmacological effects are not associated with the inhibition of efflux pump function. The activity of compounds, such as verapamil $\left(\mathrm{Ca}^{2+}\right.$-channel blocker for the treatment of arrhythmias), cyclosporin A (immunosuppressive), quinidine (antimalaria drug) and tamoxifen (selective estrogen receptor modulator) was observed subsequently. These compounds are in fact, substrates of $\mathrm{ABCB} 1$, therefore they competitively inhibit the expelling of other substances. Taking this into consideration, these drugs would need to be administered in high doses to produce adequate concentration in vivo for adequate clinical activity. Because most of these compounds cause serious toxic side effects, their potential use as MDR reversing agents in clinical practice was discarded [76,78-80] (Figure 7.).

ii. second generation $\mathrm{ABCB} 1$ inhibitors, e.g., dexverapamil, dexniguldipine, valspodar (PSC-833) or biricodar (VX-710) are chemically modified derivatives or enantiomers of firstgeneration agents. As they have weak or no pharmacological activities associated with their parent compounds, they do not have the dose-limiting side effects that plagued the drug molecules, however, their potency to inhibit the transporter protein was retained. The disadvantage of these compounds is that they are substrates of the cytochrome P450 enzymes (particularly CYP3A4), resulting in peculiar pharmacokinetic patterns, making the dose adjustments during chemotherapy difficult. In addition, these molecules also inhibited other efflux pumps in the body that are required for physiological integrity, thus causing some offtarget responses (e.g., neurological toxicity) [76,78,81,82] (Figure 7.).

iii. third generation inhibitors of $\mathrm{ABCB} 1$ are products of high-throughput screening and combinatorial chemistry, targeted specifically for inhibition of pump function. They do not possess the limitations of previous generation compounds; they have no other pharmacological activity, they do not influence the pharmacokinetic parameters of antitumor drugs and they specifically inhibit ABCB1, without being a substrate of this pump or affecting other ABCtransporters. Another advantage of compounds, such as tariquidar (XR9576; an anthranilamide derivative), zosuquidar (LY335979; cyclopropyl-dibenzosuberane derivative) and laniquidar (R101933; a chemically modified derivative of verapamil) is that they exhibit efflux pump modulatory activity in very low concentrations (in the nanomolar range), which is advantageous 
for in vivo dosage [56,76,78] (Figure 7.). The pharmacokinetic properties of these compounds were studied in several Phase I clinical trials and they were well tolerated by the participants, no dose-limiting toxicity (DLT) was observed in a wide therapeutic dose range (50-400 $\mathrm{mg} /$ day) [83-86]. However, the co-administration of these compounds with standard-of-care chemotherapy in various Phase II-III clinical trials did not significantly alter clinical outcomes or patient survival, as a result, none of these compounds have been marketed or used in clinical therapy thus far $[72,78,84,87,88]$.

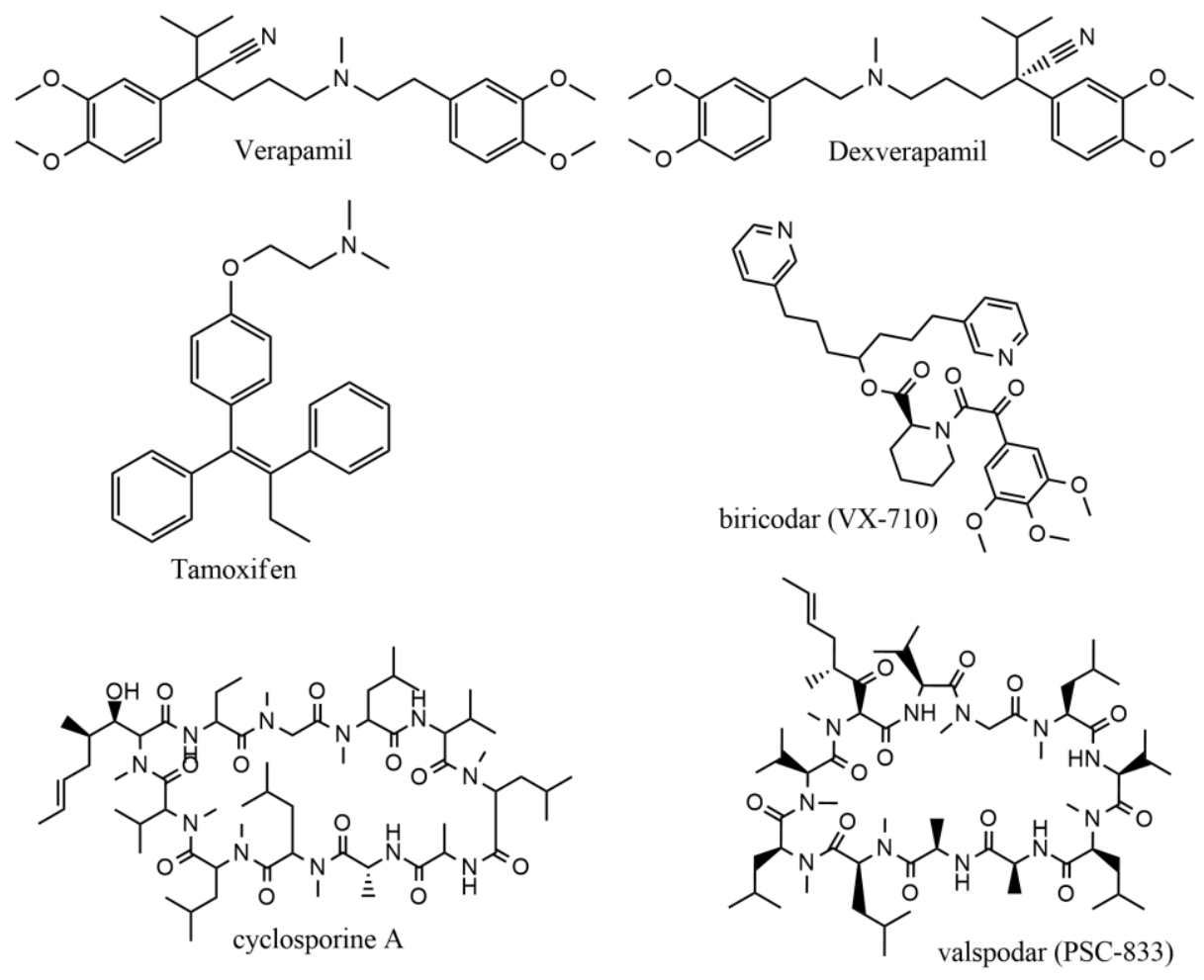

First generation modulators of the ABCB1 transporter

Second generation modulators of the $\mathrm{ABCB} 1$ transporter

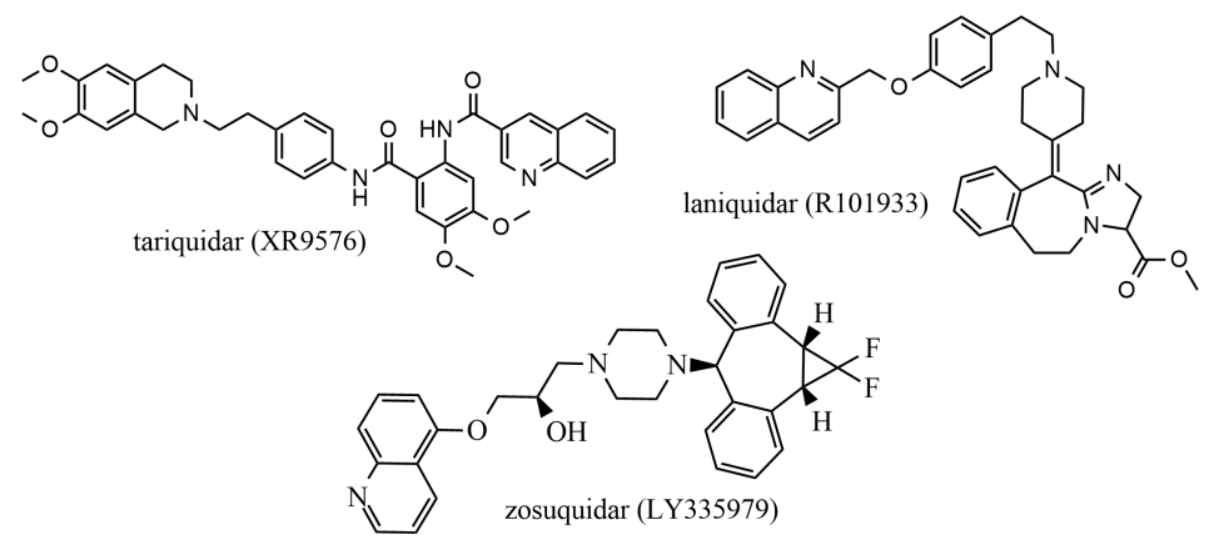

Third generation modulators of the $\mathrm{ABCB} 1$ transporter

Figure 7. Chemical formula of first to third generation $\mathrm{ABCB} 1$ inhibitors (adapted from $[79,80]$ ) 


\section{b. Programmed cell death (apoptosis)}

Cell proliferation is a continuous process in the human body, therefore various mechanisms are necessary for keeping the number of cells constant in organs and for the preservation of physiological tissue homeostasis $[89,90]$. The division of cells is under similar supervision, as the cell cycle is controlled at three distinct checkpoints: at the G1/S phase transition, at the end of the $\mathrm{G} 2$ phase and in the metaphase of the $\mathrm{M}$ phase. Under normal circumstances, cell division can only occur, if there were no errors detected in the processes of respective phases [18,91]. Otherwise (e.g., DDR; DNA damage response is initiated), cyclin-dependent kinase-inhibitors (Cdk-i) are activated [92,93]. If the error in the genetic material of the cell cannot be repaired, the production of apoptotic proteins is consequently induced, leading to cell death [94].

One of the most important forms of cell death induced by antitumor chemotherapy is apoptosis and MDR is a scenario where the apoptotic processes are defective, resulting in therapy refractory malignancy; this may occur due to loss (e.g., p53) or overexpression (e.g., $b c l-2)$ of genes $[57,94,95]$. The molecular mechanism of apoptosis is a conserved signaling pathway, which takes place the same way, irrespective of the stimuli and the type of cell affected. Apoptosis may be triggered through three distinct pathways: the intrinsic (or mitochondria-dependent), the extrinsic (or death receptor-mediated) and the intrinsic endoplasmic reticulum (ER) pathway [96,97]. Caspases are the proteins that initiate and execute apoptotic processes. Seven different caspases are involved in apoptosis: caspases 2, 8, 9, and 10 are initiators; while caspases 3, 6, and 7 are executioner caspases [98]. Caspases are synthesized as proenzymes that need to be activated through the withdrawal of an inhibitory domain by proteolysis. The difference between the two subgroups of caspases resides in their activation: initiators are cleaved by autolysis induced by a conformational change produced by binding to certain proteins (FADD in the extrinsic pathway and Apaf-1-Cytochrome c complex in the intrinsic pathway), while the executioner caspases are activated by proteolysis mediated by the initiator caspases [96]. Once caspase 3 is activated the processes are common to both pathways. The apoptotic process is regulated by the activity of caspases, the basis of their selectivity is that they cleave their target proteins at specific aspartic acid residues [99].

The death receptor-mediated pathway is activated by external signals; death receptors are transmembrane glycoproteins that are classified into the tumor necrosis factor receptor (TNF-R) superfamily, while death ligands are also transmembrane-like proteins [94]. In consequence of the receptor-ligand binding, the conformation of death receptors changes, and the binding of various molecules results in the formation of a signal complex, which later activates caspase 8 (initiating apoptosis through activation of caspase 3 ), in addition to induction of other processes [97]. The mitochondrial pathway of programmed cell death is initiated by internal signals, such as viral infection, DNA damage, elevated levels of reactive oxygen species (ROS) or presence of oncogenes. Because of these signals, the permeability of the mitochondrial membrane is increased, and pro-apoptotic compounds flow out to the cytoplasm. The intrinsic ER pathway is lesser known, and it is thought to be dependent on caspase 12 and an adaptor protein known as TNF receptor associated factor 2 (TRAF2) [97]. 
After the proteolytic cascade of apoptosis has been induced, changes occur in the membrane phospholipids of apoptotic cells, causing phosphatidyl serine (PS) to be displaced to the outer surface of the cell membrane (i.e., externalization). During this process, protrusions appear in the cytoplasm as the size of the cell decreases and gradually separates from its neighboring cells in tissue. In the end, the nucleus shrinks and becomes fragmented and chromatin is condensed $[96,100]$.

In contrast, necrotic processes are different from apoptosis, because one or several cells break uncontrollably, releasing their contents (together with mediators of inflammatory processes) to the extracellular space, with no regard for surrounding, healthy cells $[100,101]$. This is usually occurring because a cell was unable to withstand internal (overproduction of free radicals) or external (toxic agents, burns) damage. In addition, necrosis is a passive process, while apoptosis is associated with active participation of the affected cell [101-103].

\section{Selenocompounds and cancer}

Selenium ( $\mathrm{Se}$ ) is an element belonging to the VI.A group of the periodic table (termed 'chalcogens'), which was discovered by Swedish chemists Jöns Jakob Berzelius and Johann Gottlieb Gahn in 1817 [104]. Before the 1950's, Se was regarded as a potentially toxic agent (causing selenosis, characterized by hair loss, CNS disorders, brittle nails, skin rashes and garlic breath, if more than $850 \mu \mathrm{g}$ /day is ingested), however, nowadays selenium is known as an important trace element [105]. This is further underlined by the various diseases associated with Se deficiency (Keshan's disease: a cardiomyopathy occurring in childhood, caused by pathogens, such as coxsackievirus or streptococci, typical of Chinese regions with low Se concentrations in the soil [106]; Kashin-Beck disease: myxedematous cretinism due to a coexisting deficiency of iodine and selenium, which causes the iodothyronine deiodinase enzyme to function at a low capacity [107]) and other illnesses, where association was found with serum levels of Se and disease progression (immune function [108], mental disorders [109], hypercholesterolemia [110], type-2 diabetes [111], asthma [112] and arthritis among others [113]). For this reason, the US Food and Drug Administration (FDA) recommends a daily intake of $55-70 \mu \mathrm{g} /$ day in a healthy diet $[113,114]$.

Se can be present in various chemical forms in the human body, like Se-containing amino acids (selenomethionine, selenomethylselenocysteine, selenocysteine) and selenoproteins [115,116], methylselenol, selenodiglutathione and inorganic Se-compounds $\left(\mathrm{H}_{2} \mathrm{Se}, \mathrm{Na}_{2} \mathrm{SeO}_{4}\right.$, selenophosphate) [117], thus being an integral part of our biochemical homeostasis, while excretion of Se-compounds usually occurs through the lungs and urine [114,118]. Many selenoderivatives, both organic and inorganic [119], have been studied as cancer chemopreventive agents and/or as cytotoxic compounds [120] for tumor cells and these results are supported by epidemiological trials (see Nutritional Prevention of Cancer [NPC] [121], Selenium and Vitamin E Cancer Prevention Trial [SELECT] [122,123] and the work of Li et al. [124,125] in China). The rationale behind the notion of Se compounds as cancer therapeutic agents is associated with the common phenotype of all malignant cells [126]. Under physiological conditions, healthy cells are characterized by a low and constant level of ROS and an adequate supply of reducing agents [127]. 
In contrast, malignant cells have increased levels of ROS and a maximum threshold for antioxidant capacity, due to the accelerated metabolism of these cells, contributing to successive cell division and proliferation [128,129]. Recent literature suggests that cancer cells are more vulnerable to exogenous oxidative stress (i.e., their endogenous levels of ROS are closer to the critical threshold at which apoptotic processes are induced) than healthy, non-tumoral cells [130,131]. Another possible strategy is to inhibit the antioxidant mechanisms of neoplastic cells, exposing them to highly damaging species (Figure 8.) $[111,129,132]$. The latest research point to the fact that modulation of oxidative stress as an attractive target for the rational design of novel anticancer agents with selective activity [128,133-136]. The activity of organic compounds containing chalcogen elements (particularly Se) gained reasonable attention in the field of modulation of ROS in malignant cells, both as chemopreventive (antioxidant) agents and cytotoxic drugs [127-129,135-139]. An increasing number of biological studies are also involved in the production of reactive selenium species (RSeS) after treatment of cells with organic selenium compounds [140].
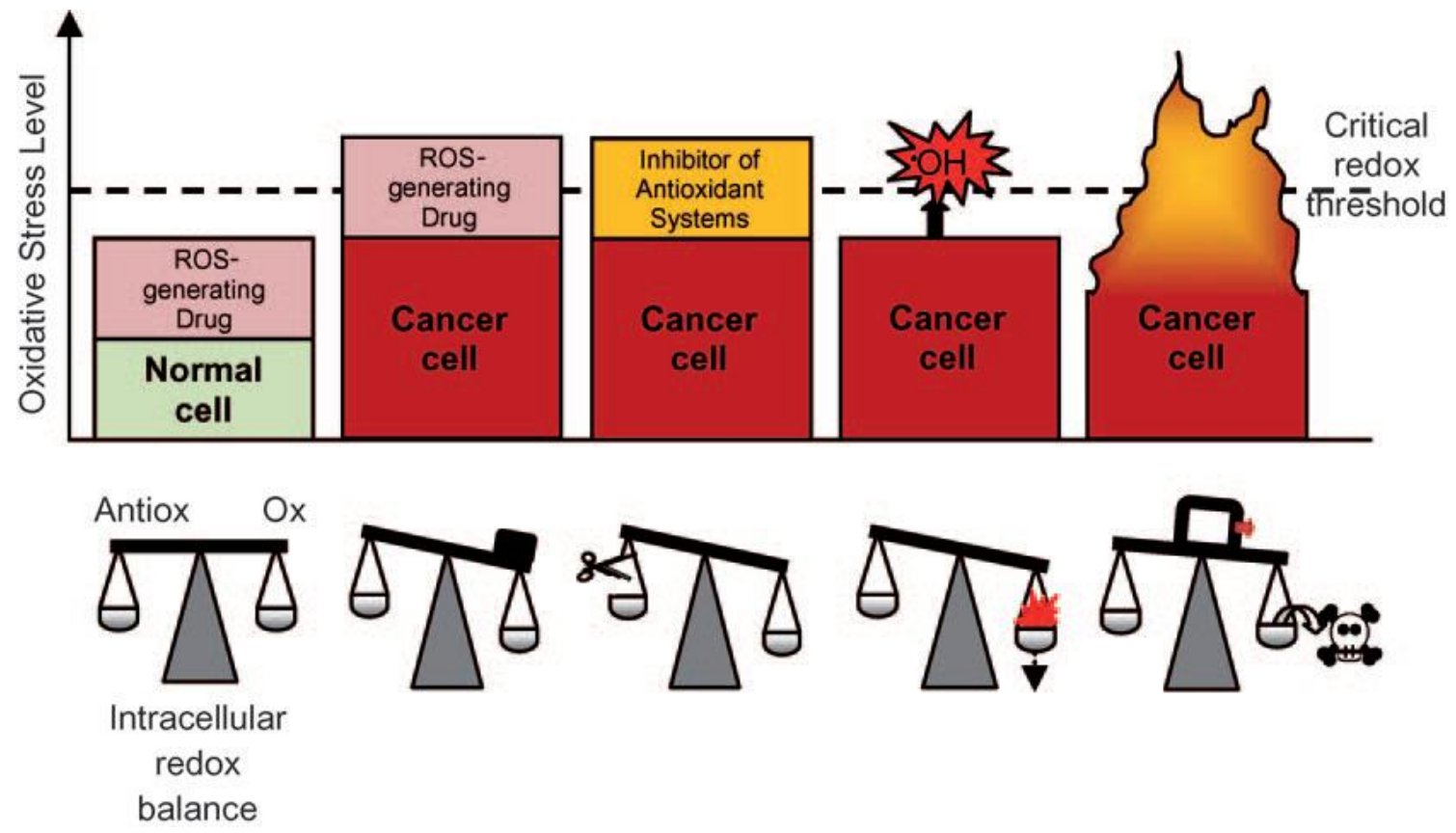

Figure 8. Modulation of intracellular redox state as an attractive target for therapeutic purposes [129]

Initially, experimental studies tested inorganic selenium compounds (selenites, selenates, Se-dioxide) for their cytotoxicity and their potential for enhancing the efficacy of chemotherapy as adjuvants [117]. However, successive investigations discovered that organoselenium derivatives presented with superior biological activities and with less toxicity [139]. These compounds were tested in a wide range of in vitro cancer cells model systems and in animal experiments, exhibiting potent anticancer and ROS-modulating properties, both as singular agents and in combination chemotherapy with clinically relevant anticancer drugs [141]. The most relevant organoselenium compounds in experimental oncopharmacology include methlyseleninic acid [142], selenoamino acids [115], organic selenides and diselenides [143], selenocyanates, Se-containing heterocycles, sugar esters, steroids and nucleoside analogues $[111,144]$. 
Nanoparticles containing Se (SeNPs) are also attractive therapeutic modalities, due to their excellent bioavailability and low toxicity [145]. In addition, the surface of these nanocarriers may be augmented (surface-decorated SeNPs) with conjugation of various ligands (e.g., sialic acid, folate, transferrin) to target proteins that are overexpressed on cancer cells [146]. Keeping in mind that these nanoparticles are colloidal systems, there is additional opportunity for controlled release of biologically active agents and to make in vivo pharmacokinetic properties more advantageous [147].

The effect of organoselenium compounds on mammalian cells is influenced by many factors. The anticancer activity of Se-compounds is often described as a "double-edged sword": on one hand, a large number of studies concluded that Se-supplementation is associated with cancer risk reduction (antioxidant), on the other hand, a plethora of in vitro studies demonstrated that malignant cells are more sensitive to Se compared to healthy cells (pro-oxidant) [138]. Apart from the ability of the compounds to modulate the intracellular redox state of the cells, they may act through inducing double stranded DNA breaks or facilitating DNA repair, controlling cell cycle progression, influencing the expression of various signal molecules in cellular processes (Figure 9.) $[138,139,141]$. The compounds may also influence disease pathogenesis indirectly, through modulating immune functions (e.g., levels of various cytokines) [148], angiogenesis [149] and inhibition of metastasis formation [150]. Se-compounds in various chemical forms (inorganic vs. organic) and with dissimilar functional groups also presented with different biological activity [137,141]. The concentration of the tested Se-compound also has a significant role, their efficacy usually takes up a U-shaped curve depending on the dose [114]. Another important variable is the redox homeostasis and metabolic activity of the model systems (cell lines, test animals) used [136]. In fact, some studies suggest that two intracellular processes are simultaneously initiated after the treatment of cells with organoselenium compounds: firstly, due to decreased thiol levels, the amount of ROS increases in the cells, which in turn will cause the cleavage of PARP (an important mediator of programmed cell death and DNA repair), inducing pro-apoptotic processes [151,152]. On the other hand, antioxidant systems are also induced simultaneously, and if intracellular thiol levels are normalized and the oxidative damage is counteracted, then pro-survival processes are initiated [127] (Figure 8.). Therefore, the conditions of the cells before the Se-compounds exert their effects also play a role in what direction the redox status of the cells will shift. It should also be remembered that glutathione peroxidase (GPx) plays a key role in the redox balance of our body, and the deficiency in this enzyme (which is Se-dependent) increases the incidence of tumor formation $[127,141]$. 


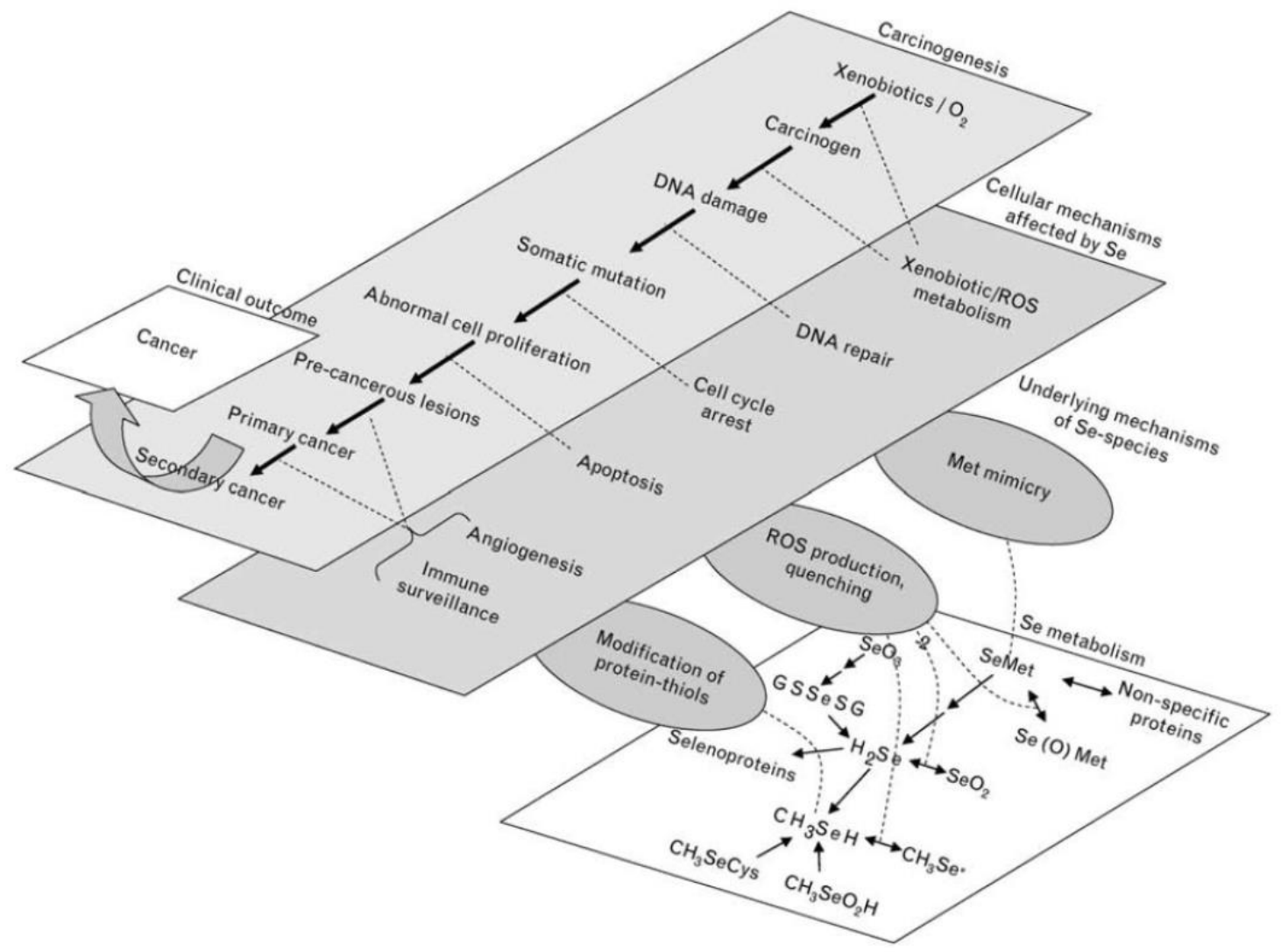

Figure 9. Possible mechanisms of anticancer activity for selenocompounds [153]

Based on the promising data available in the literature related to novel Se-based anticancer agents, a new structural variety of organoselenium compounds (cyclic selenoanhydride and selenoesters) were synthesized by Domínguez-Álvarez et al. [154]. The study group of Domínguez-Álvarez evaluated the structure and stability of the new compounds, as well as their redox modulating properties using chemical methods and their nematicidal activity [154-156]. The subject of this thesis the characterization of the abovementioned organoselenium compounds as novel antitumor agents and potential compounds for reversing multidrug resistance in cancer. In addition, their potential for future in vivo use is also assessed using in silico methods. 


\section{AIMS OF THE STUDY}

The aim of our study was to evaluate the activity of novel organoselenium compounds synthesized by Domínguez-Álvarez et al. [154] to find effective and selective anticancer derivatives using various cell lines (cell lines of murine and human origin, tumoral and noncancerous cell lines) as in vitro model systems. In addition to their cytotoxic activity, their potency as multidrug resistance reversing compounds was studied against two resistance mechanisms, namely inhibition of ABCB1-mediated efflux and induction of apoptosis in tumor model systems. Furthermore, their attributes as potential lead compounds for further derivatization and their potential for future in vivo use were also investigated.

\section{The specific goals of the study were the following:}

1. Determination of the cytotoxic activity and selectivity of the compounds (a cyclic selenoanhydride, ten selenoesters and four inorganic chalcogen cyanates) on L5178Y parental (PAR) and $A B C B 1$-transfected resistant (MDR) mouse T-cell lymphoma cell lines, Colo 205 (doxorubicin-sensitive) and resistant Colo 320 (ABCB1-overexpressing) human colonic adenocarcinoma cell lines, A549 human lung adenocarcinoma cells, NIH/3T3 mouse embryonic fibroblast, and MRC-5 human embryonic lung fibroblast cell lines by MTT method.

2. Evaluation of the efflux pump modulatory activity of the compounds (a cyclic selenoanhydride, ten selenoesters and four inorganic chalcogen cyanates) on L5178Y parental (PAR) and $A B C B 1$-transfected resistant (MDR) mouse T-cell lymphoma cell lines, Colo 205 (doxorubicin-sensitive) and resistant Colo 320 (ABCB1-overexpressing) human colonic adenocarcinoma cell lines using a flow cytometry-based rhodamine 123 retention assay.

3. Characterization of the selenocompounds (a cyclic selenoanhydride, ten selenoesters and four inorganic chalcogen cyanates) as apoptosis inducers using Annexin V-FITC detection system on L5178Y parental (PAR) and ABCB1-transfected MDR mouse T-cell lymphoma cell lines and resistant Colo 320 (ABCB1-overexpressing) human colonic adenocarcinoma cell line.

4. In silico analysis of predicted physico-chemical and in vivo absorption properties of the compounds using OSIRIS Molecular Property Explorer and PreADMET 2.0 software. Correlation-regression analysis to study the relationship between the predicted physicochemical properties of the selenocompounds and their activity as efflux pump inhibitors.

5. Determination of structure-activity relationships (SAR) of the selenocompounds based on experimental results. 


\section{MATERIALS AND METHODS}

\section{A. Compounds}

\section{Organoselenium compounds}

The tested compounds include a cyclic selenoanhydride (1) and selenoesters (2-11) with various functional groups (2-5: methyl group; 6: amide; 7-8: carboxylic ester; 9-11: ketone) (Figure 9. and Table 1.; Appendix 1.). The synthesis of the cyclic selenoanhydride (1) was carried out by the reaction of lithium aluminium hydride with selenium in anhydrous tetrahydrofuran (to generate the selenating agent), followed by the reaction with 2-benzofuran1,3-dione or phthaloyl chloride and a final dehydration step with sulfuric acid (Appendix 2.), with yields up to $94 \%$ [154]. The selenoesters (2-11) were synthesized by the reaction of sodium hydrogen selenide (generated by the reaction of elemental selenium powder and sodium hydrogen selenide) and the aroyl or heteroaroyl chloride, after which the intermediate sodium aroylselenide products were treated with the corresponding $\alpha$-halo derivative (Appendix 3.), based on a protocol devised by Sanmartín et al [156]. The yields of this reaction scheme were around $70 \%$ for all compounds. Additionally, some of the compounds could be synthesized from the corresponding selanylacetic acids by Fischer esterification, with yields varying between 18-63\% [154,156]. The cyclic selenoanhydride (1) could also be obtained by the procedure based on the sodium boronhydride reaction, although with considerably lower yields (around 18\%). The synthesized compounds were pure and chemically stable on air, according to the spectroscopic $\left({ }^{1} \mathrm{H},{ }^{13} \mathrm{C}\right.$ NMR, MS) and elemental analysis carried out for the structure confirmation of the compounds [154]. The stock solutions (in $10 \mathrm{mM}$ concentration) of the compounds were prepared in DMSO.
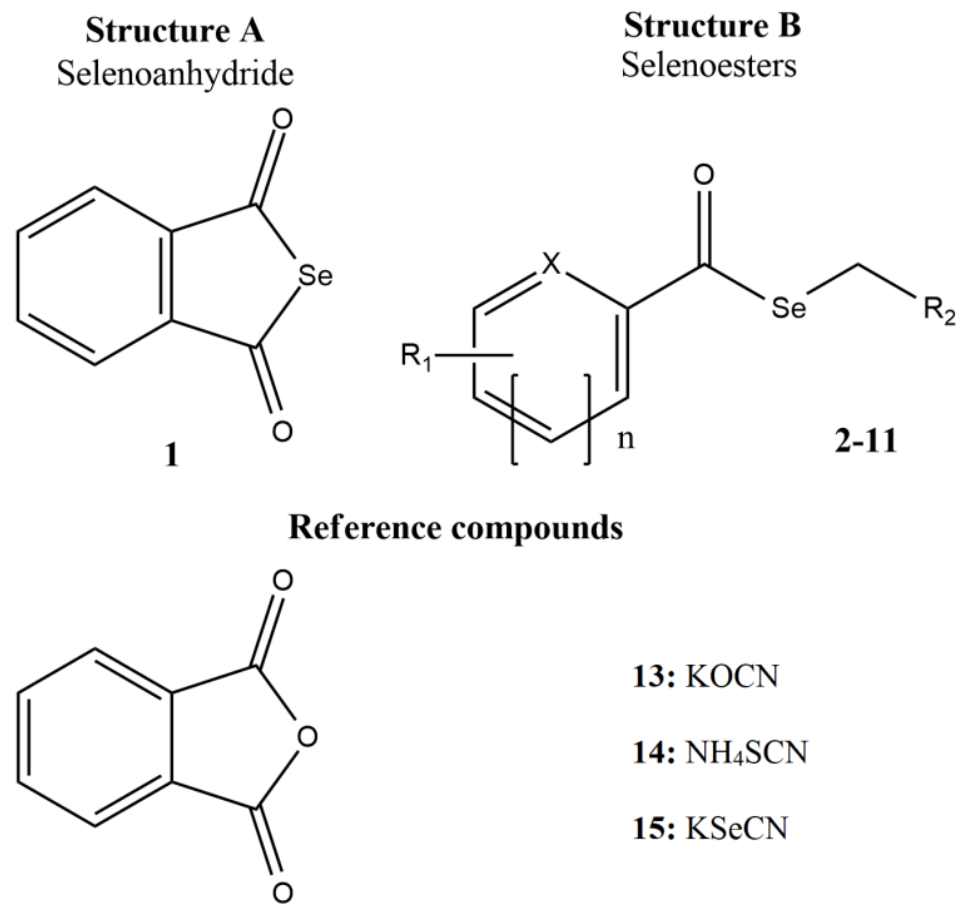

12: Phthalic anhydride

Figure 9. Structure of the tested compounds (1-15) 
Table 1. Substituents of the tested compounds (1-11)

\begin{tabular}{|c|c|c|c|c|c|}
\hline Compound & Structure & $\mathbf{n}$ & $\mathbf{X}$ & $\mathbf{R}_{\mathbf{1}}$ & $\mathbf{R}_{\mathbf{2}}$ \\
\hline 1 & A & - & - & - & - \\
\hline 2 & B & 0 & $\mathrm{~S}$ & $5-\mathrm{COSeCH}_{3}$ & $-\mathrm{H}$ \\
\hline 3 & B & 1 & N & $6-\mathrm{COSeCH}_{3}$ & $-\mathrm{H}$ \\
\hline 4 & B & 1 & $\mathrm{C}$ & $3-\mathrm{COSeCH}_{3}$ & $-\mathrm{H}$ \\
\hline 5 & B & 1 & $\mathrm{C}$ & $4-\mathrm{COSeCH}_{3}$ & $-\mathrm{H}$ \\
\hline 6 & B & 1 & $\mathrm{C}$ & $-\mathrm{H}$ & $-\mathrm{CONH}_{2}$ \\
\hline 7 & B & 1 & $\mathrm{C}$ & $4-\mathrm{Cl}$ & $-\mathrm{COOCH} 3$ \\
\hline 8 & B & 1 & $\mathrm{C}$ & $-\mathrm{H}$ & $-\mathrm{COOPh}_{3}$ \\
\hline 9 & B & 1 & $\mathrm{C}$ & $4-\mathrm{Cl}$ & $-\mathrm{COCH}_{3}$ \\
\hline 10 & B & 1 & $\mathrm{C}$ & $4-\mathrm{Cl}$ & $-\mathrm{COC}\left(\mathrm{CH}_{3}\right)_{3}$ \\
\hline 11 & B & 1 & $\mathrm{C}$ & $3,5-\mathrm{diOCH}$ & $-\mathrm{COC}\left(\mathrm{CH}_{3}\right)_{3}$ \\
\hline
\end{tabular}

Phthalic anhydride (12; the oxygen isoster of compound 1) and three inorganic chalcogen cyanates $\left(13-15 ; 13-K O C N, 14-N_{4} \mathrm{SCN}, 15-\mathrm{KSeCN}\right)$ were included in the study (Sigma) and used as references in the experiments.

\section{Other compounds}

The following compounds were used in the assays as reagents: rhodamine 123 (R123; Sigma, St. Louis, MO, USA; Appendix 4.), 3-(4,5-dimethylthiazol-2-yl)-2,5-diphenyltetrazolium bromide (MTT; Sigma, St Louis, MO, USA), sodium dodecyl sulfate (SDS; Sigma), verapamil (EGIS Hungarian Pharmaceutical Company, Budapest, Hungary), cisplatin (TEVA Pharmaceutical Company, Petah Tikva, Israel) and dimethyl sulfoxide (DMSO; Sigma). All the chemical compounds used in the apoptosis assay, except for the positive control M627 (12H-benzo[ $\alpha]$ phenothiazine; Appendix 5.) were included in the Annexin V-FITC Apoptosis Detection Kit Cat. No. PF 032, purchased from Calbiochem (EMD Biosciences, Inc. La Jolla, CA). The positive control M627 was kindly provided by Prof. Dr. Noboru Motohashi (Meiji Pharmaceutical University, Kiyose, Tokyo, Japan) and dissolved in DMSO. Stock solution of R123 was prepared in PBS and verapamil was dissolved in water. All solutions were prepared on the day of assay.

\section{B. Cell lines}

L5178Y mouse T-cell lymphoma cells (PAR) (ECACC Cat. No. 87111908, obtained from FDA, Silver Spring, MD, USA) were transfected with $\mathrm{pHa}$ MDR1/A retrovirus, as previously described by Cornwell et al [157]. The ABCB1-expressing cell line (MDR) was selected by culturing the infected cells with colchicine. The L5178Y human ABCB1-transfected subline was cultured in McCoy's 5A medium (Sigma-Aldrich, St Louis, MO, USA) supplemented with $10 \%$ heat-inactivated horse serum (Sigma-Aldrich, St Louis, MO, USA), $200 \mathrm{mM} \mathrm{L-}$ glutamine (Sigma-Aldrich, St Louis, MO, USA), nystatin (Sigma-Aldrich, St Louis, MO, USA) and a penicillin-streptomycin mixture (Sigma-Aldrich, St Louis, MO, USA) in concentrations of $100 \mathrm{U} / \mathrm{L}$ and $10 \mathrm{mg} / \mathrm{L}$, respectively. The cell lines were incubated at $37^{\circ} \mathrm{C}$, in a $5 \% \mathrm{CO}_{2}, 95 \%$ air atmosphere. 
Human colonic adenocarcinoma cell lines (Colo 205 doxorubicin-sensitive and Colo 320/MDR-LRP multidrug resistant, overexpressing ABCB1 (MDR1)-LRP), ATCC-CCL220.1 (Colo 320) and CCL-222 (Colo 205) were purchased from LGC Promochem, Teddington, UK. The cells were cultured in RPMI-1640 medium (Sigma-Aldrich, St Louis, MO, USA) supplemented with 10\% heat-inactivated foetal bovine serum (FBS; Sigma-Aldrich, St Louis, MO, USA), 2 mM L-glutamine (Sigma-Aldrich, St Louis, MO, USA), $1 \mathrm{mM}$ Napyruvate, $100 \mathrm{mM}$ HEPES (Sigma-Aldrich, St Louis, MO, USA), nystatin (Sigma-Aldrich, St Louis, MO, USA) and a penicillin-streptomycin mixture (Sigma-Aldrich, St Louis, MO, USA) in concentrations of $100 \mathrm{U} / \mathrm{L}$ and $10 \mathrm{mg} / \mathrm{L}$, respectively. The cell lines were incubated at $37^{\circ} \mathrm{C}$, in a $5 \% \mathrm{CO}_{2}, 95 \%$ air atmosphere. The semi-adherent human colon cancer cells were detached with $0.25 \%$ Trypsin-Versene (EDTA) solution for $5 \mathrm{~min}$ at $37^{\circ} \mathrm{C}$.

A549 human lung adenocarcinoma cell line (ATCC CCL-185) was purchased from LGC Promochem, Teddington, UK. The cells were cultured in Eagle's Minimal Essential Medium (EMEM, Sigma-Aldrich, St Louis, MO, USA) supplemented with $1 \%$ of non-essential amino acid (NEAA) mixture (Sigma-Aldrich, St Louis, MO, USA), 10\% heat-inactivated foetal bovine serum (FBS), $2 \mathrm{mM}$ L-glutamine (Sigma-Aldrich, St Louis, MO, USA), $1 \mathrm{mM}$ Napyruvate (Sigma-Aldrich, St Louis, MO, USA), nystatin (Sigma-Aldrich, St Louis, MO, USA) and a penicillin-streptomycin mixture (Sigma-Aldrich, St Louis, MO, USA) in concentrations of $100 \mathrm{U} / \mathrm{L}$ and $10 \mathrm{mg} / \mathrm{L}$, respectively. The cell lines were incubated at $37^{\circ} \mathrm{C}$, in a $5 \% \mathrm{CO}_{2}, 95 \%$ air atmosphere.

NIH/3T3 mouse embryonic fibroblast cell line (ATCC CRL-1658) was purchased from LGC Promochem, Teddington, UK. The cell line was cultured in Dulbecco's Modified Eagle's Medium (DMEM; Gibco Life Technologies Co., UK), containing $4.5 \mathrm{~g} / \mathrm{L}$ glucose, supplemented with 10\% heat-inactivated foetal bovine serum (FBS), $2 \mathrm{mM}$ L-glutamine (Sigma-Aldrich, St Louis, MO, USA), 1 mM Na-pyruvate (Sigma-Aldrich, St Louis, MO, USA), nystatin (Sigma-Aldrich, St Louis, MO, USA) and a penicillin-streptomycin mixture (Sigma-Aldrich, St Louis, MO, USA) in concentrations of $100 \mathrm{U} / \mathrm{L}$ and $10 \mathrm{mg} / \mathrm{L}$, respectively. The cell lines were incubated at $37^{\circ} \mathrm{C}$, in a $5 \% \mathrm{CO}_{2}, 95 \%$ air atmosphere.

MRC-5 human embryonic lung fibroblast cell line (ATCC CCL-171) were purchased from LGC Promochem, Teddington, UK. The cell line was cultured in Eagle's Minimal Essential Medium (EMEM, Sigma-Aldrich, St Louis, MO, USA) supplemented with a non-essential amino acid (NEAA) mixture (Sigma-Aldrich, St Louis, MO, USA), a selection of vitamins, 10\% heat-inactivated foetal bovine serum (FBS), $2 \mathrm{mM}$ L-glutamine (Sigma-Aldrich, St Louis, MO, USA), 1 mM Na-pyruvate (Sigma-Aldrich, St Louis, MO, USA), nystatin (Sigma-Aldrich, St Louis, MO, USA) and a penicillin-streptomycin mixture (Sigma-Aldrich, St Louis, MO, USA) in concentrations of $100 \mathrm{U} / \mathrm{L}$ and $10 \mathrm{mg} / \mathrm{L}$, respectively. The cell lines were incubated at $37^{\circ} \mathrm{C}$, in a $5 \% \mathrm{CO}_{2}, 95 \%$ air atmosphere. 


\section{Assay for cytotoxic effect}

The effects of increasing concentrations of the compounds on cell growth were tested in 96-well flat-bottomed microtiter plates. The two-fold serial dilutions of the tested compounds were made starting in the third row of the 96 -well microtiter plate $(4 \mu \mathrm{L}$ of the $10 \mathrm{mM}$ stock solutions were added to $196 \mu \mathrm{L}$ of medium, then diluted in the respective wells). Then, $10^{4}$ of mouse T-cell lymphoma and human colonic adenocarcinoma cells in $100 \mu \mathrm{L}$ of the corresponding medium were added to each well, except for the medium control wells, resulting in a final concentration of $100 \mu \mathrm{M}$. The adherent mouse embryonic fibroblast cells $\left(10^{4} /\right.$ well $)$, human lung fibroblast cells $\left(1,5 \times 10^{4} /\right.$ well $)$ and human lung adenocarcinoma cells $\left(10^{4} /\right.$ well $)$ were seeded in the corresponding medium in 96-well flat-bottomed microtiter plates for 4 hours before the assay. The serial dilutions of the compounds were made in a separate plate, and then transferred to the plates containing the corresponding adherent cell line.

The culture plates were incubated at $37^{\circ} \mathrm{C}$ for $24 \mathrm{~h}$; at the end of the incubation period, $20 \mu \mathrm{L}$ of MTT (thiazolyl blue tetrazolium bromide, Sigma) solution (from a $5 \mathrm{mg} / \mathrm{mL}$ stock solution) were added to each well [158]. After incubation at $37^{\circ} \mathrm{C}$ for $4 \mathrm{~h}, 100 \mu \mathrm{L}$ of sodium dodecyl sulfate (SDS) (Sigma) solution $(10 \%$ SDS in $0.01 \mathrm{M} \mathrm{HCl})$ were added to each well and the plates were further incubated at $37^{\circ} \mathrm{C}$ overnight. Cell growth was determined by measuring the optical density (OD) at $550 \mathrm{~nm}($ ref. $630 \mathrm{~nm}$ ) with Multiscan EX ELISA reader (Thermo Labsystems, Cheshire, WA, USA) (Appendix 6.). Inhibition of cell growth was expressed as $\mathrm{IC}_{50}$ values, defined as the inhibitory dose that reduces the growth of the cells exposed to the tested compounds by $50 \%$, determined according to the formula below:

$$
\mathrm{IC}_{50}=100-\left[\frac{\text { OD sample }- \text { OD medium control }}{\text { OD cell control }- \text { OD medium control }}\right] \times 100
$$

A control experiment was performed with each tested compound with the same experimental setup without cells, to assess whether there are any redox-interactions with the MTT dye, which could potentially lead to color change. No such interactions with MTT were observed. Cisplatin (from a $0.5 \mathrm{mg} / \mathrm{mL}$ stock solution) was used as positive control, as it is routinely administered in clinical practice for the treatment of hematological malignancies and of solid tumors such as lung and colon cancer [5]. The solvent (DMSO) did not have any effect on the cell growth in the tested concentrations.

Selectivity indices (SI) were calculated to determine the potency of the tested compounds towards the tumoral and non-malignant cell lines, respectively. The SI values were calculated as a quotient of the $\mathrm{IC}_{50}$ values in the non-tumoral cells divided by the $\mathrm{IC}_{50}$ values in the (sensitive or MDR, where applicable) cancer cell lines. The compounds are considered as strongly selective if the SI values are higher than 6, moderately selective if $3<$ SI $<6$, slightly selective if $1<\mathrm{SI}<3$ and non-selective if the SI values are lower than 1 [159]. 


\section{Assay for the inhibition of the ABCB1 efflux pump}

The inhibition of the cancer multidrug efflux pump ABCB1 by the tested compounds was evaluated using flow cytometry, measuring the retention of rhodamine 123 by ABCB1 (Pglycoprotein) in MDR mouse T-lymphoma cells and Colo320 colonic adenocarcinoma cells, as both cell lines overexpress the ABCB1 transporter (P-glycoprotein) [160]. This method is a fluorescence-based detection system which uses verapamil (a first-generation, competitive EPI) as reference inhibitor [161]. Briefly, cell number of mouse T-lymphoma and colonic adenocarcinoma cells were adjusted to $2 \times 10^{6}$ cells $/ \mathrm{mL}$, re-suspended in serum-free McCoy's 5A medium in case of mouse T-lymphoma cells and serum-free RPMI-1640 medium in case of colonic adenocarcinoma cells and distributed in $0.5 \mathrm{~mL}$ aliquots into Eppendorf centrifuge tubes. The tested compounds were added at different concentrations ( 2 and $20 \mu \mathrm{M}$; from 1 and $10 \mathrm{mM}$ stock solutions, respectively) and the samples were incubated for 10 minutes at room temperature. Verapamil (EGIS Hungarian Pharmaceutical Company, Budapest, Hungary) was applied as positive control ( $20 \mu \mathrm{M}$ final concentration) and DMSO was used as solvent control (at $2 \mathrm{~V} / \mathrm{V} \%$ ) [160]. Next, $10 \mu \mathrm{L}(5.2 \mu \mathrm{M}$ final concentration) of the fluorochrome rhodamine 123 (Sigma, St. Louis, MO, USA) was added to the samples and the cells were incubated for 20 minutes at $37^{\circ} \mathrm{C}$.

Rhodamine 123 (R123) is a non-toxic, lipophilic, cationic fluorescent dye $\left(\lambda_{\text {ex } / \mathrm{em}}=505 / 534 \mathrm{~nm}\right)$, which is a substrate of the ABCB1 transporter (Appendix 6.). As the compound is membrane-permeable, it is rapidly taken up by the cells, therefore it can be effectively used for the screening of efflux pump inhibiting compounds [161]. After the incubation period, the cells were washed twice and re-suspended in $0.5 \mathrm{~mL} \mathrm{PBS}$ for analysis.

The fluorescence of the gated cell population was measured with a Partec CyFlow ${ }^{\circledR}$ flow cytometer (Partec, Münster, Germany). The percentage of mean fluorescence intensity was calculated for the treated MDR cells as compared with the untreated cells. The results were obtained from a representative flow cytometry experiment in which at least 20,000 individual cells of the overall population were evaluated for the rhodamine 123 retained inside the cells. The fluorescence activity ratio (FAR) was calculated based on the following equation which relates the measured fluorescence values:

$$
\mathrm{FAR}=\frac{\mathrm{MDR} \text { treated } / \mathrm{MDR} \text { control }}{\text { parental treated } / \text { parental } \text { control }_{\text {par }}}
$$

Parameters evaluated from flow cytometric experiments were: Forward Scatter Count (FSC, provides information about cell size); Side Scatter Count (SSC, proportional to cell granularity or internal complexity); FL-1 (Mean fluorescence of the cells) and Fluorescence Activity Ratio (FAR), which was calculated by the equation given above. The efflux pump inhibitory activity of the tested compounds was compared to the activity of verapamil, additionally, a FAR-quotient was calculated, according to the following equation:

$$
\text { Quotient }=100 \times\left(\mathrm{FAR}_{\text {compound }} / \mathrm{FAR}_{\text {verapamil }}\right)
$$




\section{E. Assay for apoptosis induction}

The capacity of the selenocompounds to induce apoptosis was investigated by using L5178Y mouse T-cell lymphoma cells (parental and $A B C B 1$-transfected) as well as multidrug resistant (MDR) Colo 320 colonic adenocarcinoma cells as in vitro model systems. The apoptosis induction assays were performed using Calbiochem Annexin V-FITC Apoptosis Detection Kit, following the manufacturer's instructions. This method enables the quantification and differentiation of early and late apoptotic events as well as necrosis and cell death in the cell population exposed to the respective selenocompounds [164]. In the assay, Annexin $\mathrm{V}$ was used as phospholipid binding protein, to which fluorescein isothiocyanate (FITC) was conjugated as a fluorescent substrate $\left(\lambda_{\mathrm{ex} / \mathrm{em}}=495 / 519 \mathrm{~nm}\right)$ (Appendix 7.) [162]. Because the Annexin-FITC conjugate also binds to the externalized phosphatidyl serine of the necrotic cells, propidium iodide (PI; $\lambda_{\text {ex/em }}=535 / 617 \mathrm{~nm}$ ) staining was used to detect cells in distinct stages of cell death $[103,163]$. These two stains can be used in parallel in this fashion, because they don't have overlapping wavelength ranges (Table 2.) [33].

Table 2: Differentiation of cells in distinct stages of cell death with Annexin V-propidium iodide double staining, using flow cytometry [34]

\begin{tabular}{lll}
\hline Condition of cells & Annexin-FITC & Propidium iodide \\
Healthy, living & Negative & Negative \\
Early apoptotic & Positive & Negative \\
Late apoptotic, necrotic & Positive & Positive \\
Cell death & Negative & Positive \\
\hline
\end{tabular}

The concentration of the cell suspension was adjusted to $1 \times 10^{6}$ cells $/ \mathrm{mL}$. The L5178Y mouse T-cell lymphoma cell suspension was distributed into $0.5 \mathrm{~mL}$ aliquots $\left(5 \times 10^{5}\right.$ cells $)$ to Eppendorf tubes. The mouse T-lymphoma cells were then incubated in the presence of the compounds for $1 \mathrm{~h}$ at $37^{\circ} \mathrm{C}$. In case of the Colo 320 cell line, the cell suspension was distributed to 24 -well plate and incubated overnight at $37^{\circ} \mathrm{C}$ in $5 \% \mathrm{CO}_{2}$ incubator. On the following day, the medium was removed, and fresh medium was added to the cells containing the tested compounds. The incubation period for colonic adenocarcinoma cells in the presence of the compounds was $3 \mathrm{~h}$. $12 \mathrm{H}$-benzo[ $\alpha$ ]phenothiazine M627 was used as positive control at the final concentration of $20 \mu \mathrm{M}$, which is a known early apoptosis inducer, whereas DMSO was used as solvent control (at $2 \mathrm{~V} / \mathrm{V} \%$ ) [164,165]. The samples were washed in PBS and the harvested cells were centrifuged at $2000 \times \mathrm{g}$ for 2 minutes. Fresh medium was added to the cells, followed by the overnight incubation of the plate at $37^{\circ} \mathrm{C}$, in $5 \% \mathrm{CO}_{2}$ atmosphere. After the incubation period, the Colo 320 cells were removed gently from the wells using a cell scraper. Following this step, the apoptosis assay was carried out according to the "rapid" protocol of the kit, and the fluorescence was analyzed immediately using a ParTec CyFlow flow cytometer (Partec, Munster, Germany). 


\section{F. Predictive in silico assay}

A preliminary in silico assay was performed using the freely accessible software packages OSIRIS Molecular Property Explorer (Actelion Pharmaceuticals, Allschwil, Switzerland) and PreADMET 2.0 (Yonsei University, Seoul, Republic of Korea) to predict the physico-chemical and in vivo absorption properties of the tested compounds [166,167]. OSIRIS works with a database of 2000-5000 drug molecules (depending on the model in question), while PreADMET 2.0 contains the experimentally measured physico-chemical attributes of more than 1 million molecules $[168,169]$. The following properties of the tested compounds were assessed to verify their conformity with Lipinsky's Rule of Five (RO5) [170,171]: molecular weight $(M)$ [172], number of hydrogen bond donors (n-OHNH), number of hydrogen bond acceptors (n-ON) [171,173], base 10 logarithm of the octanol/water partition coefficient $(c \log P)$ [174,175], base $10 \operatorname{logarithm}$ of water solubility ( $\log S$; expressed as $\mathrm{mol} / \mathrm{L}$ ) [175] and topological polar surface area of the molecules (TPSA) [176-179] (see detailed description of criteria in Appendix 8.). Additionally, the programs were used to predict the pharmacokinetic (i.e., ADME) properties of the tested compounds, such as the percentage of plasma protein binding (PPB\%) [179], permeability on different model systems of cellular monolayers (Caco-2, MDCK) [180,181], percentage of human intestinal absorption (HIA\%) [180,182] and interaction with various cytochrome P450 enzymes [183]. To compare our data to clinically relevant anticancer agents, various, structurally and functionally different chemotherapeutic drugs (doxorubicin, gemcitabine, irinotecan, methotrexate and 5fluorouracil) were chosen as references.

Additionally, a correlation-regression analysis was performed with the aim of assessing the relationship between the measured fluorescence ratios (i.e. efflux pump inhibitory activity) on mouse T-lymphoma and colonic adenocarcinoma cells and selected physico-chemical properties (M, cLogP, $\log$ S and $\log$ TPSA) [184]. The statistical analyses were performed using Past 3.16 statistical software: $\mathrm{p}<0.05$ was considered statistically significant, furthermore the coefficient of determination $\left(\mathrm{R}^{2}\right)$ was also calculated, which shows percentage variation in FAR values which is explained by the respective physico-chemical parameters [184-186]. 


\section{RESULTS}

\section{A. Cytotoxicity assay}

Eleven selenocompounds (1-11) and four reference compounds (12-15) were evaluated for their cytotoxic activity against various cell lines of murine and human origin. The results presented in Tables 3-4. (and Appendix 9-10., with SD data) are derived from three independent experiments carried out under identical conditions. For compounds where the calculated $\mathrm{IC}_{50}$ values were greater than $100 \mu \mathrm{M}$ were not considered effective and the selectivity indices could not be determined either. The reference compounds (12-15) did not have cytotoxic activity on any of the tested cell lines.

Table 3. Cytotoxic activity and selectivity of the tested compounds against various cell lines of murine origin

\begin{tabular}{|c|c|c|c|c|c|c|}
\hline Sample & $\begin{array}{c}\text { A: PAR } \\
\text { mouse T- } \\
\text { lymphoma } \\
\mathrm{IC}_{50}(\mu \mathrm{M})\end{array}$ & $\begin{array}{c}\text { B: MDR } \\
\text { mouse T- } \\
\text { lymphoma } \\
\mathrm{IC}_{50}(\mu \mathrm{M})\end{array}$ & SI (A/B) & $\begin{array}{c}\text { C: } \\
\text { NIH/3T3 } \\
\text { mouse } \\
\text { fibroblast } \\
\text { IC }_{50}(\mu M) \\
\end{array}$ & SI (C/A) & $\mathrm{SI}(\mathrm{C} / \mathrm{B})$ \\
\hline 1 & 3.97 & 4.65 & 0.85 & $>100$ & $\geq 25.19$ & $\geq 21.51$ \\
\hline 2 & $>100$ & $>100$ & - & 23.72 & $\leq 0.24$ & $\leq 0.24$ \\
\hline 3 & 19.50 & 16.90 & 1.15 & $>100$ & $\geq 5.13$ & $\geq 5.92$ \\
\hline 4 & $>100$ & $>100$ & - & $>100$ & - & - \\
\hline 5 & $>100$ & $>100$ & - & $>100$ & - & - \\
\hline 6 & $>100$ & 36.4 & $\geq 2.75$ & 69.69 & $\leq 0.70$ & 1.91 \\
\hline 7 & $>100$ & 87.8 & $\geq 1.14$ & 23.72 & $\leq 0.24$ & 0.27 \\
\hline 8 & $>100$ & $>100$ & - & 74.47 & $\leq 0.74$ & $\leq 0.74$ \\
\hline 9 & 0.78 & 1.03 & 0.76 & 0.62 & 0.79 & 0.61 \\
\hline 10 & 0.94 & 0.43 & 2.19 & 1.35 & 1.44 & 3.14 \\
\hline 11 & 1.31 & 0.97 & 1.35 & 0.82 & 0.63 & 0.85 \\
\hline 12 & $>100$ & $>100$ & - & $>100$ & - & - \\
\hline 13 & $>100$ & $>100$ & - & $>100$ & - & - \\
\hline 14 & $>100$ & $>100$ & - & $>100$ & - & - \\
\hline 15 & $>100$ & $>100$ & - & $>100$ & - & - \\
\hline Cisplatin & 4.87 & 16.65 & 0.29 & 11.16 & 2.29 & 0.67 \\
\hline DMSO & $>2 \mathrm{~V} / \mathrm{V} \%$ & $>2 \mathrm{~V} / \mathrm{V} \%$ & & $>2 \mathrm{~V} / \mathrm{V} \%$ & - & - \\
\hline
\end{tabular}

$\mathrm{IC}_{50}$ : the inhibitory dose that reduces the growth of the cells exposed to the tested compounds by 50\%; SI: selectivity index; DMSO: dimethyl sulfoxide

Values in boldface letters represent compounds with pronounced cytotoxic activity and/or selectivity.

The cyclic selenoanhydride (1) and the selenoesters (9-11) exerted remarkable cytotoxic activity on both the parental and multidrug resistant cell lines $(0.94-3.97 \mu \mathrm{M}$ and 0.43-4.65 $\mu \mathrm{M}$, respectively), the latter three compounds were proven to be cytotoxic in nanomolar range, the $\mathrm{IC}_{50}$ value for the most active selenoester (10) was $430 \mathrm{nM}$ in MDR cells. Compounds 3 and $\mathbf{6}$ also presented with strong cytotoxicity, but they exhibited their activity in concentrations 5-40 times higher, than the previous four compounds. 
Selenoesters 9-11 also proved to be toxic on non-tumoral mouse embryonic fibroblast cells at low concentrations ( $\mathrm{IC}_{50}: 0.62-1.35 \mu \mathrm{M}$ ), while compounds 2 and 7 ( $\mathrm{IC}_{50}: 23.72 \mu \mathrm{M}$ ), and 6 and 8 (IC I0: 69.69 and $74.47 \mu \mathrm{M}$ ) exhibited toxic properties in similar concentrations. Compound 10 was moderately selective $(\mathrm{SI}=3.14)$, while the selenoanhydride showed excellent ( $\mathrm{SI} \geq 25.19$ ) selectivity towards the cancerous cell lines. The cytotoxic activity of the positive control cisplatin on murine cell lines was superior to the reference compounds (12-15) and selenoesters 2-8, while it was less potent than compounds $\mathbf{1}$ and 9-11 in respect to their $\mathrm{IC}_{50}$ values and to compounds $\mathbf{1}, \mathbf{3}$, and $\mathbf{1 0}$ when SI values were compared (Table 3., Appendix 9., with SD data).

Table 4. Cytotoxic activity and selectivity of the tested compounds against various cell lines of human origin

\begin{tabular}{|c|c|c|c|c|c|c|c|c|}
\hline Sample & $\begin{array}{c}\text { A: } \\
\text { Colo } 205 \\
\text { colon } \\
\text { adenocarc. } \\
\text { IC }_{50}(\mu \mathrm{M})\end{array}$ & $\begin{array}{c}\text { B: } \\
\text { Colo } 320 \\
\text { colon } \\
\text { adenocarc. } \\
\text { IC }_{50}(\mu \mathrm{M})\end{array}$ & $\begin{array}{c}\mathbf{S I} \\
(\mathbf{A} / \mathbf{B})\end{array}$ & $\begin{array}{c}\text { C: } \\
\text { A549 lung } \\
\text { adenocarc. } \\
\text { IC }_{50}(\mu \mathrm{M})\end{array}$ & $\begin{array}{c}\text { D: } \\
\text { MRC-5 } \\
\text { lung } \\
\text { fibroblast } \\
\text { IC }_{50}(\boldsymbol{\mu M})\end{array}$ & $\begin{array}{c}\text { SI } \\
(\mathbf{D} / \mathbf{A})\end{array}$ & $\begin{array}{c}\text { SI } \\
(\mathbf{D} / \mathbf{B})\end{array}$ & $\begin{array}{c}\text { SI } \\
(\mathbf{D} / \mathrm{C})\end{array}$ \\
\hline 1 & $>100$ & 63.90 & $\geq 1.6$ & $>100$ & $>100$ & - & $\geq 1.6$ & - \\
\hline 2 & $>100$ & $>100$ & - & 49.30 & 4.26 & $\leq 0.04$ & $\leq 0.04$ & 0.09 \\
\hline 3 & $>100$ & $>100$ & - & $>100$ & 17.90 & $\leq 0.18$ & $\leq 0.18$ & $\leq 0.18$ \\
\hline 4 & $>100$ & 12.50 & $\geq 8.0$ & $>100$ & 28.40 & $\leq 0.28$ & 2.30 & $\leq 0.28$ \\
\hline 5 & $>100$ & $>100$ & - & $>100$ & 61.50 & $\leq 0.62$ & $\leq 0.62$ & $\leq 0.62$ \\
\hline 6 & $>100$ & $>100$ & - & $>100$ & 76.6 & $\leq 0.77$ & $\leq 0.77$ & $\leq 0.77$ \\
\hline 7 & $>100$ & $>100$ & - & $>100$ & 33.40 & $\leq 0.33$ & $\leq 0.33$ & $\leq 0.33$ \\
\hline 8 & $>100$ & 53.70 & $\geq 1.90$ & 51.20 & $>100$ & - & $\geq 1.9$ & 1.95 \\
\hline 9 & 5.48 & 0.55 & 10.0 & 5.91 & 5.35 & 0.98 & 9.70 & 0.91 \\
\hline 10 & 1.63 & 0.96 & 1.70 & 9.10 & 8.10 & 5.00 & 8.40 & 0.89 \\
\hline 11 & 1.19 & 0.35 & 3.40 & 15.22 & 5.04 & 4.20 & 14.40 & 0.33 \\
\hline 12 & $>100$ & $>100$ & - & $>100$ & $>100$ & - & - & - \\
\hline 13 & $>100$ & $>100$ & - & $>100$ & $>100$ & - & - & - \\
\hline 14 & $>100$ & $>100$ & - & $>100$ & $>100$ & - & - & - \\
\hline 15 & $>100$ & $>100$ & - & $>100$ & $>100$ & - & - & - \\
\hline Cisplatin & 62.26 & 37.90 & 1.64 & 3.63 & 33.45 & 0.54 & 0.88 & 9.21 \\
\hline DMSO & $>2 \mathrm{~V} / \mathrm{V} \%$ & $>2 \mathrm{~V} / \mathrm{V} \%$ & - & $>2$ V/V\% & $>2 \mathrm{~V} / \mathrm{V} \%$ & - & - & - \\
\hline
\end{tabular}

$\mathrm{IC}_{50}$ : the inhibitory dose that reduces the growth of the cells exposed to the tested compounds by $50 \%$; SI: selectivity index; DMSO: dimethyl sulfoxide

Values in boldface letters represent compounds with pronounced cytotoxic activity and/or selectivity.

The assays on human colonic adenocarcinoma cells showed that selenoesters 9-11 had strong cytotoxic effect on both the sensitive (Colo 205) and multidrug resistant colonic adenocarcinoma (Colo 320) cell lines ( $\mathrm{IC}_{50}: 1.19-5.48 \mu \mathrm{M}$ and 0.35-0.96 $\mu \mathrm{M}$, respectively), the $\mathrm{IC}_{50}$ value for the most active selenoester (11) was $350 \mathrm{nM}$ in Colo 320 cells. It is worth noting that selenoesters 9 and $\mathbf{1 1}$ demonstrated moderate-strong selectivity (SI: 3.40-10.0) towards the Colo 320 cell line and colonic adenocarcinoma cells (SI: 4.2-14.40). The cyclic selenoanhydride and two other selenoesters ( $\mathbf{4}$ and $\mathbf{8}$ ) were similarly promising, as they did not show cytotoxic activity on the Colo 205 cell line, but exerted activity on the resistant cells, although in higher concentrations that would be expected of such compounds. The $\mathrm{IC}_{50}$ values of cisplatin were 11.36-108.29-times higher than that of selenoesters 9-11 and the selenocompounds were 2.07-6.09-times more selective towards colonic adenocarcinoma cells (Table 4., Appendix 10., with SD data). 
Similarly, selenocompounds 9-11 proved to be potent cytotoxic agents on A549 lung carcinoma cells $\left(\mathrm{IC}_{50}\right.$ : 5.91-15.22 $\left.\mu \mathrm{M}\right)$, together with two other compounds ( 2 and 8 ) which were cytotoxic at approximately $50 \mu \mathrm{M}$. However, the compounds showed slight or no selectivity (0.09-1.95) in respect to cytotoxic and selective in case of lung adenocarcinoma cells (IC50: $3.63 \mu \mathrm{M}$; SI: 9.21) (Table 4., Appendix 10., with SD data).

\section{B. Inhibition of the ABCB1 efflux pump}

The aim of the study was to determine the efflux pump inhibitory activity of the compounds on multidrug resistant mouse T-lymphoma and Colo 320 colonic adenocarcinoma cells, since they overexpress the human $\mathrm{ABCB} 1$ transporter, which may be responsible for the multidrug resistant phenotype by expelling anticancer agents from the cytoplasm of the cell. Because inhibitors of these proteins may reverse the MDR phenotype of cancer cells, the coadministration of EPIs with anti-neoplastic agents is a promising therapeutic strategy. In the experiment, the calculated fluorescence activity ratios (FAR) were compared, which is directly proportional to the intracellular accumulation of rhodamine 123 (Figure 10-12.).

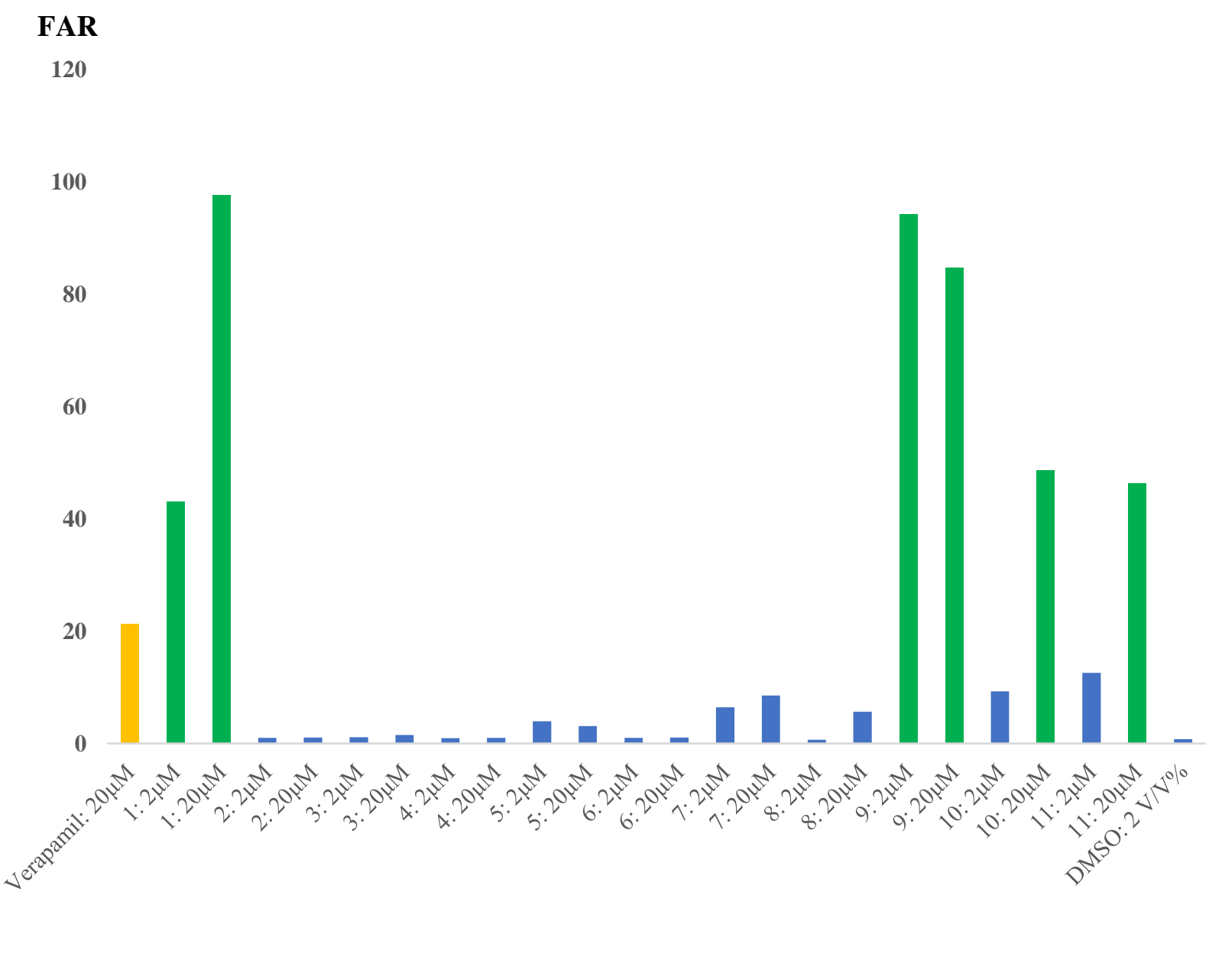

Figure 10. Efflux pump inhibitory activity of selenocompounds on MDR mouse T-lymphoma cells in 2 and $20 \mu \mathrm{M}$ concentrations

(FAR: fluorescence activity ratio; DMSO: dimethyl sulfoxide) 
Four derivatives $(\mathbf{1}, \mathbf{9 - 1 1})$ out of the eleven compounds exhibited potent ABCB1 inhibitory activity (the intracellular concentration of R123 was the highest) on the MDR mouse Tlymphoma and Colo 320 colonic adenocarcinoma cell lines at $20 \mu \mathrm{M}$ concentration (Figure 10. and 12.). The FAR quotients of the active compounds (1, 9-11) were 217.71-458.48\% compared to the positive control's (verapamil, $20 \mu \mathrm{M}$ ) activity on the MDR lymphoma cells (FAR=21.29). Interestingly, the two most active compounds (cyclic selenoanhydride $\mathbf{1}$ and selenoester 9) were more potent inhibitors of ABCB1 than verapamil in concentrations ten times lower ( 20 vs. $2 \mu \mathrm{M}$ ), with quotient values of $202.58 \%$ and $442.41 \%$ at $2 \mu \mathrm{M}$, respectively (Appendix 11.).

Comparable results were observed on the ABCB1-overexpressing Colo 320 cells: the cyclic selenoanhydride 1 and selenoesters 9-11 proved to be promising inhibitors of the transporter protein, outperforming verapamil (FAR=2.85) in $2 \mu \mathrm{M}$ concentration (quotients ranging from 135.44-401.05\%) (Figure 11.). Selenoesters 9-11 were not tested at $20 \mu \mathrm{M}$ on colonic adenocarcinoma cells because of the cytotoxicity of the compounds (Appendix 12.). The other compounds investigated in our study (selenoesters 2-8 and reference compounds 1215) did not show efflux pump inhibitory activity similar to verapamil on either cell lines (Appendix 11-12.).

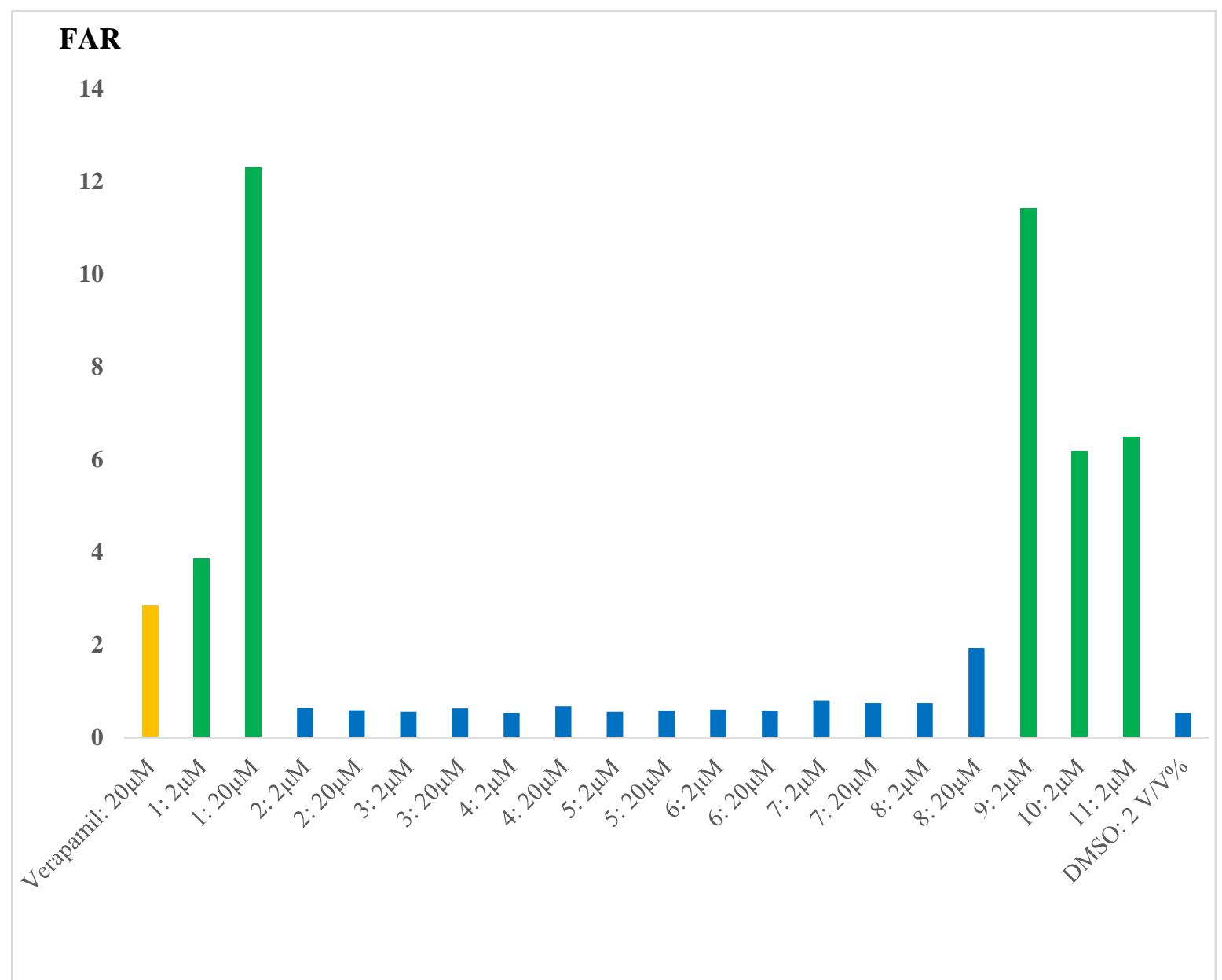

Figure 11. Efflux pump inhibitory activity of selenocompounds on Colo 320 colonic adenocarcinoma cells in 2 and $20 \mu \mathrm{M}$ concentrations

(FAR: fluorescence activity ratio; DMSO: dimethyl sulfoxide) 

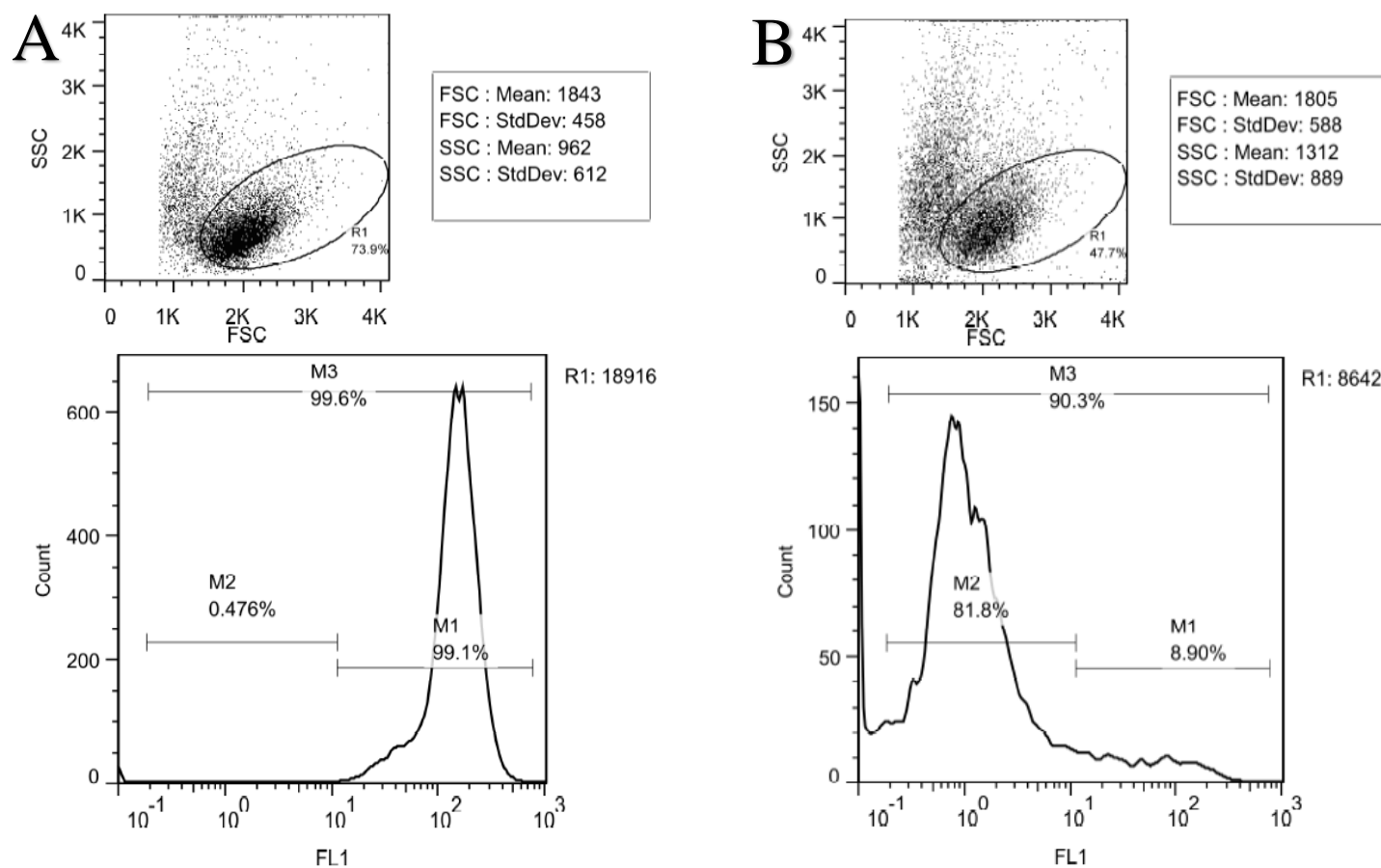

$\mathrm{C}$
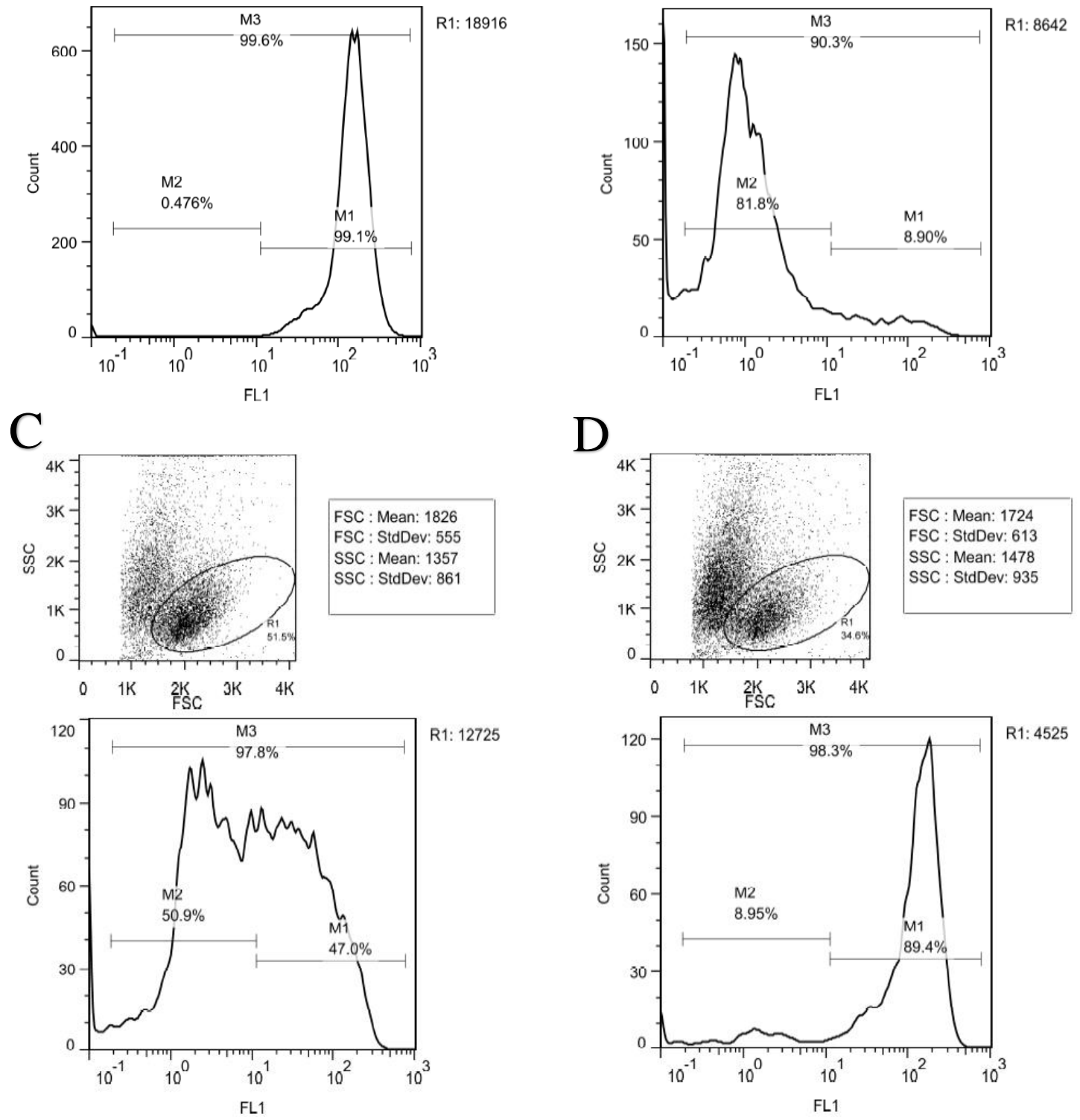

Figure 12. Measured fluorescence intensities from flow cytometry experiments

A: untreated PAR mouse T-lymphoma cells; B: untreated MDR mouse T-lymphoma cells; C: verapamil-treated (20 $\mu \mathrm{M})$ MDR cells; D: compound 1-treated (20 $\mu \mathrm{M})$ MDR cells.

FL1 represents the intracellular fluorescence $(\mathrm{R} 123)$ of cells. 


\section{Apoptosis assay}

The aim of the experiment was to investigate whether the selenocompounds have apoptosisinducing properties on parental and multidrug resistant L5178Y mouse T-lymphoma and multidrug resistant human colon adenocarcinoma cell lines. Their efficacy was compared to the positive control M627 (12H-benzo[ $\alpha]$ phenothiazine (Table 5-7.).

Table 5. Capacity of selenocompounds to induce apoptosis on L5178Y parental mouse T-lymphoma cells

\begin{tabular}{|c|c|c|c|c|c|}
\hline \multirow[b]{2}{*}{ Sample } & \multirow[b]{2}{*}{ Concentration $(\boldsymbol{\mu M})$} & \multicolumn{4}{|c|}{ Percentage of gated events } \\
\hline & & $\begin{array}{c}\text { Early } \\
\text { apoptosis } \\
(\%)\end{array}$ & $\begin{array}{c}\text { Late } \\
\text { apoptosis, } \\
\text { necrosis } \\
(\%)\end{array}$ & $\begin{array}{c}\text { Cell } \\
\text { death } \\
(\%)\end{array}$ & $\begin{array}{c}\text { Total } \\
\text { apoptotic } \\
\text { events } \\
(\%)\end{array}$ \\
\hline A- I- & - & 0.22 & 0.00 & 0.00 & 0.22 \\
\hline A- I+ & - & 0.09 & 1.14 & 1.55 & 2.78 \\
\hline $\mathbf{A}+\mathbf{I}-$ & - & 4.27 & 0.02 & 0.00 & 7.52 \\
\hline$A+I+$ & - & 2.60 & 0.82 & 0.12 & 3.54 \\
\hline DMSO & $2 \mathrm{~V} / \mathrm{V} \%$ & 3.96 & 0.86 & 0.19 & 5.01 \\
\hline M627 & 20 & 51.20 & 5.58 & 0.28 & 57.06 \\
\hline 1 & 2 & 31.50 & 53.90 & 0.77 & 86.17 \\
\hline 2 & 2 & 6.64 & 6.93 & 0.35 & 13.92 \\
\hline 3 & 2 & 5.97 & 7.18 & 0.20 & 13.35 \\
\hline 4 & 2 & 4.47 & 3.79 & 0.08 & 8.34 \\
\hline 5 & 2 & 3.61 & 2.01 & 0.11 & 5.73 \\
\hline 6 & 2 & 2.46 & 2.24 & 0.08 & 4.78 \\
\hline 7 & 2 & 5.09 & 2.52 & 0.50 & 8.11 \\
\hline 8 & 2 & 3.00 & 2.11 & 0.24 & 5.35 \\
\hline 9 & 2 & 30.80 & 52.70 & 0.87 & 84.37 \\
\hline 10 & 2 & 36.10 & 56.10 & 0.26 & 92.46 \\
\hline 11 & 2 & 15.70 & 66.60 & 0.17 & 82.47 \\
\hline 12 & 2 & 0.10 & 0.28 & 0.23 & 0.61 \\
\hline 13 & 2 & 0.12 & 0.19 & 0.60 & 0.91 \\
\hline 14 & 2 & 0.43 & 0.63 & 1.00 & 2.06 \\
\hline 15 & 2 & 0.18 & 0.90 & 1.01 & 2.09 \\
\hline
\end{tabular}

A- I-: annexin negative/propidium-iodide negative; A- I-: annexin negative/propidium-iodide positive; A- I-: annexin positive/propidium-iodide negative; A- I-: annexin positive/propidium-iodide positive.

Values in boldface letters represent compounds with pronounced apoptosis inducing properties.

The tested selenocompounds were effective apoptosis-inducers on the murine cell lines. In general, the cyclic selenoanhydride (1) and the selenoesters (9-11) were the most potent derivatives, compared to the positive control (M627) when considering the total percentage of apoptotic events. It should also be noted that M627 only matched the activity of the abovementioned compounds at ten times higher concentrations ( 2 vs. $20 \mu \mathrm{M}$ ) (Table 5., Figure 13.). 
Table 6. Capacity of selenocompounds to induce apoptosis on L5178Y MDR ABCB1-overexpressing mouse T-lymphoma cells

\begin{tabular}{|c|c|c|c|c|c|}
\hline \multirow[b]{2}{*}{ Sample } & \multirow[b]{2}{*}{ Concentration $(\boldsymbol{\mu M})$} & \multicolumn{4}{|c|}{ Percentage of gated events } \\
\hline & & $\begin{array}{c}\text { Early } \\
\text { apoptosis }(\%)\end{array}$ & $\begin{array}{c}\text { Late apoptosis, } \\
\text { necrosis } \\
(\%)\end{array}$ & $\begin{array}{c}\text { Cell } \\
\text { death } \\
(\%)\end{array}$ & $\begin{array}{c}\text { Total } \\
\text { apoptotic } \\
\text { events } \\
(\%)\end{array}$ \\
\hline A-I- & - & 0.00 & 0.00 & 0.00 & 0.00 \\
\hline A- I+ & - & 0.02 & 0.01 & 2.18 & 2.21 \\
\hline $\mathbf{A}+\mathbf{I}-$ & - & 4.35 & 0.00 & 0.00 & 4.35 \\
\hline $\mathbf{A}+\mathbf{I}+$ & - & 2.20 & 1.57 & 0.03 & 3.80 \\
\hline DMSO & $2 \mathrm{~V} / \mathrm{V} \%$ & 6.46 & 1.57 & 0.09 & 8.83 \\
\hline M627 & 20 & 47.90 & 45.70 & 0.12 & 93.72 \\
\hline 1 & 2 & 32.20 & 45.00 & 0.47 & 77.67 \\
\hline 2 & 2 & 5.07 & 2.34 & 0.30 & 7.71 \\
\hline 3 & 2 & 5.38 & 3.28 & 0.24 & 8.90 \\
\hline 4 & 2 & 4.35 & 2.80 & 0.45 & 7.60 \\
\hline 5 & 2 & 3.01 & 3.25 & 0.37 & 6.63 \\
\hline 6 & 2 & 3.01 & 2.91 & 0.33 & 6.25 \\
\hline 7 & 2 & 2.69 & 1.47 & 0.03 & 4.19 \\
\hline 8 & 2 & 3.90 & 2.26 & 0.16 & 6.32 \\
\hline 9 & 2 & 3.86 & 85.80 & 7.66 & 97.32 \\
\hline 10 & 2 & 15.90 & 21.90 & 1.21 & 39.01 \\
\hline 11 & 2 & 16.60 & 30.50 & 0.51 & 47.61 \\
\hline 12 & 2 & 0.04 & 0.14 & 0.06 & 0.24 \\
\hline 13 & 2 & 0.16 & 0.30 & 0.18 & 0.64 \\
\hline 14 & 2 & 0.08 & 0.81 & 0.62 & 1.51 \\
\hline 15 & 2 & 0.32 & 0.56 & 0.24 & 1.12 \\
\hline
\end{tabular}

A- I-: annexin negative/propidium-iodide negative; A- I-: annexin negative/propidium-iodide positive; A- I-: annexin positive/propidium-iodide negative; A- I-: annexin positive/propidium-iodide positive.

Values in boldface letters represent compounds with pronounced apoptosis inducing properties.

In the experiment on multidrug resistant mouse T-lymphoma cells, compound $\mathbf{1}$ had excellent activity, as it induced early apoptosis in $32.2 \%$ of the gated cell population $(77.67 \%$ overall), M627 induced early apoptosis in $47.9 \%$ of the population in a concentration ten times higher. In addition, the selenoesters 9-11 were also effective, although their activity was predominantly detected as late apoptosis/necrosis inducers (Table 6.). The compounds exhibited comparable apoptosis inducing effects on the susceptible (parental) mouse Tlymphoma cells. However, it is of interest that compounds 10-11 were notably more effective on the susceptible cell line (apoptotic events in $39.01 \%$ vs. $84.37 \%$ and $47.16 \%$ vs. $92.46 \%$ of the gated cell population, respectively). The functions of MDR transporter proteins (most notably ABCB1) have been described in apoptosis evasion, mediated by dampening of the extrinsic apoptotic pathway (through suppression of TRAIL protein and caspases 3 and 8) and the stabilization of cell membrane phospholipids (through acting as an outwardly directed flippase) [187]. The inter-relatedness of overexpressed efflux pumps and programmed cell death may explain the results obtained in the apoptosis detection assay. 
Another possible explanation is the lower intracellular concentration of these compounds due to the operation of the $\mathrm{ABCB} 1$ efflux pump: while compounds 9-11 were all cytotoxic ( $\mathrm{IC}_{50}<2 \mu \mathrm{M}$ ), thus contributing to their late apoptosis/necrosis inducing properties on murine cells, selenoester 9 was an effective efflux pump modulator at $2 \mu \mathrm{M}$ concentration, while compounds 10-11 were only effective at $20 \mu \mathrm{M}$. The fact that the compounds exhibited similar percentages of late apoptosis/necrosis on PAR cells, while compound 9 was disproportionally (2.8-3.9-times) more effective on MDR cells further validates this hypothesis (Table 5-6.).
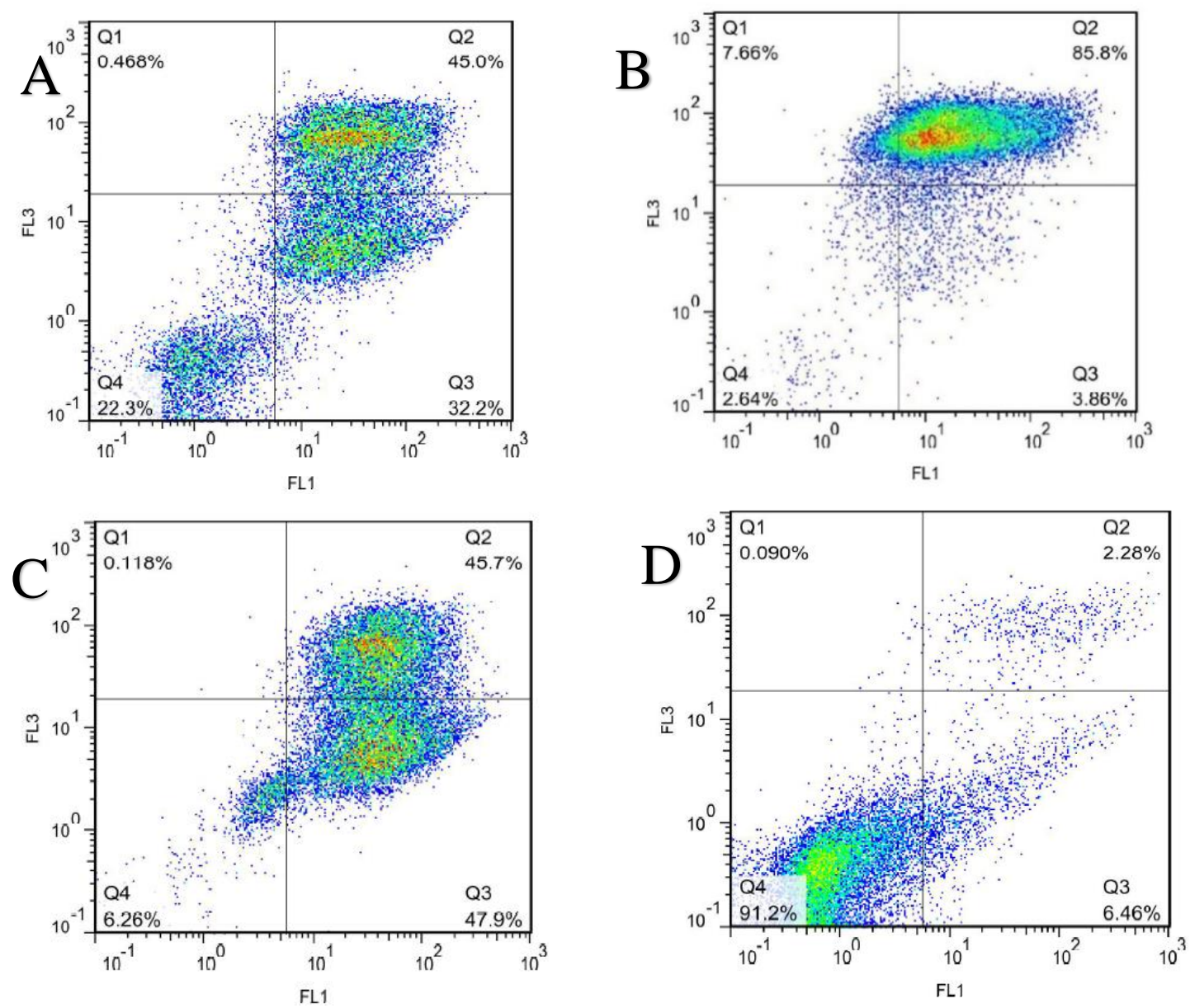

Figure 13. Representative cytograms of the apoptosis assay on MDR mouse T-lymphoma cells; A: compound $1(2 \mu \mathrm{M})$; B: compound $9(2 \mu \mathrm{M})$; C: M627 (20 $\mu \mathrm{M})$; D: DMSO (2 V/V\%)

FL1, FL3: measured fluorescence; Q4: healthy, living cells; Q3: cells undergone early apoptosis; Q2: cells undergone late apoptosis/necrosis; Q1: dead cells (see Appendix 13.)

The compounds $(\mathbf{1}, \mathbf{9 - 1 1})$ showed a similar activity profile for multidrug resistant (Colo 320) human colon adenocarcinoma cells (apoptosis was induced in $64.6-80.5 \%$ of gated cell population overall). The experiment was not performed on the susceptible (Colo 205) subline of colon adenocarcinoma, because of the results obtained in the murine in vitro system (Table 5-7.). Comparing the results on all three cell lines, it can be observed that the cyclic selenoanhydride 1 was a potent inducer of early apoptosis $(32.2-66.1 \%)$, while the active selenoesters (9-11) mainly induced late apoptosis or necrosis, which may be attributed to their strong cytotoxic properties. Considering our results, the selenocompounds exhibited more potent early apoptosis inducing effect in the human colonic adenocarcinoma system (Table 7.). Other selenocompounds (2-8) and reference compounds (12-15) did not have comparable apoptosis inducing properties. 
Table 7. Capacity of selenocompounds to induce apoptosis in Colo 320 MDR colonic adenocarcinoma cells

\begin{tabular}{|c|c|c|c|c|c|}
\hline \multirow[b]{2}{*}{ Sample } & \multirow[b]{2}{*}{ Concentration $(\boldsymbol{\mu M})$} & \multicolumn{4}{|c|}{ Percentage of gated events } \\
\hline & & $\begin{array}{c}\text { Early } \\
\text { apoptosis (\%) }\end{array}$ & $\begin{array}{c}\text { Late apoptosis, } \\
\text { necrosis } \\
(\%)\end{array}$ & $\begin{array}{c}\text { Cell } \\
\text { death } \\
(\%)\end{array}$ & $\begin{array}{c}\text { Total } \\
\text { apoptotic } \\
\text { events } \\
(\%)\end{array}$ \\
\hline A-I- & - & 3.42 & 0.00 & 0.46 & 3.42 \\
\hline A- I+ & - & 2.33 & 0.10 & 0.00 & 2.43 \\
\hline $\mathbf{A}+\mathbf{I}-$ & - & 23.60 & 0.00 & 0.00 & 23.60 \\
\hline$A+I+$ & - & 13.50 & 5.58 & 10.50 & 19.08 \\
\hline DMSO & $2 \mathrm{~V} / \mathrm{V} \%$ & 20.30 & 9.93 & 4.75 & 30.23 \\
\hline M627 & 20 & $\mathbf{5 8 . 5 0}$ & 22.00 & 2.91 & 80.50 \\
\hline 1 & 2 & 66.10 & 5.08 & 1.41 & 71.18 \\
\hline 2 & 2 & 12.00 & 12.50 & 7.56 & 24.50 \\
\hline 3 & 2 & 16.30 & 13.40 & 5.69 & 29.70 \\
\hline 4 & 2 & 13.40 & 15.80 & 6.37 & 29.20 \\
\hline 5 & 2 & 16.20 & 13.50 & 4.93 & 29.70 \\
\hline 6 & 2 & 14.30 & 15.70 & 4.98 & 30.00 \\
\hline 7 & 2 & 20.50 & 14.40 & 5.55 & 34.90 \\
\hline 8 & 2 & 16.00 & 18.60 & 10.40 & 34.60 \\
\hline 9 & 2 & 28.90 & 41.70 & 15.30 & 70.60 \\
\hline 10 & 2 & 28.80 & 35.80 & 15.40 & 64.60 \\
\hline 11 & 2 & 29.70 & 41.70 & 11.60 & 71.40 \\
\hline 12 & 2 & 3.79 & 1.09 & 7.18 & 6.06 \\
\hline 13 & 2 & 4.11 & 1.75 & 7.28 & 7.28 \\
\hline 14 & 2 & 6.07 & 1.62 & 6.98 & 9.55 \\
\hline 15 & 2 & 4.22 & 1.40 & 7.39 & 6.98 \\
\hline
\end{tabular}

A- I-: annexin negative/propidium-iodide negative; A- I-: annexin negative/propidium-iodide positive; A- I-: annexin positive/propidium-iodide negative; A- I-: annexin positive/propidium-iodide positive. Values in boldface letters represent compounds with pronounced apoptosis inducing properties. 


\section{Predictive in silico assay}

As a part of the study, the compliance of compounds to Lipinsky's Rule of Five (RO5) was evaluated. The predicted physico-chemical parameters of the tested compounds are presented in Table 8. The selenocompounds are in accordance with the evaluation criteria detailed in Appendix 8., regarding their physico-chemical properties, and they all complied with the Rule of Five without exception, as opposed to certain reference compounds (doxorubicin, methotrexate, irinotecan).

Table 8. Predicted physico-chemical properties of the tested selenocompounds and reference chemotherapeutic agents

\begin{tabular}{|c|c|c|c|c|c|c|c|}
\hline Compound & cLogP & $\log S$ & $\mathbf{M}$ & TPSA & n-OHNH & $\mathrm{n}-\mathrm{ON}$ & $\begin{array}{l}\text { Conformity to } \\
\text { Lipinsky's } \\
\text { Rule of Five }\end{array}$ \\
\hline 1 & 2.51 & -3.35 & 211 & 34.1 & 0 & 2 & + \\
\hline 2 & 0.68 & -3.77 & 326 & 62.4 & 0 & 2 & + \\
\hline 3 & -0.16 & -2.90 & 321 & 47.0 & 0 & 3 & + \\
\hline 4 & 0.73 & -3.65 & 320 & 34.1 & 0 & 2 & + \\
\hline 5 & 0.73 & -3.65 & 320 & 34.1 & 0 & 2 & + \\
\hline 6 & 0.02 & -2.41 & 242 & 60.1 & 2 & 3 & + \\
\hline 7 & 1.45 & -3.20 & 292 & 34.1 & 0 & 3 & + \\
\hline 8 & 2.36 & -3.80 & 319 & 43.4 & 0 & 3 & + \\
\hline 9 & 1.7 & -3.52 & 276 & 34.1 & 0 & 2 & + \\
\hline 10 & 2.94 & -4.13 & 318 & 34.1 & 0 & 2 & + \\
\hline 11 & 2.19 & -3.43 & 343 & 52.6 & 0 & 4 & + \\
\hline doxorubicin & 0.17 & -1.23 & 543 & 206.0 & 7 & 12 & - \\
\hline gemcitabin & -2.04 & -2.04 & 263 & 108.3 & 4 & 7 & + \\
\hline irinotecan & 3.56 & -4.50 & 586 & 112.5 & 2 & 7 & - \\
\hline methotrexate & -1.23 & -3.77 & 454 & 210.5 & 7 & 13 & + \\
\hline 5-fluorouracil & -0.59 & -1.07 & 130 & 65.72 & 2 & 4 & + \\
\hline
\end{tabular}

cLogP: base 10 logarithm of the octanol/water partition coefficient; logS: base 10 logarithm of water solubility; M: molecular weight; TPSA: topological polar surface area; n-OHNH: number of hydrogen bond-donors; $n-O N$ : number of hydrogen bond acceptors; +: conformity with RO5; -: violation of RO5

According to the results of the predictive in silico assay the organoselenium compounds are expected to have excellent oral bioavailability (96.74-99.10\%) and based on the predicted permeability on Caco-2 monolayers it can be concluded that the compounds have moderate penetration properties. The predicted plasma protein binding (PPB\%) is nearly $100 \%$ for all respective selenocompounds, which can be attributed to the presence of the selenium atom in the biologically active molecules (Table 9.). The newly developed selenium compounds should be inhibitors of the CYP2C9 enzyme and excluding compound 6, they are presumably substrates and inhibitors of the CYP3A4 enzyme, which may pose an issue, if these compounds were to be co-administered with anticancer drugs that are metabolized by these enzymes. The molecules are not expected to interact with the CYP2D6 enzyme. 
Table 9. Predicted pharmacokinetic properties of the tested selenocompounds and reference chemotherapeutic agents

\begin{tabular}{ccccc}
\hline Compound & $\begin{array}{c}\text { PPB } \\
{[\%]}\end{array}$ & $\begin{array}{c}\text { Permeability on Caco-2 } \\
\text { monolayer [nm/s] }\end{array}$ & $\begin{array}{c}\text { Permeability on MDCK } \\
\text { monolayer [nm/s] }\end{array}$ & $\begin{array}{c}\text { HIA } \\
{[\%]}\end{array}$ \\
\hline $\mathbf{1}$ & $\sim 100$ & 11.83 & 0.35 & 99.33 \\
$\mathbf{2}$ & $\sim 100$ & 34.66 & 0.33 & 98.55 \\
$\mathbf{3}$ & $\sim 100$ & 24.29 & 0.51 & 98.10 \\
$\mathbf{4}$ & $\sim 100$ & 30.22 & 0.33 & 99.10 \\
$\mathbf{5}$ & $\sim 100$ & 22.86 & 0.33 & 99.10 \\
$\mathbf{6}$ & $\sim 100$ & 10.46 & 0.43 & 96.74 \\
$\mathbf{7}$ & $\sim 100$ & 47.51 & 0.26 & 97.96 \\
$\mathbf{8}$ & $\sim 100$ & 53.01 & 0.14 & 97.66 \\
$\mathbf{9}$ & $\sim 100$ & 46.01 & 0.27 & 99.09 \\
$\mathbf{1 0}$ & $\sim 100$ & 54.52 & 0.08 & 99.01 \\
$\mathbf{1 1}$ & $\sim 100$ & 54.32 & 0.15 & 98.18 \\
doxorubicin & 31.16 & 17.73 & 1.02 & 56.84 \\
gemcitabin & 14.94 & 6.90 & 0.59 & 79.19 \\
irinotecan & 57.56 & 28.17 & 0.05 & 96.87 \\
methotrexate & 57.42 & 18.93 & 0.34 & 86.16 \\
5-fluorouracil & 9.9 & 17.25 & 0.17 & 75.93 \\
\hline
\end{tabular}

PPB: plasma protein binding; MDCK: Madin-Darby canine kidney; HIA: human intestinal absorption

Based on the results of the correlation-regression analysis, the calculated base 10 logarithm of fluorescence activity ratios ( $\log F A R$; which correlates with efflux pump modulatory activity) for the tested selenocompounds showed significant association with their base 10 logarithm of the octanol/water partition coefficients $(c \log P)$, both in the case of the measured data (see Section VI.B., page 32.) on MDR mouse T-lymphoma $\left(\mathrm{p}=0.0034 ; \mathrm{R}^{2}=0.6934\right)$ and Colo 320 colonic adenocarcinoma cells $\left(p=0.0198 ; \mathrm{R}^{2}=0.5117\right)$ (Figure 14.) The molecular weight $\left(\mathrm{p}>0.05 ; \mathrm{R}^{2}=0.027-0.1247\right)$, the base 10 logarithm of topological polar surface area $(\mathrm{p}>0.05$; $\left.\mathrm{R}^{2}=0.081-0.237\right)$ and the base 10 logarithm of water solubility $\left(\mathrm{p}>0.05 ; \mathrm{R}^{2}=0.024-0.1229\right) \mathrm{did}$ not show relevant correlation with the fluorescence $(\log F A R)$ data.
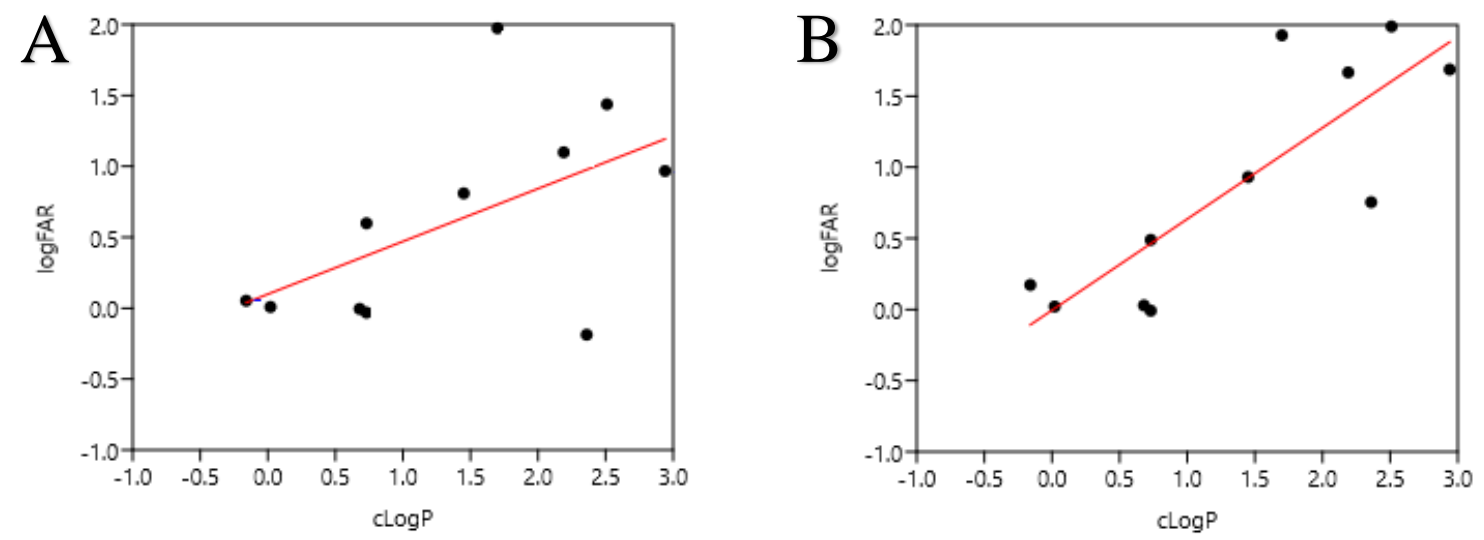

Figure 14. Correlation of predicted cLogP values of the tested compounds with calculated fluorescence activity ratio (FAR) values

A: MDR mouse T-lymphoma cells; B: Colo 320 colon adenocarcinoma cells $\log _{\text {FARlymphoma: }}: \operatorname{LogP} P_{\text {Se: }} y=0,6413 x-0,005 ; p=0.0034 ; R_{2}=0.6934(69.34 \%)$ $\log _{\text {FARColo320:cLogPse }} \mathbf{y}=0,3576 x-0,325 ; p=0,0198 ; R^{2}=0.5117(51.17 \%)$ 


\section{DISCUSSION}

Malignant diseases present a significant public health burden, accounting for 8.2 million deaths and 14.1 million new cancer cases worldwide (according to the data of the WHO). Due to the phenomenon of ageing population in developed countries, the mortality rates related to cancer are expected to increase further. Hungary has the worst mortality rates of lung and colon cancer among EU member states. The goal of chemotherapy (the most commonly used treatment modality) is the elimination or reduction of malignant cell mass and to improve the quality of life of the patient. The use of chemotherapy is complicated by its low bioavailability, disadvantageous side effects due to non-selective cytotoxic activity, in addition to the emergence of multidrug resistance, whereby tumors show resistance to chemotherapeutic agents of different structure and mechanism of action. The two mechanisms of MDR elucidated in this thesis are the overexpression of energy-dependent efflux pumps and failure of apoptosis induction. Considerable number of compounds have been described with the ability to inhibit the function of the ABCB1 efflux pump, an emerging therapeutic strategy of using chemosensitizers as adjuvants reversing the MDR phenotype. Inorganic selenium salts and organoselenium compounds have been extensively studied for their anticancer activities. Organic compounds containing selenium are known modulators of the intracellular redox state of mammalian cells, therefore they may be effective and selective anticancer drugs, since neoplastic cells are thought to be sensitive to exogenous ROS. The aim of this study was to assess the activity of novel organoselenium compounds as anticancer agents and their potency as MDR reversers with respect to the epidemiology of cancer in Hungary. An additional aim was to establish structure-activity relationship for the selenocompounds and to predict their attributes as lead compounds for further studies.

Considering our results, we can conclude that selenocompounds with specific structures (Figure 15.) showed potent activity in all assays, while others presented with limited or no activity whatsoever. The compounds that were chosen as references (12-15) had no activity in any of the experiments. In the cytotoxicity assays, the chemical variation of the alkyl chain directly bound to the selenium atom in the selenoesters was key in modulating anticancer efficacy. A methyl (9) or tert-butylketone-substituent $(\mathbf{1 0 , 1 1 )}$ was the most profitable for cytotoxic activity, in addition to the cyclic selenoanhydride (1). Conversely, if these conditions are not met, or the alkyl ketone group was replaced by an amide, ester or unsubstituted methyl group, then the compounds showed little or no cytotoxic activity. The substituents on the aromatic ring seem to be less important for determining their anticancer potency. In general, the selenocompounds were the least effective and selective on the A549 lung adenocarcinoma cells. The potency of the selenoesters 9-11 is further verified by the fact that they had $\mathrm{IC}_{50}$ values in the nanomolar range in many cases and showed SI values over 6 , in respect to human adenocarcinoma cells. The selenoanhydride presented with very high selectivity in murine cell lines (>20) and was not toxic on any of the non-tumoral cell lines. An interesting pattern of selectivity was found in the cases of compounds $\mathbf{1}, \mathbf{4}$, and $\mathbf{8}$ because they had a preference for the MDR subline of the colon adenocarcinoma cells. 
Results obtained from the rhodamine 123 accumulation studies are in concordance with those from the cytotoxicity assay. The 4-chlorophenyl-substituted methyl-ketonesubstituted selenoester (9) was the most active compound (surpassing any other tested molecule in $2 \mu \mathrm{M}$ concentration), followed by cyclic selenoanhydride and the two remaining acylmethyl-selenoesters $(\mathbf{1 0}, \mathbf{1 1})$, showing similarly potent ABCB1 inhibition at $20 \mu \mathrm{M}$. The efflux pump modulatory activity of selenoesters 2-8 was not comparable to the activity of verapamil, due to the variable side chains in their structures. It is also important to note that the lipophilicity of the compounds influenced ABCB1 modulation, as the cLogP values showed significant $(\mathrm{p}<0.05)$ correlation with the calculated FAR values. In the apoptosis assay, the abovementioned four compounds induced apoptosis in 39.01-97.32\% of the tested murine cells and 64.6-71.4\% of human cells, respectively. However, the selenoanhydride (1) was the most effective inducer of early apoptosis (around one-third of the gated cell population of mouse T-lymphoma cells and two-thirds of the colonic adenocarcinoma cells), surpassing the activity of the positive control (M627) used in the experiments. On the other hand, the acylmethyl-selenoesters also had pronounced toxic activity, which predominantly presented as necrosis (up to $85.80 \%$ in murine cells). This distinction in the activity profiles is relevant because early apoptosis is the advantageous type of cell death for chemotherapytreated malignant cells, as collateral damage will not occur in adjacent cells due to the release of inflammatory mediators compared to necrotic cell death processes $[100,188]$. The remaining selenoesters (2-8) had slight or no capacity to induce apoptosis, although the human colonic adenocarcinoma cell line showed to be more sensitive to the treatment with the selenocompounds.<smiles>O=C1[Se]C(=O)c2ccccc21</smiles>

9<smiles>CC(=O)C[Se]C(=O)c1ccc(Cl)cc1</smiles><smiles>CC(C)(C)C(=O)C[Se]C(=O)c1ccc(Cl)cc1</smiles>

11<smiles>COc1cc(OC)cc(C(=O)[Se]CC(=O)C(C)(C)C)c1</smiles>

Figure 15. Selenocompounds identified as promising candidates for further studies

1: Benzo[c]selenophen-1,3-dione; 9: Methoxycarbonylmethyl 4-chlorobenzoselenoate; 10: 3,3-Dimethyl-2oxobutyl 4-chlorobenzoselenoate; 11: 3,3-Dimethyl-2-oxobutyl 3,5-dimethoxybenzoselenoate 
Organic compounds containing chalcogenic elements $(\mathrm{S}, \mathrm{Se}, \mathrm{Te})$ recently received substantial interest in experimental oncopharmacology [128]. The literature suggests that the most active member of this group is tellurium (Te); but it has been shown that the Tecontaining compounds are highly toxic and do not possess adequate selectivity $[129,137]$. The advantage of Se compounds is that they influence various cellular redox mechanisms and signal transduction pathways, which makes them especially appealing for researchers. The reference compound 12, which showed no activity in any of the experiments, is the oxygen-isoster of the cyclic selenoanhydride, which suggests the significant role of Se atom for the activity of these organic molecules [189]. In addition, the structurally similar sulfur analogues of these compounds were synthesized by Domínguez-Álvarez et al., and the biological characterization of these compounds was performed in our laboratory. Based on these results, the role of Se for anticancer and MDR-reversing activity was further highlighted [190-193], as the $\mathrm{Se} \rightarrow \mathrm{S}$ switch in these molecules resulted in diminished biological activity (unpublished data).

The exact molecular mechanism of these compounds is yet to be described [135]. According to the previous studies and hypotheses of Domínguez-Álvarez et al., it is proposed that the activity of organoselenium derivatives lies in the hydrolysis of the selenoester group. This breakdown allows the liberation of selenium anions to the medium, allowing for these particles to take part in oxidation-reduction reactions due to the charged selenium atom. In other words, it is suggested that the novel selenoesters act as prodrugs that make the transport of the molecules possible through the cell cytoplasm. Inside the cells, the breakdown of the carrier molecule liberates the active ionic chemical forms of selenium with cytotoxic properties in cells. The inclusion of electron withdrawing groups, like a ketone or a carboxylic acid is thought to facilitate the breakdown for stabilizing the resulting fragments. However, it is not desirable to design derivatives whose breakdown occurs before the arrival of the compound to the cytoplasm of target cells. In this case, the ionic species generated in the extracellular hydrolysis would not pass the cell membrane due to their hydrophilic properties, which may explain the low activity of selenoesters $\mathbf{2 - 8}$.

The rationale behind the activity of the cyclic selenoanhydride (1) is presumably like those of compounds 9-11, however, the degradation mechanisms and kinetics of this compound should be different, as it contains the Se atom in a five-member ring system. Also, it is not clear whether the tested compounds are competitive inhibitors of the efflux pump or bind to a specific domain of the ABCB1 transporter, which is essential to the pumping function of the protein. The use of experimental methods or molecular docking studies is required to further elucidate the exact mechanisms of activity. 
Overall, four compounds were identified as promising candidates for further studies: the cyclic selenoanhydride (1; benzo[c]selenophene-1,3-dione), in addition to the selenoesters 9-11 (Figure 15.). All respective compounds exhibited remarkable anticancer and multidrug resistance reversing (ABCB1 pump-modulating and apoptosis inducing) properties. Considering the predicted data from the in silico assays, these four compounds show attractive properties for good in vivo bioavailability and potential for transitioning from the pre-clinical to clinical study phase (as presented by their conformity to the RO5 and predicted HIA percentages). As for future perspectives, the derivatization and synthesis of novel structural variants of these compounds are warranted. In addition, as there is abundant literature regarding various selenium compounds co-administered with various chemotherapeutic drugs, the survey of these agents in vitro could shed some light about their potency as combinational drugs. 


\section{NEW FINDINGS}

a. Selenocompounds as cytotoxic agents: Three selenoesters with ketone-containing alkyl groups showed potent cytotoxic activity on mouse T-lymphoma, human colon adenocarcinoma and human lung adenocarcinoma cell lines with $\mathrm{IC}_{50}$ values in the nanomolar range. The cyclic selenoanhydride was highly active and selective towards malignant murine cell lines.

b. Selenocompounds as efflux pump inhibitors: The cyclic selenoanhydride and three selenoesters with ketone-containing alkyl groups showed potent efflux pump modulatory effects in the ABCB1-overexpressing subline of mouse T-lymphoma and human colon adenocarcinoma cell lines. The 4-chlorophenyl-substitution was the most beneficial for ABCB1-inhibiting activity on both murine and human cell lines.

c. Selenocompounds as apoptosis inducers: The cyclic selenoanhydride was an effective inducer of early apoptosis, while the selenoesters with ketone-containing alkyl groups predominantly induced late apoptosis/necrosis in parental and multidrug resistant mouse Tlymphoma and MDR human colon adenocarcinoma cell lines.

d. Prediction of ADME properties of the selenocompounds by in silico methods: All organoselenium compounds compiled with Lipinsky's Rule of Five and they are expected to have moderate intestinal penetration properties, very strong plasma protein binding and excellent oral bioavailability. The results suggest a link between the lipophilicity and efflux pump modulatory activity of the compounds. 


\section{SUMMARY}

Cancer-related mortality is the second major cause of death with 8.2 million deaths and 14.1 million new cancer cases across the globe in 2012. Among the EU member states, the incidence of lung and colon cancers and the mortality associated with these tumors is highest in Hungary. The goal of chemotherapy (the most commonly used treatment modality) is the elimination or reduction of malignant cell mass and to improve the quality of life of the patient. The use of chemotherapy is complicated by its low bioavailability, disadvantageous side effects due to non-selective cytotoxic activity and the emergence of multidrug resistance, whereby tumors show resistance to chemotherapeutic agents of different structure and mechanism of action. The two main mechanisms of MDR investigated by our study are the failure of apoptosis induction and overexpression of energy-dependent efflux pumps. Considerable number of compounds have been described with the ability to inhibit the function of the ABCB1 efflux pump. An emerging therapeutic strategy is the use of chemosensitizers as adjuvants, reversing the MDR phenotype associated with these cancer cells. Inorganic selenium salts and organoselenium compounds have been extensively studied for their anticancer activities. Organic compounds containing selenium are known modulators of the intracellular redox state of mammalian cells, they may be effective and selective anticancer drugs, because neoplastic cells are thought to be sensitive to exogenous ROS. The aim of this thesis was to assess the activity of novel organoselenium compounds synthesized by Domínguez-Álvarez et al. as anticancer agents and their potency as MDR reversers on various cancer model systems in vitro. The cytotoxic activity of the compounds was assessed by MTT method, the inhibition of the MDR transporter ABCB1 was studied by rhodamine 123 accumulation assay using flow cytometry. The apoptosis inducing properties of the compounds were determined by Annexin V-FITC detection method, using flow cytometry. A preliminary in silico assay was performed using OSIRIS Molecular Property Explorer and PreADMET 2.0 to predict the physicochemical and in vivo absorption properties of the selenocompounds. We can conclude that selenocompounds with specific structures (four compounds; a cyclic selenoanhydride and three selenoesters with ketone-containing alkyl groups) showed potent activity in all assays, while others presented with limited or no activity. The abovementioned compounds exhibited potent cytotoxic activities, with effective concentrations in the nanomolar range, they were potent inhibitors of the ABCB1 efflux protein. Results suggest the lipophilicity of the compounds has an important role in their efflux pump modulatory activity. The cyclic selenoanhydride was a potent inducer of early apoptosis, while the alkyl-ketone-containing selenoesters induced necrotic processes. According to the predicted in silico data, organoselenium compounds are expected to have moderate intestinal penetration and excellent oral bioavailability. Our experiments highlighted the role of selenium for anticancer and MDR-reversing activity. The exact molecular mechanism of these compounds is yet to be described: it is proposed that the activity of organoselenium derivatives lies in the hydrolysis of the selenoester group. Based on our results, the derivatization and synthesis of novel structural variants of these compounds is warranted. 


\section{X. ÖSSZEFOGLALÓ}

A daganatos megbetegedések a második vezető haláloknak számítanak, 2012-ben világszerte 8,2 millió rákhoz köthető halálesetet és 14,1 millió új rákos beteget regisztráltak. Az EU tagállamai közül a tüdö- és vastagbélrák előfordulási gyakorisága és az ezekhez a daganatokhoz kapcsolódó halálozás Magyarországon a legmagasabb. A kemoterápia célja (amely a leggyakrabban alkalmazott kezelési mód) a rosszindulatú sejttömeg elpusztítása vagy a méretének csökkentése, ezzel egyidőben a beteg életminőségének javítása. A kemoterápia alkalmazását megnehezíti a szerek alacsony biohasznosíthatósága, a nem szelektív citotoxikus hatás és a multidrog rezisztens (MDR) fenotípus kialakulása, melynek során a daganatsejtek több, különböző hatásmechanizmusú és kémiai szerkezetű szerrel szemben mutatnak rezisztenciát. Az MDR két, általunk is vizsgált fö mechanizmusa az energiafüggő efflux pumpák túltermelődése és az apoptózis indukciójának gátlása. Számos vegyületet leírtak már, mely képes gátolni az ABCB1 efflux pumpa müködését. Ígéretes terápiás stratégiának tekintik az MDR-visszafordító vegyületek alkalmazását adjuvánsként, ismét érzékennyé téve a daganatos sejteket a kemoterápiára. A szervetlen és szerves szelénvegyületeket széleskörüen tanulmányozták daganatellenes hatásuk szempontjából. A szerves szelénvegyületekről köztudott, hogy képesek modulálni az emlőssejtek intracelluláris redox homeosztázisát, így hatékony és szelektív daganatellenes szerek lehetnek, mivel a daganatos sejtek érzékenyebbek a külső ROS hatásokra. A jelen disszertáció célja Domínguez-Álvarez és mtsai. által szintetizált, újszerü szerkezettel rendelkező szerves szelénvegyületek daganatellenes és MDRvisszafordító hatásának vizsgálata különböző daganatsejtes modellrendszerek felhasználásával in vitro. A vegyületek citotoxikus aktivitását MTT módszerrel határoztuk meg, az ABCB1 efflux transzporter gátlását rhodamin 123 akkumulációs vizsgálattal tanulmányoztuk áramlási citometriás módszerrel. A vegyületek apoptózist indukáló hatását Annexin V-FITC módszerrel határoztuk meg áramlási citometriával. OSIRIS Molecular Property Explorer és PreADMET 2.0 alkalmazásával becsültük meg a vegyületek fizikai-kémiai és in vivo abszorpciós tulajdonságait. Megállapítható, hogy az adott szerkezeti elemekkel (négy vegyület: egy ciklusos szelenoanhidrid és három alkil-keton-szelenoészter) rendelkező szelénvegyületek hatékonynak bizonyultak minden vizsgálatban, míg mások csökkent vagy semmilyen aktivitást nem mutattak. A fent említett vegyületek erős citotoxikus hatásúak voltak a nanomoláris tartományban, emellett hatékonyan gátolták az ABCB1 efflux pumpát. Az eredmények arra engednek következtetni, hogy a vegyületek lipofilitásának fontos szerepe van az efflux pumpa müködésének befolyásolásában. A ciklikus szelenoanhidrid hatékony korai apoptózist indukáló vegyület volt, míg az alkil-keton szelenoészterek nekrotikus folyamatokat indukáltak. Az in silico eredmények alapján a szerves szelénvegyületek várhatóan mérsékelt bélpenetrációval és kiváló orális biológiai hasznosíthatósággal rendelkeznek. Kísérleteink rávilágíttotak a szelén központi szerepére a rákellenes és az MDR-visszafordító hatás szempontjából. A vegyületek pontos molekuláris hatásmechanizmusa még nem ismert: azt feltételezhetjük, hogy a szelénvegyületek aktivitása a szelenoészter csoport hidrolíziséhez köthető. Eredményeink alapján az ígéretes vegyületek további származékainak szintézise és biológiai hatásának vizsgálata indokolt lehet. 


\section{REFERENCES}

1. CDC - Cancer Data and Statistics Available online: https://www.cdc.gov/cancer/dcpc/data/index.htm (accessed on Jul 8, 2018).

2. Ferlay, J.; Soerjomataram, I.; Dikshit, R.; Eser, S.; Mathers, C.; Rebelo, M.; Parkin, D.M.; Forman, D.; Bray, F. Cancer incidence and mortality worldwide: sources, methods and major patterns in GLOBOCAN 2012. Int. J. Cancer 2015, 136, E359-386, doi:10.1002/ijc.29210.

3. Jemal, A.; Bray, F.; Center, M.M.; Ferlay, J.; Ward, E.; Forman, D. Global cancer statistics. CA. Cancer J. Clin. 2011, 61, 69-90, doi:10.3322/caac.20107.

4. Siegel, R.; Naishadham, D.; Jemal, A. Cancer statistics, 2013. CA. Cancer J. Clin. 2013, 63, 11-30, doi:10.3322/caac.21166.

5. Siegel, R.; DeSantis, C.; Virgo, K.; Stein, K.; Mariotto, A.; Smith, T.; Cooper, D.; Gansler, T.; Lerro, C.; Fedewa, S.; et al. Cancer treatment and survivorship statistics, 2012. CA. Cancer J. Clin. 2012, 62, 220-241, doi:10.3322/caac.21149.

6. WHO | World Cancer Report 2014 Available online: http://www.who.int/cancer/publications/WRC_2014/en/ (accessed on Jul 27, 2018).

7. Globocan 2012 - Home Available online: http://globocan.iarc.fr/Default.aspx (accessed on Jul 8, 2018).

8. National cancer control programmes: policies and managerial guidelines; World Health Organization, Ed.; 2nd ed.; World Health Organization: Geneva, 2002; ISBN 978-92-4154557-0.

9. Kozovska, Z.; Gabrisova, V.; Kucerova, L. Colon cancer: cancer stem cells markers, drug resistance and treatment. Biomed. Pharmacother. 2014, 68, 911-916, doi:10.1016/j.biopha.2014.10.019.

10. Zappa, C.; Mousa, S.A. Non-small cell lung cancer: current treatment and future advances. Transl. Lung Cancer Res. 2016, 5, 288-300, doi:10.21037/tlcr.2016.06.07.

11. La Vecchia, C.; Conte, P. Cancer Control in Central and Eastern Europe. The Oncologist 2016, 21, 1161-1162, doi:10.1634/theoncologist.2016-0230.

12. Primic-Zakelj, M.; Zadnik, V.; Zagar, T. Is cancer epidemiology different in Western Europe to that in Eastern Europe? J. Eur. Soc. Med. Oncol. 2005, 16 Suppl 2, ii27-29, doi:10.1093/annonc/mdi725.

13. A haláloki struktúra változása Magyarországon, 2000-2012. 1-45. Központi Statisztikai Hivatal (KSH) 2014, Available online: https://www.ksh.hu/docs/hun/xftp/idoszaki/pdf/halalokistruk.pdf (accessed on Nov 15, 2018).

14. Szabolcs, O. Cancer epidemiology in Hungary and the Béla Johan National Program for the decade of health. Pathol. Oncol. Res. 2003, 9, 126-130, doi:PAOR.2003.9.2.0126.

15. Rákregiszter statisztika | Országos Onkológiai Intézet Available online: http://www.onkol.hu/hu/rakregiszter-statisztika (accessed on Jul 27, 2018).

16. Tamás M.; Katalin M.B. Demográfiai jellemzõk Magyarországon és az Európai Unióban, különös tekintettel a daganatos megbetegedések okozta halálozásra. Statisztikai Szle. 2012, 90, 1-15.

17. Munro, A.J. Comparative cancer survival in European countries. Br. Med. Bull. 2014, 110, 5-22, doi:10.1093/bmb/ldu009.

18. Gale Encyclopedia of Cancer: A Guide to Cancer and its Treatments (3rd edition). Ref. Rev. 2011, 25, 40-41, doi:10.1108/09504121111168677.

19. Hanahan, D.; Weinberg, R.A. Hallmarks of cancer: the next generation. Cell 2011, 144, 646-674, doi:10.1016/j.cell.2011.02.013. 
20. Schiffer, C.A.; Stone, R.M. Morphologic Classification and Clinical and Laboratory Correlates. Holland-Frei Cancer Medicine. 6th edition. 2003.

21. Lam, V.K.; Nguyen, T.C.; Chung, B.M.; Nehmetallah, G.; Raub, C.B. Quantitative assessment of cancer cell morphology and motility using telecentric digital holographic microscopy and machine learning. Cytom. 2018, 93, 334-345, doi:10.1002/cyto.a.23316.

22. Ziperstein, M.J.; Guzman, A.; Kaufman, L.J. Evaluating Breast Cancer Cell Morphology as a Predictor of Invasive Capacity. Biophys. J. 2016, 110, 621a, doi:10.1016/j.bpj.2015.11.3333.

23. Petrucelli, N.; Daly, M.B.; Pal, T. BRCA1- and BRCA2-Associated Hereditary Breast and Ovarian Cancer. In GeneReviews ${ }^{\circledR}$; Adam, M.P., Ardinger, H.H., Pagon, R.A., Wallace, S.E., Bean, L.J., Stephens, K., Amemiya, A., Eds.; University of Washington, Seattle: Seattle (WA), 1993.

24. Parsa, N. Environmental Factors Inducing Human Cancers. Iran. J. Public Health 2012, $41,1-9$.

25. Avanzi, S.; Alvisi, G.; Ripalti, A. How virus persistence can initiate the tumorigenesis process. World J. Virol. 2013, 2, 102-109, doi:10.5501/wjv.v2.i2.102.

26. Chen, C.-J.; Hsu, W.-L.; Yang, H.-I.; Lee, M.-H.; Chen, H.-C.; Chien, Y.-C.; You, S.-L. Epidemiology of virus infection and human cancer. Recent Results Cancer Res. 2014, 193, 11-32, doi:10.1007/978-3-642-38965-8_2.

27. Morales-Sánchez, A.; Fuentes-Pananá, E.M. Human Viruses and Cancer. Viruses 2014, 6, 4047-4079, doi:10.3390/v6104047.

28. Mostafa, M.H.; Sheweita, S.A.; O’Connor, P.J. Relationship between Schistosomiasis and Bladder Cancer. Clin. Microbiol. Rev. 1999, 12, 97-111.

29. Ahn, H.J.; Lee, D.S. Helicobacter pylori in gastric carcinogenesis. World J. Gastrointest. Oncol. 2015, 7, 455-465, doi:10.4251/wjgo.v7.i12.455.

30. The Genetics of Cancer Available online: https://www.cancer.net/navigating-cancercare/cancer-basics/genetics/genetics-cancer (accessed on Jul 29, 2018).

31. Loeb, K.R.; Loeb, L.A. Significance of multiple mutations in cancer. Carcinogenesis 2000 , 21, 379-385, doi:10.1093/carcin/21.3.379.

32. Martincorena, I.; Campbell, P.J. Somatic mutation in cancer and normal cells. Science 2015, 349, 1483-1489, doi:10.1126/science.aab4082.

33. Darzynkiewicz, Z.; Bruno, S.; Del Bino, G.; Gorczyca, W.; Hotz, M.A.; Lassota, P.; Traganos, F. Features of apoptotic cells measured by flow cytometry. Cytometry 1992, 13, 795-808, doi:10.1002/cyto.990130802.

34. Chabner, B.A.; Jr, T.G.R. Chemotherapy and the war on cancer. Nat. Rev. Cancer 2005, 5, 65-72, doi:10.1038/nrc1529.

35. Jaffray, D.A.; Gospodarowicz, M.K. Radiation Therapy for Cancer. In Cancer: Disease Control Priorities, Third Edition (Volume 3); Gelband, H., Jha, P., Sankaranarayanan, R., Horton, S., Eds.; The International Bank for Reconstruction and Development / The World Bank: Washington (DC), 2015 ISBN 978-1-4648-0349-9.

36. Mullen, M.G.; Shah, P.M.; Michaels, A.D.; Hassinger, T.E.; Turrentine, F.E.; Hedrick, T.L.; Friel, C.M. Neoadjuvant Chemotherapy Is Associated with Lower Lymph Node Counts in Colon Cancer. Am. Surg. 2018, 84, 996-1002.

37. Beaver, C.C.; Magnan, M.A. Managing Chemotherapy Side Effects: Achieving Reliable and Equitable Outcomes. Clin. J. Oncol. Nurs. 2016, 20, 589-591, doi:10.1188/16.CJON.589-591.

38. Galizia, D.; Milani, A.; Geuna, E.; Martinello, R.; Cagnazzo, C.; Foresto, M.; Longo, V.; Berchialla, P.; Solinas, G.; Calori, A.; et al. Self-evaluation of duration of adjuvant chemotherapy side effects in breast cancer patients: A prospective study. Cancer Med. 2018, doi:10.1002/cam4.1687. 
39. Di Maio, M.; Gallo, C.; Leighl, N.B.; Piccirillo, M.C.; Daniele, G.; Nuzzo, F.; Gridelli, C.; Gebbia, V.; Ciardiello, F.; De Placido, S.; et al. Symptomatic toxicities experienced during anticancer treatment: agreement between patient and physician reporting in three randomized trials. J. Clin. Oncol. 2015, 33, 910-915, doi:10.1200/JCO.2014.57.9334.

40. Godugu, C.; Patel, A.R.; Doddapaneni, R.; Somagoni, J.; Singh, M. Approaches to Improve the Oral Bioavailability and Effects of Novel Anticancer Drugs Berberine and Betulinic Acid. Plos One 2014, 9, e89919, doi:10.1371/journal.pone.0089919.

41. Stuurman, F.E.; Nuijen, B.; Beijnen, J.H.; Schellens, J.H.M. Oral anticancer drugs: mechanisms of low bioavailability and strategies for improvement. Clin. Pharmacokinet. 2013, 52, 399-414, doi:10.1007/s40262-013-0040-2.

42. Wilson, M.K.; Karakasis, K.; Oza, A.M. Outcomes and endpoints in trials of cancer treatment: the past, present, and future. Lancet Oncol. 2015, 16, e32-e42, doi:10.1016/S1470-2045(14)70375-4.

43. Bodey, B.; Siegel, S.E.; Kaiser, H.E. Human cancer detection and immunotherapy with conjugated and non-conjugated monoclonal antibodies. Anticancer Res. 1996, 16, 661-674.

44. Scott, A.M.; Allison, J.P.; Wolchok, J.D. Monoclonal antibodies in cancer therapy. Cancer Immun. 2012, 12.

45. Hartmann, J.T.; Haap, M.; Kopp, H.-G.; Lipp, H.-P. Tyrosine kinase inhibitors - a review on pharmacology, metabolism and side effects. Curr. Drug Metab. 2009, 10, 470-481.

46. Orphanos, G.S.; Ioannidis, G.N.; Ardavanis, A.G. Cardiotoxicity induced by tyrosine kinase inhibitors. Acta Oncol. 2009, 48, 964-970, doi:10.1080/02841860903229124.

47. Rossig, C. CAR T cell immunotherapy in hematology and beyond. Clin. Immunol. 2018, 186, 54-58, doi:10.1016/j.clim.2017.09.016.

48. Hermine, O.; Ramos, J.C.; Tobinai, K. A Review of New Findings in Adult T-cell Leukemia-Lymphoma: A Focus on Current and Emerging Treatment Strategies. Adv. Ther. 2018, 35, 135-152, doi:10.1007/s 12325-018-0658-4.

49. Newick, K.; O’Brien, S.; Moon, E.; Albelda, S.M. CAR T Cell Therapy for Solid Tumors. Annu. Rev. Med. 2017, 68, 139-152, doi:10.1146/annurev-med-062315-120245.

50. Zhao, Z.; Chen, Y.; Francisco, N.M.; Zhang, Y.; Wu, M. The application of CAR-T cell therapy in hematological malignancies: advantages and challenges. Acta Pharm. Sin. B 2018, 8, 539-551, doi:10.1016/j.apsb.2018.03.001.

51. Caldemeyer, L.; Dugan, M.; Edwards, J.; Akard, L. Long-Term Side Effects of Tyrosine Kinase Inhibitors in Chronic Myeloid Leukemia. Curr. Hematol. Malig. Rep. 2016, 11, $71-$ 79, doi:10.1007/s11899-016-0309-2.

52. Hansel, T.T.; Kropshofer, H.; Singer, T.; Mitchell, J.A.; George, A.J.T. The safety and side effects of monoclonal antibodies. Nat. Rev. Drug Discov. 2010, 9, 325-338, doi: $10.1038 / \mathrm{nrd} 3003$.

53. Moureau-Zabotto, L.; Ricci, S.; Lefranc, J.P.; Coulet, F.; Genestie, C.; Antoine, M.; Uzan, S.; Lotz, J.P.; Touboul, E.; Lacave, R. Prognostic impact of multidrug resistance gene expression on the management of breast cancer in the context of adjuvant therapy based on a series of 171 patients. Br. J. Cancer 2006, 94, 473-480, doi:10.1038/sj.bjc.6602958.

54. Alfarouk, K.O.; Stock, C.-M.; Taylor, S.; Walsh, M.; Muddathir, A.K.; Verduzco, D.; Bashir, A.H.H.; Mohammed, O.Y.; Elhassan, G.O.; Harguindey, S.; et al. Resistance to cancer chemotherapy: failure in drug response from ADME to P-gp. Cancer Cell Int. 2015, 15, 71, doi:10.1186/s12935-015-0221-1.

55. Dano, K. Cross resistance between vinca alkaloids and anthracyclines in Ehrlich ascites tumor in vivo. Cancer Chemother. Rep. 1972, 56, 701-708.

56. Ughachukwu, P.; Unekwe, P. Efflux Pump-Mediated Resistance in Chemotherapy. Ann. Med. Health Sci. Res. 2012, 2, 191-198, doi:10.4103/2141-9248.105671. 
57. Housman, G.; Byler, S.; Heerboth, S.; Lapinska, K.; Longacre, M.; Snyder, N.; Sarkar, S. Drug resistance in cancer: an overview. Cancers 2014, 6, 1769-1792, doi:10.3390/cancers6031769.

58. Chuman, Y.; Sumizawa, T.; Takebayashi, Y.; Niwa, K.; Yamada, K.; Haraguchi, M.; Furukawa, T.; Akiyama, S.; Aikou, T. Expression of the multidrug-resistance-associated protein (MRP) gene in human colorectal, gastric and non-small-cell lung carcinomas. Int. J. Cancer 1996, 66, 274-279, doi:10.1002/(SICI)1097-0215(19960410)66.

59. Gillet, J.-P.; Gottesman, M.M. Mechanisms of multidrug resistance in cancer. Methods Mol. Biol. 2010, 596, 47-76, doi:10.1007/978-1-60761-416-6_4.

60. Masuda, H.; Ozols, R.F.; Lai, G.M.; Fojo, A.; Rothenberg, M.; Hamilton, T.C. Increased DNA repair as a mechanism of acquired resistance to cis-diamminedichloroplatinum (II) in human ovarian cancer cell lines. Cancer Res. 1988, 48, 5713-5716.

61. Baguley, B.C. Multidrug resistance in cancer. Methods Mol. Biol. 2010, 596, 1-14, doi:10.1007/978-1-60761-416-6_1.

62. Amaral, L.; Spengler, G.; Molnar, J. Identification of Important Compounds Isolated from Natural Sources that Have Activity Against Multidrug-resistant Cancer Cell Lines: Effects on Proliferation, Apoptotic Mechanism and the Efflux Pump Responsible for Multiresistance Phenotype. Anticancer Res. 2016, 36, 5665-5672, doi:10.21873/anticanres.11149.

63. Fletcher, J.I.; Williams, R.T.; Henderson, M.J.; Norris, M.D.; Haber, M. ABC transporters as mediators of drug resistance and contributors to cancer cell biology. Drug Resist. Updat. 2016, 26, 1-9, doi:10.1016/j.drup.2016.03.001.

64. Kathawala, R.J.; Gupta, P.; Ashby, C.R.; Chen, Z.-S. The modulation of ABC transportermediated multidrug resistance in cancer: a review of the past decade. Drug Resist. Updat. 2015, 18, 1-17, doi:10.1016/j.drup.2014.11.002.

65. Robey, R.W.; Pluchino, K.M.; Hall, M.D.; Fojo, A.T.; Bates, S.E.; Gottesman, M.M. Revisiting the role of $\mathrm{ABC}$ transporters in multidrug-resistant cancer. Nat. Rev. Cancer 2018, 18, 452-464, doi:10.1038/s41568-018-0005-8.

66. Locher, K.P. Mechanistic diversity in ATP-binding cassette (ABC) transporters. Nat. Struct. Mol. Biol. 2016, 23, 487-493, doi:10.1038/nsmb.3216.

67. Vetrivel, U.; Subramanian, G. Importance of ABC transporters in different tissues. Drug Metabol. Drug Interact. 2014, 29, 65-66, doi:10.1515/dmdi-2014-0016.

68. Leonard, G.D.; Fojo, T.; Bates, S.E. The role of ABC transporters in clinical practice. The Oncologist 2003, 8, 411-424.

69. Kovalev, A.A.; Tsvetaeva, D.A.; Grudinskaja, T.V. Role of ABC-cassette transporters (MDR1, MRP1, BCRP) in the development of primary and acquired multiple drug resistance in patients with early and metastatic breast cancer. Exp. Oncol. 2013, 35, 287290.

70. Ferreira, R.J.; dos Santos, D.J.; Ferreira, M.-J.U. P-glycoprotein and membrane roles in multidrug resistance. Future Med. Chem. 2015, 7, 929-946, doi:10.4155/fmc.15.36.

71. Haimeur, A.; Conseil, G.; Deeley, R.G.; Cole, S.P.C. The MRP-related and BCRP/ABCG2 multidrug resistance proteins: biology, substrate specificity and regulation. Curr. Drug Metab. 2004, 5, 21-53.

72. Saneja, A.; Khare, V.; Alam, N.; Dubey, R.D.; Gupta, P.N. Advances in P-glycoproteinbased approaches for delivering anticancer drugs: pharmacokinetic perspective and clinical relevance. Expert Opin. Drug Deliv. 2014, 11, 121-138, doi:10.1517/17425247.2014.865014.

73. P. Tegos, G.; Haynes, M.; Jacob Strouse, J.; Md. T. Khan, M.; G. Bologa, C.; I. Oprea, T.; A. Sklar, L. Microbial Efflux Pump Inhibition: Tactics and Strategies. Curr. Pharm. Des. 2011, 17, 1291-1302, doi:10.2174/138161211795703726. 
74. Akhtar, N.; Ahad, A.; Khar, R.K.; Jaggi, M.; Aqil, M.; Iqbal, Z.; Ahmad, F.J.; Talegaonkar, $\mathrm{S}$. The emerging role of P-glycoprotein inhibitors in drug delivery: a patent review. Expert Opin. Ther. Pat. 2011, 21, 561-576, doi:10.1517/13543776.2011.561784.

75. Spengler, G.; Evaristo, M.; Handzlik, J.; Serly, J.; Molnár, J.; Viveiros, M.; KiécKononowicz, K.; Amaral, L. Biological activity of hydantoin derivatives on P-glycoprotein (ABCB1) of mouse lymphoma cells. Anticancer Res. 2010, 30, 4867-4871.

76. Ghaleb, H.; Li, H.; Kairuki, M.; Qiu, Q.; Bi, X.; Liu, C.; Liao, C.; Li, J.; Hezam, K.; Huang, $\mathrm{W}$; et al. Design, synthesis and evaluation of a novel series of inhibitors reversing Pglycoprotein-mediated multidrug resistance. Chem. Biol. Drug Des. 2018, 92, 1708-1716, doi:10.1111/cbdd.13338.

77. Ferreira, R.J.; Bonito, C.A.; Ferreira, M.J.U.; Santos, D.J.V.A. dos About P-glycoprotein: a new drugable domain is emerging from structural data. WIREs Comput Mol Sci 2017, 7, doi:10.1002/wcms.1316.

78. Werle, M.; Takeuchi, H.; Bernkop-Schnürch, A. New-generation efflux pump inhibitors. Expert Rev. Clin. Pharmacol. 2008, 1, 429-440, doi:10.1586/17512433.1.3.429.

79. Amaral, L.; Spengler, G.; Martins, A.; Armada, A.; Handzlik, J.; Kiec-Kononowicz, K.; Molnar, J. Inhibitors of Bacterial Efflux Pumps that also Inhibit Efflux Pumps of Cancer Cells. Anticancer Res. 2012, 32, 2947-2957.

80. Amaral, L.; Engi, H.; Viveiros, M.; Molnar, J. Review. Comparison of multidrug resistant efflux pumps of cancer and bacterial cells with respect to the same inhibitory agents. In Vivo 2007, 21, 237-244.

81. Dheyab, H.H.; Muhi-eldeen, Z.; Abdelmalek, S.M.A. The mammalian efflux pump inhibitor Valspodar (PSC833) improves susceptibility of MRSA to antibiotics. Int. Arab. J. Antimicrob. Agents 2016, 6.

82. Pusztai, L.; Wagner, P.; Ibrahim, N.; Rivera, E.; Theriault, R.; Booser, D.; Symmans, F.W.; Wong, F.; Blumenschein, G.; Fleming, D.R.; et al. Phase II study of tariquidar, a selective P-glycoprotein inhibitor, in patients with chemotherapy-resistant, advanced breast carcinoma. Cancer 2005, 104, 682-691, doi:10.1002/cncr.21227.

83. Zuylen, L. van; Sparreboom, A.; Gaast, A. van der; Burg, M.E.L. van der; Beurden, V. van; Bol, C.J.; Woestenborghs, R.; Palmer, P.A.; Verweij, J. The Orally Administered Pglycoprotein Inhibitor R101933 Does Not Alter the Plasma Pharmacokinetics of Docetaxel. Clin. Cancer Res. 2000, 6, 1365-1371.

84. Fox, E.; Widemann, B.C.; Pastakia, D.; Chen, C.C.; Yang, S.X.; Cole, D.; Balis, F.M. Pharmacokinetic and pharmacodynamic study of tariquidar (XR9576), a P-glycoprotein inhibitor, in combination with doxorubicin, vinorelbine, or docetaxel in children and adolescents with refractory solid tumors. Cancer Chemother. Pharmacol. 2015, 76, 12731283, doi:10.1007/s00280-015-2845-1.

85. Kelly, R.J.; Draper, D.; Chen, C.C.; Robey, R.W.; Figg, W.D.; Piekarz, R.L.; Chen, X.; Gardner, E.R.; Balis, F.M.; Venkatesan, A.M.; et al. A pharmacodynamic study of docetaxel in combination with the P-glycoprotein antagonist tariquidar (XR9576) in patients with lung, ovarian, and cervical cancer. Clin. Cancer Res. 2011, 17, 569-580, doi:10.1158/1078-0432.CCR-10-1725.

86. Rubin, E.H.; de Alwis, D.P.; Pouliquen, I.; Green, L.; Marder, P.; Lin, Y.; Musanti, R.; Grospe, S.L.; Smith, S.L.; Toppmeyer, D.L.; et al. A phase I trial of a potent P-glycoprotein inhibitor, Zosuquidar.3HCl trihydrochloride (LY335979), administered orally in combination with doxorubicin in patients with advanced malignancies. Clin. Cancer Res. Off. J. Am. Assoc. Cancer Res. 2002, 8, 3710-3717.

87. Callaghan, R.; Luk, F.; Bebawy, M. Inhibition of the Multidrug Resistance P-Glycoprotein: Time for a Change of Strategy? Drug Metab. Dispos. 2014, 42, 623-631, doi:10.1124/dmd.113.056176. 
88. Amin, M.L. P-glycoprotein Inhibition for Optimal Drug Delivery. Drug Target Insights 2013, 7, 27-34, doi:10.4137/DTI.S12519.

89. Weinstein, G.D.; McCullough, J.L.; Ross, P. Cell proliferation in normal epidermis. J. Invest. Dermatol. 1984, 82, 623-628.

90. Fabrikant, J.I.; Cherry, J. The kinetics of cellular proliferation in normal and malignant tissues. V. Analysis of labeling indices and potential tissue doubling times in human tumor cell populations. J. Surg. Oncol. 2006, 1, 23-47, doi:10.1002/jso.2930010106.

91. Kastan, M.B.; Bartek, J. Cell-cycle checkpoints and cancer. Nature 2004, 432, 316-323, doi:10.1038/nature03097.

92. Tamaki, S.; Tokumoto, Y. Overexpression of cyclin dependent kinase inhibitor P27/Kip1 increases oligodendrocyte differentiation from induced pluripotent stem cells. In Vitro Cell. Dev. Biol. Anim. 2014, 50, 778-785, doi:10.1007/s11626-014-9753-2.

93. Mirza-Aghazadeh-Attari, M.; Darband, S.G.; Kaviani, M.; Mihanfar, A.; Aghazadeh Attari, J.; Yousefi, B.; Majidinia, M. DNA damage response and repair in colorectal cancer: Defects, regulation and therapeutic implications. DNA Repair 2018, 69, 34-52, doi:10.1016/j.dnarep.2018.07.005.

94. Hengartner, M.O. The biochemistry of apoptosis. Nature 2000, 407, 770-776, doi:10.1038/35037710.

95. Hassan, M.; Watari, H.; AbuAlmaaty, A.; Ohba, Y.; Sakuragi, N. Apoptosis and molecular targeting therapy in cancer. BioMed Res. Int. 2014, 2014, 150845, doi:10.1155/2014/150845.

96. Elmore, S. Apoptosis: a review of programmed cell death. Toxicol. Pathol. 2007, 35, 495516, doi:10.1080/01926230701320337.

97. Wong, R.S. Apoptosis in cancer: from pathogenesis to treatment. J. Exp. Clin. Cancer Res. 2011, 30, 87, doi:10.1186/1756-9966-30-87.

98. Xu, D.C.; Arthurton, L.; Baena-Lopez, L.A. Learning on the Fly: The Interplay between Caspases and Cancer. BioMed Res. Int. 2018, 2018, 5473180, doi:10.1155/2018/5473180.

99. Chung, C. Restoring the switch for cancer cell death: Targeting the apoptosis signaling pathway. Am. J. Health Syst. Pharm. 2018, 75, 945-952, doi:10.2146/ajhp170607.

100. Fink, S.L.; Cookson, B.T. Apoptosis, Pyroptosis, and Necrosis: Mechanistic Description of Dead and Dying Eukaryotic Cells. Infect. Immun. 2005, 73, 1907-1916, doi:10.1128/IAI.73.4.1907-1916.2005.

101. Gonzalez, V.M.; Fuertes, M.A.; Alonso, C.; Perez, J.M. Is cisplatin-induced cell death always produced by apoptosis? Mol. Pharmacol. 2001, 59, 657-663.

102. Ouyang, L.; Shi, Z.; Zhao, S.; Wang, F.-T.; Zhou, T.-T.; Liu, B.; Bao, J.-K. Programmed cell death pathways in cancer: a review of apoptosis, autophagy and programmed necrosis. Cell Prolif. 2012, 45, 487-498, doi:10.1111/j.1365-2184.2012.00845.x.

103. Patel, V.A.; Longacre, A.; Hsiao, K.; Fan, H.; Meng, F.; Mitchell, J.E.; Rauch, J.; Ucker, D.S.; Levine, J.S. Apoptotic Cells, at All Stages of the Death Process, Trigger Characteristic Signaling Events That Are Divergent from and Dominant over Those Triggered by Necrotic Cells. J. Biol. Chem. 2006, 281, 4663-4670, doi:10.1074/jbc.M508342200.

104. Dodig, S.; Cepelak, I. The facts and controversies about selenium. Acta Pharm. 2004, 54, 261-276.

105.ATSDR - Toxicological Profile: Selenium Available online: https://www.atsdr.cdc.gov/toxprofiles/tp.asp?id=153\&tid=28 (accessed on Jul 29, 2018).

106. Levander, O.A.; Beck, M.A. Interacting nutritional and infectious etiologies of Keshan disease. Insights from coxsackie virus B-induced myocarditis in mice deficient in selenium or vitamin E. Biol. Trace Elem. Res. 1997, 56, 5-21, doi:10.1007/BF02778980. 
107. Foster, H.D. The iodine-selenium connection: its possible roles in intelligence, cretinism, sudden infant death syndrome, breast cancer and multiple sclerosis. Med. Hypotheses 1993, $40,61-65$.

108. Hoffmann, P.R.; Berry, M.J. The influence of selenium on immune responses. Mol. Nutr. Food Res. 2008, 52, 1273-1280, doi:10.1002/mnfr.200700330.

109. Pasco, J.A.; Jacka, F.N.; Williams, L.J.; Evans-Cleverdon, M.; Brennan, S.L.; Kotowicz, M.A.; Nicholson, G.C.; Ball, M.J.; Berk, M. Dietary selenium and major depression: a nested case-control study. Complement. Ther. Med. 2012, 20, 119-123, doi:10.1016/j.ctim.2011.12.008.

110. Flores-Mateo, G.; Navas-Acien, A.; Pastor-Barriuso, R.; Guallar, E. Selenium and coronary heart disease: a meta-analysis. Am. J. Clin. Nutr. 2006, 84, 762-773, doi:10.1093/ajcn/84.4.762.

111. Fernandes, A.P.; Gandin, V. Selenium compounds as therapeutic agents in cancer. Biochim. Biophys. Acta 2015, 1850, 1642-1660, doi:10.1016/j.bbagen.2014.10.008.

112. Norton, R.L.; Hoffmann, P.R. Selenium and asthma. Mol. Aspects Med. 2012, 33, 98-106, doi:10.1016/j.mam.2011.10.003.

113. Rayman, M.P. The importance of selenium to human health. Lancet 2000, 356, 233-241, doi:10.1016/S0140-6736(00)02490-9.

114. Rayman, M.P. Selenium and human health. Lancet 2012, 379, 1256-1268, doi:10.1016/S0140-6736(11)61452-9.

115. Turanov, A.A.; Xu, X.-M.; Carlson, B.A.; Yoo, M.-H.; Gladyshev, V.N.; Hatfield, D.L. Biosynthesis of selenocysteine, the 21 st amino acid in the genetic code, and a novel pathway for cysteine biosynthesis. Adv. Nutr. 2011, 2, 122-128, doi:10.3945/an.110.000265.

116. Schrauzer, G.N. The nutritional significance, metabolism and toxicology of selenomethionine. Adv. Food Nutr. Res. 2003, 47, 73-112.

117. Ramoutar, R.R.; Brumaghim, J.L. Antioxidant and anticancer properties and mechanisms of inorganic selenium, oxo-sulfur, and oxo-selenium compounds. Cell Biochem. Biophys. 2010, 58, 1-23, doi:10.1007/s12013-010-9088-x.

118. Clark, L.C.; Dalkin, B.; Krongrad, A.; Combs, G.F.; Turnbull, B.W.; Slate, E.H.; Witherington, R.; Herlong, J.H.; Janosko, E.; Carpenter, D.; et al. Decreased incidence of prostate cancer with selenium supplementation: results of a double-blind cancer prevention trial. Br. J. Urol. 1998, 81, 730-734.

119. Estevam, E.C.; Witek, K.; Faulstich, L.; Nasim, M.J.; Latacz, G.; Domínguez-Álvarez, E.; Kieć-Kononowicz, K.; Demasi, M.; Handzlik, J.; Jacob, C. Aspects of a Distinct Cytotoxicity of Selenium Salts and Organic Selenides in Living Cells with Possible Implications for Drug Design. Molecules (Basel) 2015, 20, 13894-13912, doi:10.3390/molecules200813894.

120. Navarro Silvera, S.A.; Rohan, T.E. Trace elements and cancer risk: a review of the epidemiologic evidence. Cancer Causes Control 2007, 18, 7-27, doi:10.1007/s 10552-0060057-z.

121. Reid, M.E.; Duffield-Lillico, A.J.; Slate, E.; Natarajan, N.; Turnbull, B.; Jacobs, E.; Combs, G.F.; Alberts, D.S.; Clark, L.C.; Marshall, J.R. The nutritional prevention of cancer: $400 \mathrm{mcg}$ per day selenium treatment. Nutr. Cancer 2008, 60, 155-163, doi:10.1080/01635580701684856.

122. Klein, E.A.; Thompson, I.M.; Lippman, S.M.; Goodman, P.J.; Albanes, D.; Taylor, P.R.; Coltman, C. SELECT: the Selenium and Vitamin E Cancer Prevention Trial: rationale and design. Prostatic Dis. 2000, 3, 145-151, doi:10.1038/sj.pcan.4500412.

123. Klein, E.A.; Thompson, I.M.; Tangen, C.M.; Crowley, J.J.; Lucia, M.S.; Goodman, P.J.; Minasian, L.M.; Ford, L.G.; Parnes, H.L.; Gaziano, J.M.; et al. Vitamin E and the risk of 
prostate cancer: the Selenium and Vitamin E Cancer Prevention Trial (SELECT). JAMA 2011, 306, 1549-1556, doi:10.1001/jama.2011.1437.

124. Li, J.Y.; Taylor, P.R.; Li, B.; Dawsey, S.; Wang, G.Q.; Ershow, A.G.; Guo, W.; Liu, S.F.; Yang, C.S.; Shen, Q. Nutrition intervention trials in Linxian, China: multiple vitamin/mineral supplementation, cancer incidence, and disease-specific mortality among adults with esophageal dysplasia. J. Natl. Cancer Inst. 1993, 85, 1492-1498.

125. Yu, S.-Y.; Ya-Jun-Zhu; Li, W.-G.; Huang, Q.-S.; Zhi-Huang, C.; Qi-Nan-Zhang; Hou, C. A preliminary report on the intervention trials of primary liver cancer in high-risk populations with nutritional supplementation of selenium in China. Biol. Trace Elem. Res. 1991, 29, 289-294, doi:10.1007/BF03032685.

126. Faubert, B.; Li, K.Y.; Cai, L.; Hensley, C.T.; Kim, J.; Zacharias, L.G.; Yang, C.; Do, Q.N.; Doucette, S.; Burguete, D.; et al. Lactate Metabolism in Human Lung Tumors. Cell 2017, 171, 358-371.e9, doi:10.1016/j.cell.2017.09.019.

127. Jacob, C. Redox signalling via the cellular thiolstat. Biochem. Soc. Trans. 2011, 39, 12471253, doi:10.1042/BST0391247.

128. Giles, N.M.; Giles, G.I.; Holley, J.E.; Gutowski, N.J.; Jacob, C. Targeting oxidative stressrelated diseases: organochalcogen catalysts as redox sensitizers. Biochem. Pharmacol. 2003, 66, 2021-2028.

129. Jamier, V.; Ba, L.A.; Jacob, C. Selenium- and tellurium-containing multifunctional redox agents as biochemical redox modulators with selective cytotoxicity. Chem-Eur J 2010, 16, 10920-10928, doi:10.1002/chem.201000884.

130. Heiden, M.G.V.; Cantley, L.C.; Thompson, C.B. Understanding the Warburg Effect: The Metabolic Requirements of Cell Proliferation. Science 2009, 324, 1029-1033, doi:10.1126/science.1160809.

131. Liberti, M.V.; Locasale, J.W. The Warburg Effect: How Does it Benefit Cancer Cells? Trends Biochem. Sci. 2016, 41, 211-218, doi:10.1016/j.tibs.2015.12.001.

132. Combs, G.F.; Gray, W.P. Chemopreventive agents: selenium. Pharmacol. Ther. 1998, 79, 179-192.

133. Molavian, H.R.; Goldman, A.; Phipps, C.J.; Kohandel, M.; Wouters, B.G.; Sengupta, S.; Sivaloganathan, S. Drug-induced reactive oxygen species (ROS) rely on cell membrane properties to exert anticancer effects. Sci. Rep. 2016, 6, 27439, doi:10.1038/srep27439.

134. Briehl, M.M.; Tome, M.E.; Wilkinson, S.T.; Jaramillo, M.C.; Lee, K. Mitochondria and redox homeostasis as chemotherapeutic targets. Biochem. Soc. Trans. 2014, 42, 939-944, doi:10.1042/BST20140087.

135. Mániková, D.; Letavayová, L.M.; Vlasáková, D.; Košík, P.; Estevam, E.C.; Nasim, M.J.; Gruhlke, M.; Slusarenko, A.; Burkholz, T.; Jacob, C.; et al. Intracellular diagnostics: hunting for the mode of action of redox-modulating selenium compounds in selected model systems. Molecules (Basel) 2014, 19, 12258-12279, doi:10.3390/molecules190812258.

136. Misra, S.; Boylan, M.; Selvam, A.; Spallholz, J.E.; Björnstedt, M. Redox-active selenium compounds--from toxicity and cell death to cancer treatment. Nutrients 2015, 7, 35363556, doi:10.3390/nu7053536.

137. Mecklenburg, S.; Shaaban, S.; Ba, L.A.; Burkholz, T.; Schneider, T.; Diesel, B.; Kiemer, A.K.; Röseler, A.; Becker, K.; Reichrath, J.; et al. Exploring synthetic avenues for the effective synthesis of selenium- and tellurium-containing multifunctional redox agents. Org. Biomol. Chem. 2009, 7, 4753-4762, doi:10.1039/b907831b.

138. Brozmanová, J.; Mániková, D.; Vlčková, V.; Chovanec, M. Selenium: a double-edged sword for defense and offence in cancer. Arch. Toxicol. 2010, 84, 919-938, doi:10.1007/s00204-010-0595-8.

139. Nasim, M.J.; Ali, W.; Domínguez-Álvarez, E.; Júnior, E.N. da S.; Saleem, R.S.Z.; Jacob, C. Chapter 10:Reactive Selenium Species: Redox Modulation, Antioxidant, Antimicrobial 
and Anticancer Activities. In Organoselenium Compounds in Biology and Medicine; 2017; pp. 277-302.

140. Witek, K.; Nasim, M.J.; Bischoff, M.; Gaupp, R.; Arsenyan, P.; Vasiljeva, J.; Marć, M.A.; Olejarz, A.; Latacz, G.; Kieć-Kononowicz, K.; et al. Selenazolinium Salts as "Small Molecule Catalysts" with High Potency against ESKAPE Bacterial Pathogens. Molecules (Basel) 2017, 22, doi:10.3390/molecules22122174.

141. Abdulah, R.; Miyazaki, K.; Nakazawa, M.; Koyama, H. Chemical forms of selenium for cancer prevention. J. Trace Elem. 2005, 19, 141-150, doi:10.1016/j.jtemb.2005.09.003.

142. Qi, Y.; Fu, X.; Xiong, Z.; Zhang, H.; Hill, S.M.; Rowan, B.G.; Dong, Y. Methylseleninic acid enhances paclitaxel efficacy for the treatment of triple-negative breast cancer. Plos One 2012, 7, e31539, doi:10.1371/journal.pone.0031539.

143. Álvarez-Pérez, M.; Ali, W.; Marć, M.A.; Handzlik, J.; Domínguez-Álvarez, E. Selenides and Diselenides: A Review of Their Anticancer and Chemopreventive Activity. Molecules (Basel) 2018, 23, 628, doi:10.3390/molecules23030628.

144. Bartolini, D.; Sancineto, L.; Fabro de Bem, A.; Tew, K.D.; Santi, C.; Radi, R.; Toquato, P.; Galli, F. Selenocompounds in Cancer Therapy: An Overview. Adv. Cancer Res. 2017, 136, 259-302, doi:10.1016/bs.acr.2017.07.007.

145. Menon, S.; Ks, S.D.; R, S.; S, R.; S, V.K. Selenium nanoparticles: A potent chemotherapeutic agent and an elucidation of its mechanism. Colloids Surf. B 2018, 170, 280-292, doi:10.1016/j.colsurfb.2018.06.006.

146. Kunjachan, S.; Rychlik, B.; Storm, G.; Kiessling, F.; Lammers, T. Multidrug resistance: Physiological principles and nanomedical solutions. Adv. Drug Deliv. Rev. 2013, 65, 18521865, doi:10.1016/j.addr.2013.09.018.

147. Sakr, T.M.; Korany, M.; Katti, K.V. Selenium nanomaterials in biomedicine-An overview of new opportunities in nanomedicine of selenium. J. Drug Deliv. Sci. Technol. 2018, 46, 223-233, doi:10.1016/j.jddst.2018.05.023.

148.Wereszczynska-Siemiatkowska, U.; Mroczko, B.; Siemiatkowski, A.; Szmitkowski, M.; Borawska, M.; Kosel, J. The importance of interleukin 18, glutathione peroxidase, and selenium concentration changes in acute pancreatitis. Dig. Dis. Sci. 2004, 49, 642-650.

149. Song, H.; Kim, J.; Lee, H.-K.; Park, H.; Nam, J.; Park, G.B.; Kim, Y.S.; Cho, D.; Hur, D.Y. Selenium inhibits migration of murine melanoma cells via down-modulation of IL-18 expression. Int. Immunopharmacol. 2011, 11, 2208-2213, doi:10.1016/j.intimp.2011.10.002.

150. Chen, Y.-C.; Prabhu, K.S.; Mastro, A.M. Is selenium a potential treatment for cancer metastasis? Nutrients 2013, 5, 1149-1168, doi:10.3390/nu5041149.

151. Li, M.; Yu, X. The role of poly(ADP-ribosyl)ation in DNA damage response and cancer chemotherapy. Oncogene 2015, 34, 3349-3356, doi:10.1038/onc.2014.295.

152. Morales, J.C.; Li, L.; Fattah, F.J.; Dong, Y.; Bey, E.A.; Patel, M.; Gao, J.; Boothman, D.A. Review of Poly (ADP-ribose) Polymerase (PARP) Mechanisms of Action and Rationale for Targeting in Cancer and Other Diseases. Crit. Rev. Eukaryot. Gene Expr. 2014, 24, 15 28.

153. Jackson, M.I.; Combs, G.F. Selenium and anticarcinogenesis: underlying mechanisms. Curr. Opin. Clin. Nutr. Metab. Care 2008, 11, 718-726, doi:10.1097/MCO.0b013e3283139674.

154. Domínguez-Álvarez, E.; Plano, D.; Font, M.; Calvo, A.; Prior, C.; Jacob, C.; Palop, J.A.; Sanmartín, C. Synthesis and antiproliferative activity of novel selenoester derivatives. Eur. J. Med. Chem. 2014, 73, 153-166, doi:10.1016/j.ejmech.2013.11.034.

155. Sanmartin, C.; Plano, D.; Font, M.; Palop, J.A. Selenium and clinical trials: new therapeutic evidence for multiple diseases. Curr. Med. Chem. 2011, 18, 4635-4650. 
156. Sanmartín, C.; Plano, D.; Domínguez, E.; Font, M.; Calvo, A.; Prior, C.; Encío, I.; Palop, J.A. Synthesis and Pharmacological Screening of Several Aroyl and Heteroaroyl Selenylacetic Acid Derivatives as Cytotoxic and Antiproliferative Agents. Molecules 2009, 14, 3313-3338, doi:10.3390/molecules 14093313.

157. Cornwell, M.M.; Pastan, I.; Gottesman, M.M. Certain calcium channel blockers bind specifically to multidrug-resistant human $\mathrm{KB}$ carcinoma membrane vesicles and inhibit drug binding to P-glycoprotein. J. Biol. Chem. 1987, 262, 2166-2170.

158. Stockert, J.C.; Blázquez-Castro, A.; Cañete, M.; Horobin, R.W.; Villanueva, Á. MTT assay for cell viability: Intracellular localization of the formazan product is in lipid droplets. Acta Histochem. 2012, 114, 785-796, doi:10.1016/j.acthis.2012.01.006.

159. Acton, E.M.; Narayanan, V.L.; Risbood, P.A.; Shoemaker, R.H.; Vistica, D.T.; Boyd, M.R. Anticancer specificity of some ellipticinium salts against human brain tumors in vitro. J. Med. Chem. 1994, 37, 2185-2189.

160. Spengler, G.; Takács, D.; Horváth, Á.; Riedl, Z.; Hajós, G.; Amaral, L.; Molnár, J. Multidrug Resistance Reversing Activity of Newly Developed Phenothiazines on Pglycoprotein (ABCB1)-related Resistance of Mouse T-Lymphoma Cells. Anticancer Res. 2014, 34, 1737-1741.

161. Forster, S.; Thumser, A.E.; Hood, S.R.; Plant, N. Characterization of Rhodamine-123 as a Tracer Dye for Use In In vitro Drug Transport Assays. PLOS ONE 2012, 7, e33253, doi:10.1371/journal.pone.0033253.

162. Logue, S.E.; Elgendy, M.; Martin, S.J. Expression, purification and use of recombinant annexin V for the detection of apoptotic cells. Nat. Protoc. 2009, 4, 1383-1395, doi:10.1038/nprot.2009.143.

163. Koopman, G.; Reutelingsperger, C.P.; Kuijten, G.A.; Keehnen, R.M.; Pals, S.T.; van Oers, M.H. Annexin V for flow cytometric detection of phosphatidylserine expression on B cells undergoing apoptosis. Blood 1994, 84, 1415-1420.

164. Engeland, M. van; Nieland, L.J.W.; Ramaekers, F.C.S.; Schutte, B.; Reutelingsperger, C.P.M. Annexin V-Affinity assay: A review on an apoptosis detection system based on phosphatidylserine exposure. Cytometry 1998, 31, 1-9.

165. Molnar, J.; Mucsi, I.; Nacsa, J.; Hevér, A.; Gyémánt, N.; Hegyes, P.; Kiessig, S.; Gaal, D.; Lage, H.; Varga, A. New Silicon Compounds as Resistance Modifiers against Multidrugresistant Cancer Cells. Anticancer Res. 2004, 7.

166. Mucsi, I.; Varga, A.; Kawase, M.; Motohashi, N.; Molnar, J. Interaction between various resistance modifiers and apoptosis inducer $12 \mathrm{H}$-benzo[alpha]phenothiazine. Anticancer Res. 2002, 22, 2833-2836.

167. Molecular Properties Prediction - Osiris Property Explorer Available online: https://www.organic-chemistry.org/prog/peo/ (accessed on Jul 4, 2018).

168. PreADMET | Prediction of ADME/Tox Available online: https://preadmet.bmdrc.kr/ (accessed on Jul 4, 2018).

169. The PreADME Approach: Web-based program for rapid prediction of physico-chemical, drug absorption and drug-like properties Available online: https://www.researchgate.net/publication/309311638_The_PreADME_Approach_Webbased_program_for_rapid_prediction_of_physico-chemical_drug_absorption_and_druglike_properties (accessed on Jul 4, 2018).

170. Molecular Properties Prediction - Osiris Property Explorer Tutorial Available online: http://www.rdchemicals.com/property-explorer-tutorial.html (accessed on Jul 4, 2018).

171. Lipinski, C.A. Drug-like properties and the causes of poor solubility and poor permeability. J. Pharmacol. Toxicol. Methods 2000, 44, 235-249. 
172. Lipinski, C.A.; Lombardo, F.; Dominy, B.W.; Feeney, P.J. Experimental and computational approaches to estimate solubility and permeability in drug discovery and development settings. Adv. Drug Deliv. Rev. 2001, 46, 3-26.

173. Kasim, N.A.; Whitehouse, M.; Ramachandran, C.; Bermejo, M.; Lennernäs, H.; Hussain, A.S.; Junginger, H.E.; Stavchansky, S.A.; Midha, K.K.; Shah, V.P.; et al. Molecular properties of WHO essential drugs and provisional biopharmaceutical classification. Mol. Pharm. 2004, 1, 85-96.

174. Escobedo-González, R.; Vargas-Requena, C.L.; Moyers-Montoya, E.; Aceves-Hernández, J.M.; Nicolás-Vázquez, M.I.; Miranda-Ruvalcaba, R. In silico Study of the Pharmacologic Properties and Cytotoxicity Pathways in Cancer Cells of Various Indolylquinone Analogues of Perezone. Molecules (Basel) 2017, 22, 1060, doi:10.3390/molecules22071060.

175. Lu, D.; Chambers, P.; Wipf, P.; Xie, X.-Q.; Englert, D.; Weber, S. Lipophilicity Screening of Novel Drug-like Compounds and Comparison to cLogP. J. Chromatogr. A 2012, 1258, 161-167, doi:10.1016/j.chroma.2012.07.078.

176. Daina, A.; Michielin, O.; Zoete, V. SwissADME: a free web tool to evaluate pharmacokinetics, drug-likeness and medicinal chemistry friendliness of small molecules. Sci. Rep. 2017, 7, 42717, doi:10.1038/srep42717.

177. Shityakov, S.; Neuhaus, W.; Dandekar, T.; Förster, C. Analysing molecular polar surface descriptors to predict blood-brain barrier permeation. Int. J. Comput. Biol. Drug Des. 2013, 6, 146-156, doi:10.1504/IJCBDD.2013.052195.

178. Lu, J.J.; Crimin, K.; Goodwin, J.T.; Crivori, P.; Orrenius, C.; Xing, L.; Tandler, P.J.; Vidmar, T.J.; Amore, B.M.; Wilson, A.G.E.; et al. Influence of Molecular Flexibility and Polar Surface Area Metrics on Oral Bioavailability in the Rat. J. Med. Chem. 2004, 47, 6104-6107, doi:10.1021/jm0306529.

179. Clark, D.E. What has polar surface area ever done for drug discovery? Future Med. Chem. 2011, 3, 469-484, doi:10.4155/fmc.11.1.

180. Bohnert, T.; Gan, L.-S. Plasma protein binding: from discovery to development. J. Pharm. Sci. 2013, 102, 2953-2994, doi:10.1002/jps.23614.

181. Bohets, H.; Annaert, P.; Mannens, G.; Van Beijsterveldt, L.; Anciaux, K.; Verboven, P.; Meuldermans, W.; Lavrijsen, K. Strategies for absorption screening in drug discovery and development. Curr. Top. Med. Chem. 2001, 1, 367-383.

182. Artursson, P.; Palm, K.; Luthman, K. Caco-2 monolayers in experimental and theoretical predictions of drug transport. Adv. Drug Deliv. Rev. 2001, 46, 27-43.

183. Zhao, Y.H.; Le, J.; Abraham, M.H.; Hersey, A.; Eddershaw, P.J.; Luscombe, C.N.; Butina, D.; Beck, G.; Sherborne, B.; Cooper, I.; et al. Evaluation of human intestinal absorption data and subsequent derivation of a quantitative structure-activity relationship (QSAR) with the Abraham descriptors. J. Pharm. Sci. 2001, 90, 749-784.

184. Nettleton, D.O.; Einolf, H.J. Assessment of cytochrome p450 enzyme inhibition and inactivation in drug discovery and development. Curr. Top. Med. Chem. 2011, 11, 382403.

185. Bewick, V.; Cheek, L.; Ball, J. Statistics review 7: Correlation and regression. Crit. Care 2003, 7, 451-459.

186. PAST Available online: https://folk.uio.no/ohammer/past/ (accessed on Jul 4, 2018).

187. PAST: Paleontological Statistical Software Package For Education And Data Analysis Available online: https://palaeo-electronica.org/2001_1/past/issue1_01.htm (accessed on Jul 4, 2018).

188. Stavrovskaya, A.A.; Moiseeva, N.I. Non-canonical functions of the cellular transporter Pglycoprotein. Biochem. Mosc. Suppl. Ser. Membr. Cell Biol. 2016, 10, 241-250, doi:10.1134/S1990747816040085. 
189. Valentin, R.; Grabow, S.; Davids, M.S. The rise of apoptosis: targeting apoptosis in hematologic malignancies. Blood 2018, doi:10.1182/blood-2018-02-791350.

190. Jacob, C.; Giles, G.I.; Giles, N.M.; Sies, H. Sulfur and selenium: the role of oxidation state in protein structure and function. Chem-Eur $J$ 2003, 42, 4742-4758, doi:10.1002/anie.200300573.

191. Lea, M.A. Organosulfur compounds and cancer. Adv. Exp. Med. Biol. 1996, 401, 147154.

192. Moriarty, R.M.; Naithani, R.; Surve, B. Organosulfur compounds in cancer chemoprevention. Mini Rev. Med. Chem. 2007, 7, 827-838.

193. Xiao, D.; Pinto, J.T.; Gundersen, G.G.; Weinstein, I.B. Effects of a series of organosulfur compounds on mitotic arrest and induction of apoptosis in colon cancer cells. Mol. Cancer Ther. 2005, 4, 1388-1398, doi:10.1158/1535-7163.MCT-05-0152. 


\section{ACKNOWLEDGEMENTS}

I would like to thank my supervisor, Dr. Gabriella Spengler for the opportunity to work in the Experimental chemotherapy and prophylaxis research group at the Department of Medical Microbiology and Immunobiology. Furthermore, I wish to thank her for the valuable comments, advice and scientific inspiration. The supportive environment created by her considerably contributed to the success of my research.

I would like to express my gratitude to our head of department, Dr. Katalin Burián for the possibility to work in the Department of Medical Microbiology and Immunobiology.

I am extremely grateful to our collaborators Dr. Enrique Domínguez-Álvarez, Prof. Dr. Carmen Sanmartín and Dr. Jadwiga Handzlik for providing the tested compounds which are the subject of this thesis, also for their friendship and professional advice during our work together.

I would like to thank Dr. Imre Ocsovszki for the help with the flow cytometry experiments and Dr. Ádám Szabó Tönki for the help with the apoptosis induction experiments.

I owe a great deal of gratitude to Anikó Vigyikánné Váradi, not only for the excellent technical assistance, but for her friendship, support and kind words during my time in the laboratory. I am also grateful to my colleagues Annamária Kincses and Márta Nové for their friendship and support. I wish to thank all my colleagues and staff members at the Department of Medical Microbiology and Immunobiology.

I would like to acknowledge Professor József Molnár and Professor Leonard Amaral, two renowned experts in the field of research related to bacterial and cancer multidrug resistance.

I am grateful to Prof. Dr. Edit Urbán for the opportunity to use the resources of the Department of Clinical Microbiology, as well as for her support and guidance as my ESCMID Mentor.

I am grateful to Dr. Edit Paulik and Dr. Andrea Szabó for their collaboration and support in my research endeavours unrelated to the subject of this thesis.

I am especially grateful to Dr. Zoltán Bátori and his family for their selfless help and support. Finally, I feel a deep sense of gratitude to my friends and family for their love and support, especially my mother Szilvia, who did everything in her power to see me succeed and to whom this thesis is dedicated to. 


\section{FINANCIAL SUPPORT}

The work on which this thesis was based on was supported by the following organizations and grants:

- Foundation for Cancer Research Szeged

- TÁMOP 4.2.4.A/2-11-1-2012-0001 'National Excellence Program' supported by the European Union and the State of Hungary, co-financed by the European Social Fund

- Márton Áron Talent Programme 2015/16 (financed by the Hungarian Ministry of Foreign Affairs and Trade)

- Márton Áron Research Programme 2016/17 and 2017/18 (financed by the Hungarian Ministry of Foreign Affairs and Trade)

- Talent Scholarship and Excellence List of the University of Szeged (2015: Bronze level; 2016: Silver level; 2017: Silver level; 2018: Talent of the Year)

- New National Excellence Program of the Ministry of Human Capacities (ÚNKP-17-3)

- Travel Award of the Hungarian Society for Microbiology

- ESCMID Mentorship Programme and Summer School Travel Grant (2017/18) 


\section{APPENDIX}

\section{Appendix 1. IUPAC names of the tested compounds}

1: Benzo[c]selenophen-1,3-dione; 2: Dimethyl thiophene-2,5-dicarboselenoate; 3: Dimethyl pyridine-2,6-dicarboselenoate; 4: Dimethyl benzene-1,3-dicarboselenoate; 5: Dimethyl benzene-1,4-dicarboselenoate;

6:

Carbamoylmethyl

benzoselenoate;

7: Methoxycarbonylmethyl 2-chlorobenzoselenoate; 8: Phenoxycarbonylmethyl benzoselenoate; 9: Methoxycarbonylmethyl 4-chlorobenzoselenoate; 10: 3,3-Dimethyl-2oxobutyl 4-chlorobenzoselenoate; 11: 3,3-Dimethyl-2-oxobutyl 3,5-dimethoxybenzoselenoate;

12:

2-Benzofuran-1,3-dione;

13:

Potassium

cyanate;

14: Ammonium thiocyanate; 15: Potassium selenocyanate<smiles>O=C1OC(=O)c2ccccc21</smiles><smiles>O=C(Cl)c1ccccc1C(=O)Cl</smiles><smiles>CCCCCCCC</smiles><smiles>O=C([O-])c1ccccc1C(=O)[Se][Te]</smiles><smiles>[Os][C@@H]1[CH]CC1</smiles><smiles>O=C1[Se]C(=O)c2ccccc21</smiles>

Appendix 2. Synthesis routes for the cyclic selenoanhydride (1) [154]

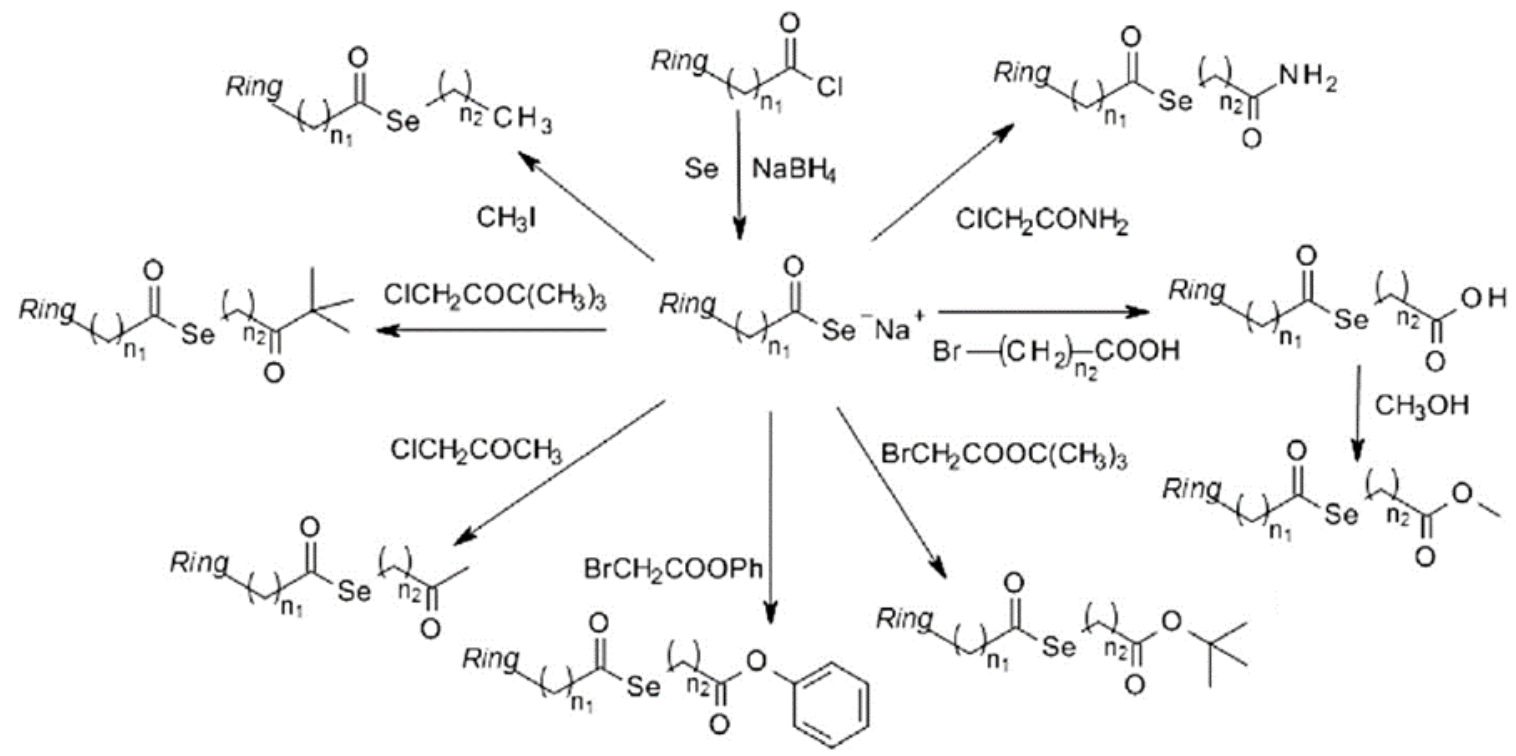

Appendix 3. Synthesis routes for selenoesters 2-11 [154,156] 
<smiles>COC(=O)c1ccccc1-c1c2ccc(=[NH2+])cc-2oc2cc(N)ccc12</smiles>

Appendix 4. Structure of rhodamine 123 (R123) [161]<smiles>c1ccc(Nc2ccccc2Sc2ccccc2)cc1</smiles>

Appendix 5. Structure of M627 (12H-benzo[ $\alpha$ ]phenothiazine) [168]

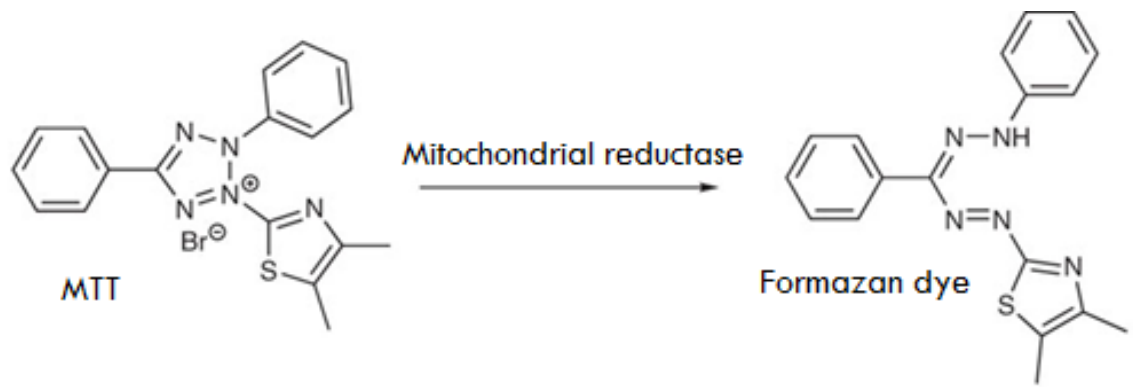

Appendix 6. Molecular basis for the MTT assay [158]

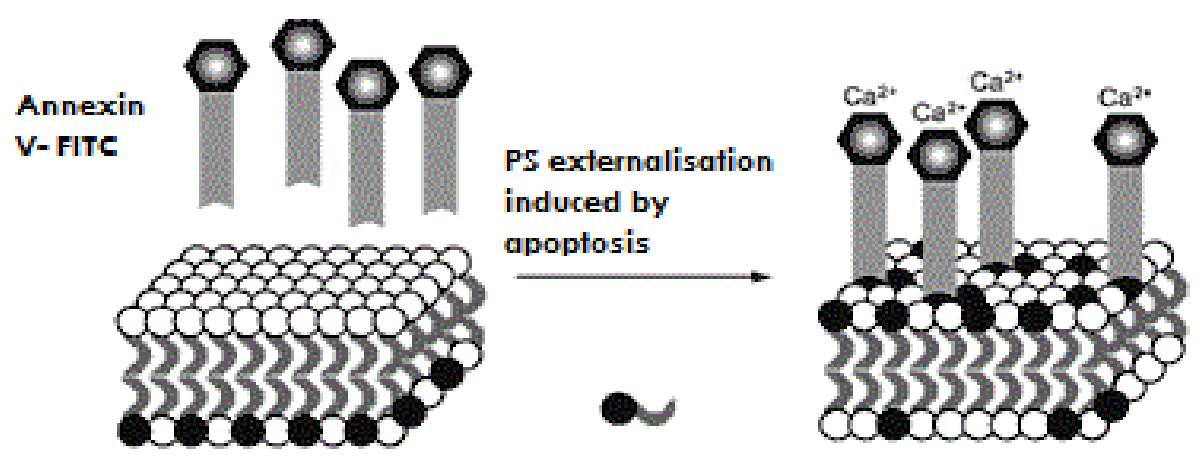

Appendix 7. Phosphatidyl serine externalization occurring after induction of programmed cell death (apoptosis) [165] 


\section{Appendix 8. List of physico-chemical and pharmacokinetic parameters predicted and assessed, evaluation criteria used in predictive in silico assay}

\section{a. Physico-chemical properties}

- Molecular weight (M): based on literature data, potential pharmacological agents with a high molar weight have a higher chance of failing in the clinical trial phase of studies, or their development may even be halted in the pre-clinical phase. More than $80 \%$ of the currently available small molecule pharmacological agents have an $\mathrm{M}<450$, therefore this value was chosen as threshold value.

- Base 10 logarithm of octanol/water partition coefficient $\left(\mathrm{cLogP}=[\mathrm{c}]_{\text {octanol }} /[\mathrm{c}]_{\text {water }}\right)$ : pharmacological molecules, which have inadequate lipophilicity, typically have poor membrane penetration and absorption properties, consequently implying inappropriate bioavailability in vivo. A cLogP value of $<5.0$ was selected as the highest threshold for sufficient lipophilicity.

- Topological polar surface area (TPSA) of the molecules; the polar surface area (PSA) of a molecule consists of the sum of molecular surface attributable to polar atoms (in drug molecules this predominantly means $\mathrm{O}$ and $\mathrm{N}$ atoms and corresponding $\mathrm{H}$ atoms). The precise determination of PSA is expensive and time-consuming, which requires advanced computational tools, while TPSA is an estimated value, which generally correlates well with PSA values. The extent of polar surface area for any given molecule has implications for cell membrane permeability: molecules with TPSA values higher than $140 \AA^{2}(1 \AA$ denotes $10^{-10} \mathrm{~m}$ ) usually have disadvantageous permeability properties. To cross the bloodbrain barrier (BBB) and to reach molecular targets in the central nervous system, the TPSA has to be even smaller $\left(<90 \AA^{2}\right)$.

- Conformity with Lipinsky's Rule of Five (RO5): the rules state that a given biologically active substance is expected to have good oral bioavailability if it does not violate (or violates no more than one of) the following criteria (Rule of Five, RO5): i.) molecular weight has to be $\mathrm{M}<500$, ii) the cLogP value has to be $<5.0$, iii) the overall number of hydrogen bond-donors (predominantly $-\mathrm{OH}$ or $-\mathrm{NH}$ groups) has to be $<5, i v$ ) the overall number of hydrogen bond-acceptors (acceptors can be $\mathrm{O}$ or $\mathrm{N}$ atoms, including the donor groups) has to be <10. The RO5 was formulated by Christopher A. Lipinsky in 1997, based on the observation that most of the drugs with good oral bioavailability are relatively small, moderately lipophilic molecules.

- Base 10 logarithm of water solubility (logS; expressed as mol/L concentration): more, than $80 \%$ of the currently marketed drug molecules have a $\operatorname{logS}$ value $>\mathbf{- 4}$, therefore this value was chosen as reference. 


\section{b. Predicted pharmacokinetic properties}

- Percentage of plasma protein binding (PPB\%): the binding of drug molecules of plasma proteins (serum albumin, lipoproteins and glycoproteins, $\alpha, \beta$ and $\gamma$-globulin) significantly influences the biological half-life and distribution of the given drug. The protein-bound fraction may act as a depot, from which the substance in question is slowly released, so that the free fraction of the drug is metabolized and then complemented by the bound fraction to sustain the biological balance. Plasma protein binding may also play a role in in vivo drug interactions because the bound pharmacological agents with various affinities to the proteins can be compressed to influencing the free/bound concentrations in the body.

- Degree of permeability on Caco-2 human colonic adenocarcinoma and Madin-Darby canine kidney (MDCK) epithelial cell monolayers: several in vitro models have been developed to quantify the intestinal absorption of various drug molecules. Among these models, the Caco-2 (a cell line with high metabolic activity and numerous drug carrier proteins) and MDCK (a cell line with low metabolic activity and transport protein expression) cells have proved to be the most reliable model systems to predict the permeability $[\mathrm{nm} / \mathrm{s}]$ of compounds. Our results were evaluated as follows: low permeability $<4 \mathrm{~nm} / \mathrm{s}$, moderate permeability $4-70 \mathrm{~nm} / \mathrm{s}$ and effective permeability $>70$ $\mathrm{nm} / \mathrm{s}$.

- Degree of human intestinal absorption (HIA\%): the compounds were classified into the following categories based on their estimates HIA\% values: compounds with poor intestinal absorption $0-20 \%$, moderate absorption $20-70 \%$ and excellent absorption 70 $100 \%$.

- Interactions with the cytochrome CYP450 enzymes: the substrate/inhibitor interaction profile of the tested compounds with CYP2D6, CYP2C9 and CYP3A4 enzymes can be evaluated with the use of the PreADMET 2.0. CYP2D6 (inducers, such as dexamethazone, rifampin; inhibitors, such as chloroquin, cimetidine, diltiazem, doxorubicin, moclobemide, vincristine), CYP2C9 (inducers, such as barbiturates, rifampicin; inhibitors, such as apigenine, fluconazole, valproic acid) and CYP3A4 (inducers, such as carbamazepine, phenytoin, rifampicin, phenylbutazone, St. John's Wort; inhibitors, such as amiodarone, cyclosporine A, erythromycin, fluconazole, grapefruit juice, ritonavir, valproic acid) enzymes play a major role in the metabolism of drug molecules for a number of pharmacologically active compounds. 
Appendix 9. Cytotoxic activity and selectivity of the tested compounds against various cell lines of murine origin

\begin{tabular}{|c|c|c|c|c|c|c|c|c|c|}
\hline \multirow{2}{*}{ Compound } & \multicolumn{2}{|c|}{$\begin{array}{c}\text { A: PAR mouse T- } \\
\text { lymphoma }\end{array}$} & \multicolumn{2}{|c|}{$\begin{array}{l}\text { B: MDR mouse T- } \\
\text { lymphoma }\end{array}$} & \multirow{2}{*}{$\begin{array}{c}\text { SI } \\
(\mathbf{A} / \mathbf{B})\end{array}$} & \multicolumn{2}{|c|}{$\begin{array}{c}\text { C: NIH/3T3 mouse } \\
\text { fibroblast }\end{array}$} & \multirow{2}{*}{$\underset{(\mathbf{C} / \mathbf{A})}{\mathbf{S I}}$} & \multirow{2}{*}{$\underset{(\mathbf{C} / \mathbf{B})}{\mathbf{S I}}$} \\
\hline & $\mathrm{IC}_{50}(\boldsymbol{\mu M})$ & $\mathbf{S D} \pm$ & $\mathrm{IC}_{50}(\mu \mathrm{M})$ & $\mathbf{S D} \pm$ & & $\mathrm{IC}_{50}(\mu \mathrm{M})$ & $\mathbf{S D} \pm$ & & \\
\hline 1 & 3.97 & 1.26 & 4.65 & 0.71 & 0.85 & $>100$ & - & $\geq 25.19$ & $\geq 21.51$ \\
\hline 2 & $>100$ & - & $>100$ & - & - & 23.72 & 3.86 & $\leq 0.24$ & $\leq 0.24$ \\
\hline 3 & 19.50 & 2.10 & 16.90 & 3.23 & 1.15 & $>100$ & - & $\geq 5.13$ & $\geq 5.92$ \\
\hline 4 & $>100$ & - & $>100$ & - & - & $>100$ & - & - & - \\
\hline 5 & $>100$ & - & $>100$ & - & - & $>100$ & - & - & - \\
\hline 6 & $>100$ & - & 36.4 & 9.91 & $\geq 2.75$ & 69.69 & 0.34 & $\leq 0.70$ & 1.91 \\
\hline 7 & $>100$ & - & 87.8 & 5.54 & $\geq 1.14$ & 23.72 & 3.86 & $\leq 0.24$ & 0.27 \\
\hline 8 & $>100$ & - & $>100$ & - & - & 74.47 & 2.23 & $\leq 0.74$ & $\leq 0.74$ \\
\hline 9 & 0.78 & 0.17 & 1.03 & 0.31 & 0.76 & 0.62 & 0.13 & 0.79 & 0.61 \\
\hline 10 & 0.94 & 0.11 & 0.43 & 0.25 & 2.19 & 1.35 & 0.01 & 1.44 & 3.14 \\
\hline 11 & 1.31 & 0.12 & 0.97 & 0.28 & 1.35 & 0.82 & 0.06 & 0.63 & 0.85 \\
\hline 12 & $>100$ & - & $>100$ & - & - & $>100$ & - & - & - \\
\hline 13 & $>100$ & - & $>100$ & - & - & $>100$ & - & - & - \\
\hline 14 & $>100$ & - & $>100$ & - & - & $>100$ & - & - & - \\
\hline 15 & $>100$ & - & $>100$ & - & - & $>100$ & - & - & - \\
\hline Cisplatin & 4.87 & 0.58 & 16.65 & 1.02 & 0.29 & 11.16 & 0.08 & 2.29 & 0.67 \\
\hline DMSO & $>2 \mathrm{~V} / \mathrm{V} \%$ & - & $>2 \mathrm{~V} / \mathrm{V} \%$ & - & & $>2 \mathrm{~V} / \mathrm{V} \%$ & - & - & - \\
\hline
\end{tabular}

$\mathrm{IC}_{50}$ : the inhibitory dose that reduces the growth of the cells exposed to the tested compounds by $50 \%$; SD \pm : standard deviation; SI: selectivity index; DMSO: dimethyl sulfoxide 
Appendix 10. Cytotoxic activity and selectivity of the tested compounds against various cell lines of human origin

\begin{tabular}{|c|c|c|c|c|c|c|c|c|c|c|c|c|}
\hline \multirow[t]{2}{*}{ Compound } & \multicolumn{2}{|c|}{$\begin{array}{c}\text { A: Colo } 205 \\
\text { colon } \\
\text { adenocarcinoma }\end{array}$} & \multicolumn{2}{|c|}{$\begin{array}{c}\text { B: Colo } 320 \\
\text { colon } \\
\text { adenocarcinoma }\end{array}$} & \multirow{2}{*}{$\begin{array}{c}\text { SI } \\
(\mathbf{A} / \mathbf{B})\end{array}$} & \multicolumn{2}{|c|}{$\begin{array}{c}\text { C: A549 lung } \\
\text { adenocarcinoma }\end{array}$} & \multicolumn{2}{|c|}{$\begin{array}{l}\text { D: MRC-5 } \\
\text { lung } \\
\text { fibroblast }\end{array}$} & \multirow{2}{*}{$\begin{array}{c}\text { SI } \\
(\mathbf{D} / \mathbf{A})\end{array}$} & \multirow{2}{*}{$\begin{array}{c}\text { SI } \\
(\mathbf{D} / \mathbf{B})\end{array}$} & \multirow{2}{*}{$\begin{array}{c}\text { SI } \\
(\mathrm{D} / \mathrm{C})\end{array}$} \\
\hline & $\mathrm{IC}_{50}(\boldsymbol{\mu M})$ & $\begin{array}{c}\text { SD } \\
\pm \\
\end{array}$ & $\mathrm{IC}_{50}(\boldsymbol{\mu M})$ & $\begin{array}{c}\text { SD } \\
\pm \\
\end{array}$ & & $\mathrm{IC}_{50}(\boldsymbol{\mu M})$ & $\begin{array}{c}\text { SD } \\
\pm\end{array}$ & $\begin{array}{l}\mathrm{IC}_{50} \\
(\mu \mathrm{M})\end{array}$ & $\begin{array}{c}\text { SD } \\
\pm \\
\end{array}$ & & & \\
\hline 1 & $>100$ & - & 63.90 & 2.12 & $\geq 1.6$ & $>100$ & - & $>100$ & - & - & $\geq 1.6$ & - \\
\hline 2 & $>100$ & - & $>100$ & - & - & 49.30 & 3.46 & 4.26 & 0.65 & $\leq 0.04$ & $\leq 0.04$ & 0.09 \\
\hline 3 & $>100$ & - & $>100$ & - & - & $>100$ & - & 17.90 & 0.00 & $\leq 0.18$ & $\leq 0.18$ & $\leq 0.18$ \\
\hline 4 & $>100$ & - & 12.50 & 1.76 & $\geq 8.0$ & $>100$ & - & 28.40 & 0.70 & $\leq 0.28$ & 2.30 & $\leq 0.28$ \\
\hline 5 & $>100$ & - & $>100$ & - & - & $>100$ & - & 61.50 & 2.16 & $\leq 0.62$ & $\leq 0.62$ & $\leq 0.62$ \\
\hline 6 & $>100$ & - & $>100$ & - & - & $>100$ & - & 76.6 & 0.92 & $\leq 0.77$ & $\leq 0.77$ & $\leq 0.77$ \\
\hline 7 & $>100$ & - & $>100$ & - & - & $>100$ & - & 33.40 & 3.08 & $\leq 0.33$ & $\leq 0.33$ & $\leq 0.33$ \\
\hline 8 & $>100$ & - & 53.70 & 0.91 & $\geq 1.90$ & 51.20 & 1.63 & $>100$ & - & - & $\geq 1.9$ & 1.95 \\
\hline 9 & 5.48 & 0.75 & 0.55 & 0.11 & 10.0 & 5.91 & 0.24 & 5.35 & 0.24 & 0.98 & 9.70 & 0.91 \\
\hline 10 & 1.63 & 0.55 & 0.96 & 0.15 & 1.70 & 9.10 & 0.37 & 8.10 & 0.90 & 5.00 & 8.40 & 0.89 \\
\hline 11 & 1.19 & 0.21 & 0.35 & 0.09 & 3.40 & 15.22 & 0.61 & 5.04 & 0.71 & 4.20 & 14.40 & 0.33 \\
\hline 12 & $>100$ & - & $>100$ & - & - & $>100$ & - & $>100$ & - & - & - & - \\
\hline 13 & $>100$ & - & $>100$ & - & - & $>100$ & - & $>100$ & - & - & - & - \\
\hline 14 & $>100$ & - & $>100$ & - & - & $>100$ & - & $>100$ & - & - & - & - \\
\hline 15 & $>100$ & - & $>100$ & - & - & $>100$ & - & $>100$ & - & - & - & - \\
\hline Cisplatin & 62.26 & 1.98 & 37.90 & 4.12 & 1.64 & 3.63 & 0.24 & 33.45 & 2.92 & 0.54 & 0.88 & 9.21 \\
\hline DMSO & $>2 \mathrm{~V} / \mathrm{V} \%$ & - & $>2 \mathrm{~V} / \mathrm{V} \%$ & - & - & $>2$ V/V\% & - & $>2 \mathrm{~V} / \mathrm{V} \%$ & - & - & - & - \\
\hline
\end{tabular}

$\mathrm{IC}_{50}$ : the inhibitory dose that reduces the growth of the cells exposed to the tested compounds by 50\%; SD \pm : standard deviation; SI: selectivity index; DMSO: dimethyl sulfoxide 
Appendix 11. Effects of selenocompounds on rhodamine 123 retention by L5178Y multidrug resistant (MDR) mouse T-lymphoma cells

\begin{tabular}{|c|c|c|c|c|c|c|}
\hline Sample & $\mu \mathrm{M}$ & FSC & SSC & FL-1 & FAR & Quotient (\%) \\
\hline VER & 20 & 1826 & 1357 & 31.20 & 21.29 & 100.00 \\
\hline 1 & 2 & 1761 & 1385 & 63.20 & 43.13 & 202.58 \\
\hline 1 & 20 & 1724 & 1478 & 143.00 & 97.61 & 458.48 \\
\hline 2 & 2 & 2354 & 972 & 1.00 & 0.99 & 4.65 \\
\hline 2 & 20 & 2276 & 960 & 1.09 & 1.07 & 5.03 \\
\hline 3 & 2 & 2277 & 957 & 1.15 & 1.13 & 5.31 \\
\hline 3 & 20 & 2248 & 1001 & 1.51 & 1.49 & 7.00 \\
\hline 4 & 2 & 2323 & 984 & 0.94 & 0.93 & 4.37 \\
\hline 4 & 20 & 2284 & 957 & 0.99 & 0.98 & 4.60 \\
\hline 5 & 2 & 1892 & 1319 & 5.82 & 3.97 & 18.65 \\
\hline 5 & 20 & 1848 & 1378 & 4.52 & 3.09 & 14.51 \\
\hline 6 & 2 & 2302 & 961 & 1.04 & 1.02 & 4.79 \\
\hline 6 & 20 & 2218 & 902 & 1.07 & 1.05 & 4.93 \\
\hline 7 & 2 & 1860 & 1321 & 9.45 & 6.45 & 30.30 \\
\hline 7 & 20 & 1832 & 1351 & 12.00 & 8.53 & 40.07 \\
\hline 8 & 2 & 1855 & 1338 & 0.95 & 0.65 & 3.05 \\
\hline 8 & 20 & 1886 & 1336 & 8.32 & 5.68 & 26.68 \\
\hline 9 & 2 & 1706 & 1406 & 138.00 & 94.19 & 442.41 \\
\hline 9 & 20 & 1755 & 1450 & 124.00 & 84.64 & 397.56 \\
\hline 10 & 2 & 1874 & 1354 & 13.60 & 9.28 & 43.59 \\
\hline 10 & 20 & 1841 & 1326 & 71.30 & 48.67 & 228.62 \\
\hline 11 & 2 & 1824 & 1355 & 18.40 & 12.56 & 58.99 \\
\hline 11 & 20 & 1835 & 1335 & 67.90 & 46.35 & 217.71 \\
\hline 12 & 2 & 1984 & 995 & 0.87 & 0.76 & 3.57 \\
\hline 12 & 20 & 2046 & 1142 & 0.79 & 0.69 & 3.24 \\
\hline 13 & 2 & 2059 & 1017 & 0.72 & 0.61 & 2.87 \\
\hline 13 & 20 & 1886 & 1256 & 0.56 & 0.41 & 1.92 \\
\hline 14 & 2 & 1977 & 1372 & 0.96 & 0.88 & 4.13 \\
\hline 14 & 20 & 1868 & 1050 & 0.72 & 0.61 & 2.87 \\
\hline 15 & 2 & 2013 & 1435 & 0.63 & 0.50 & 2.34 \\
\hline 15 & 20 & 1861 & 1041 & 0.80 & 0.73 & 3.42 \\
\hline DMSO & $2 \mathrm{~V} / \mathrm{V} \%$ & 1932 & 1331 & 1.11 & 0.76 & 3.57 \\
\hline
\end{tabular}

FSC: Forward Scatter Count; SSC: Side Scatter Count; FL-1: Mean fluorescence of the cells; FAR: Fluorescence activity ratio; VER: verapamil 
Appendix 12. Effects of selenocompounds on rhodamine 123 retention by Colo 320 colonic adenocarcinoma cells

\begin{tabular}{|c|c|c|c|c|c|c|}
\hline Sample & $\mu \mathrm{M}$ & FSC & SSC & FL-1 & FAR & Quotient (\%) \\
\hline VER & 20 & 1826 & 1357 & 31.20 & 2.85 & 100.00 \\
\hline 1 & 2 & 1761 & 936 & 17.00 & 3.86 & 135.40 \\
\hline 1 & 20 & 1938 & 985 & 23.00 & 12.30 & 431.90 \\
\hline 2 & 2 & 1912 & 793 & 23.00 & 0.64 & 22.46 \\
\hline 2 & 20 & 1835 & 864 & 1.09 & 0.59 & 20.70 \\
\hline 3 & 2 & 1956 & 761 & 1.15 & 0.55 & 19.30 \\
\hline 3 & 20 & 1794 & 658 & 1.51 & 0.63 & 22.11 \\
\hline 4 & 2 & 1659 & 809 & 0.94 & 0.53 & 18.60 \\
\hline 4 & 20 & 1865 & 854 & 0.99 & 0.68 & 23.86 \\
\hline 5 & 2 & 1895 & 852 & 5.82 & 0.55 & 19.30 \\
\hline 5 & 20 & 1792 & 701 & 4.52 & 0.58 & 20.35 \\
\hline 6 & 2 & 1816 & 776 & 1.04 & 0.60 & 21.05 \\
\hline 6 & 20 & 1890 & 753 & 1.07 & 0.58 & 20.35 \\
\hline 7 & 2 & 1838 & 723 & 9.45 & 0.79 & 27.72 \\
\hline 7 & 20 & 1567 & 687 & 12.00 & 0.75 & 26.32 \\
\hline 8 & 2 & 1588 & 693 & 0.95 & 0.75 & 26.32 \\
\hline 8 & 20 & 1562 & 512 & 8.32 & 1.94 & 68.07 \\
\hline 9 & 2 & 1802 & 1142 & 31.90 & 11.40 & 401.10 \\
\hline 10 & 2 & 2037 & 919 & 24.00 & 6.19 & 217.20 \\
\hline 11 & 2 & 2045 & 929 & 36.70 & 6.49 & 227.70 \\
\hline 12 & 2 & 1984 & 870 & 8.97 & 0.50 & 10.83 \\
\hline 12 & 20 & 1933 & 862 & 8.21 & 0.73 & 15.70 \\
\hline 13 & 2 & 1846 & 887 & 7.16 & 0.76 & 16.49 \\
\hline 13 & 20 & 1879 & 871 & 4.86 & 0.70 & 15.09 \\
\hline 14 & 2 & 1933 & 881 & 10.40 & 0.61 & 13.16 \\
\hline 14 & 20 & 1915 & 871 & 7.15 & 0.41 & 8.93 \\
\hline 15 & 2 & 1946 & 909 & 5.89 & 0.88 & 19.12 \\
\hline 15 & 20 & 2050 & 886 & 8.54 & 0.61 & 13.14 \\
\hline DMSO & $2 \mathrm{~V} / \mathrm{V} \%$ & 1932 & 1331 & 6.92 & 0.59 & 3.57 \\
\hline
\end{tabular}

FSC: Forward Scatter Count; SSC: Side Scatter Count; FL-1: Mean fluorescence of the cells; FAR: Fluorescence activity ratio; VER: verapamil 


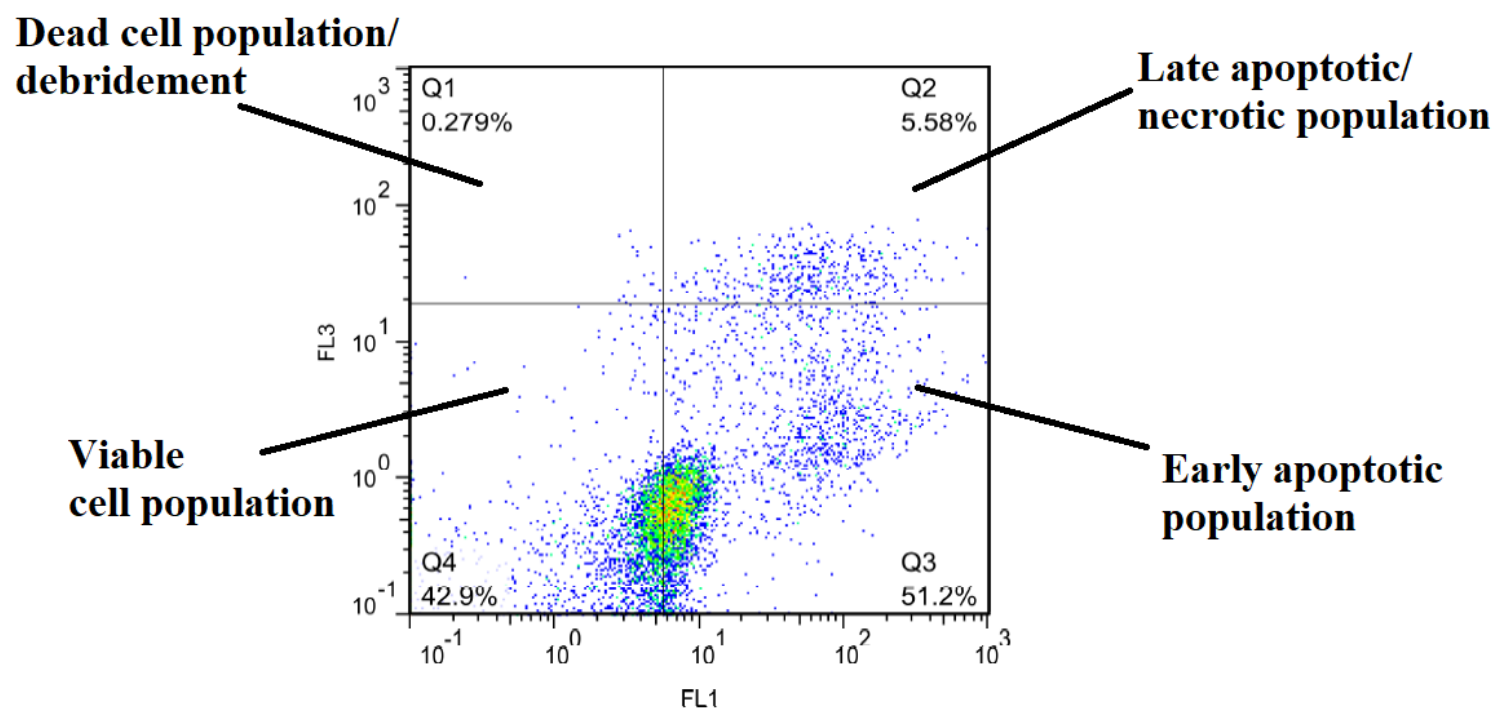

Appendix 13. Interpretation of flow cytometry result diagram (cytogram) for apoptosis induction experiment 


\section{PUBLICATIONS}

